Prepared in cooperation with the

Town of Caroline and Tompkins County Planning Department

Geohydrology and Water Quality of the Valley-Fill Aquifer System in the Upper Sixmile Creek and West Branch Owego Creek Valleys in the Town of Caroline, Tompkins County, New York

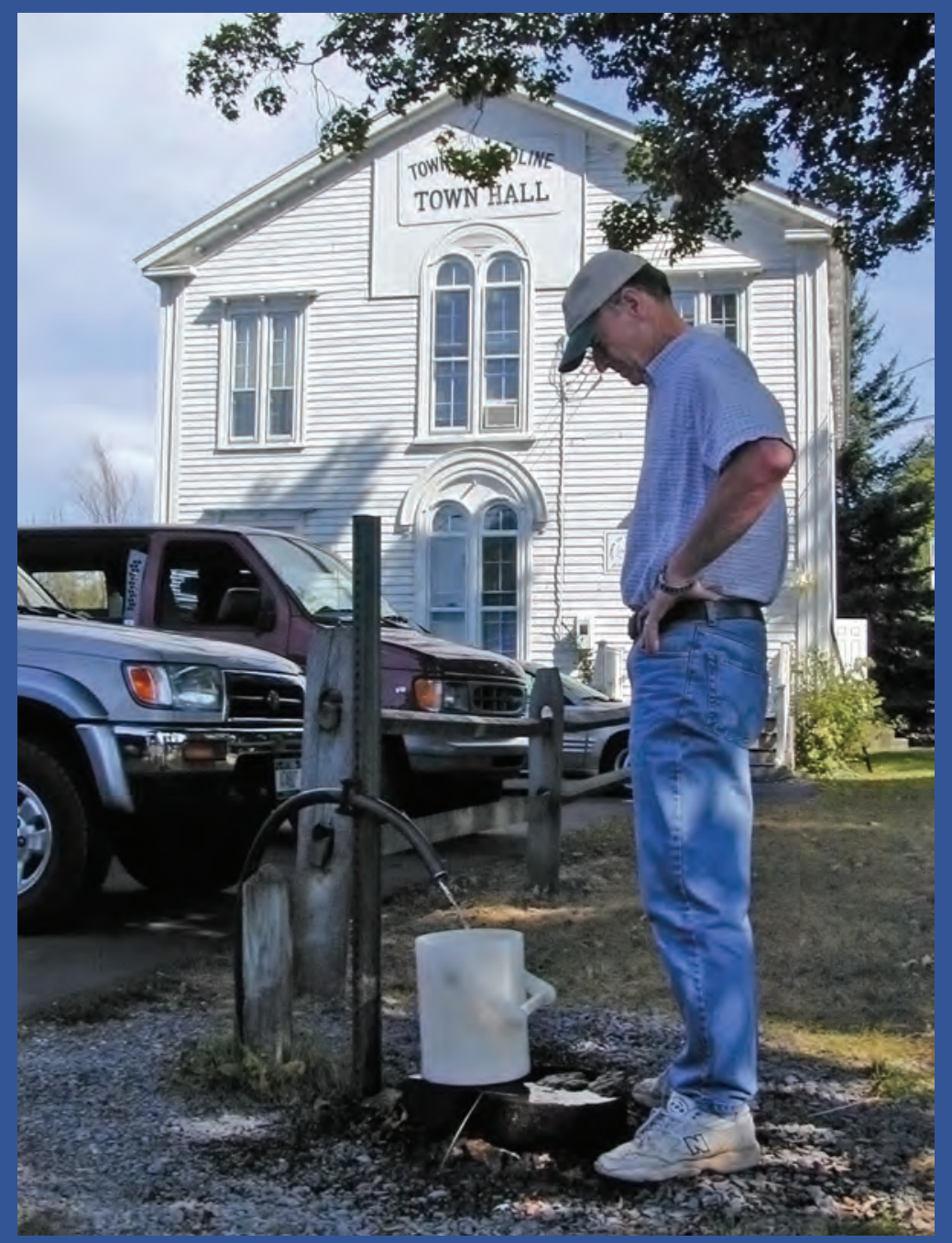

Scientific Investigations Report 2009-5173 
Cover. Donald Sherwood of USGS collecting a groundwater sample from the artesian flowing well at the Town of Caroline, Town Hall, November 30, 2004. 


\section{Geohydrology and Water Quality of the Valley-Fill Aquifer System in the Upper Sixmile Creek and West Branch Owego Creek Valleys in the Town of Caroline, Tompkins County, New York}

By Todd S. Miller

Prepared in cooperation with the

Town of Caroline and Tompkins County Planning Department

Scientific Investigations Report 2009-5173 


\section{U.S. Department of the Interior \\ KEN SALAZAR, Secretary \\ U.S. Geological Survey \\ Marcia K. McNutt, Director}

U.S. Geological Survey, Reston, Virginia: 2009

For more information on the USGS - the Federal source for science about the Earth, its natural and living resources, natural hazards, and the environment, visit http://www.usgs.gov or call 1-888-ASK-USGS

For an overview of USGS information products, including maps, imagery, and publications, visit http://www.usgs.gov/pubprod

To order this and other USGS information products, visit http://store.usgs.gov

Any use of trade, product, or firm names is for descriptive purposes only and does not imply endorsement by the U.S. Government.

Although this report is in the public domain, permission must be secured from the individual copyright owners to reproduce any copyrighted materials contained within this report.

Suggested citation:

Miller, T.S., 2009, Geohydrology and water quality of the valley-fill aquifer system in the upper Sixmile Creek and West Branch Owego Creek valleys in the Town of Caroline, Tompkins County, New York: U.S. Geological Survey Scientific Investigations Report 2009-5173, 56 p. (Also available online at http://pubs.usgs.gov/sir/2009/5173.) 


\section{Contents}

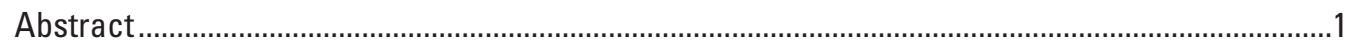

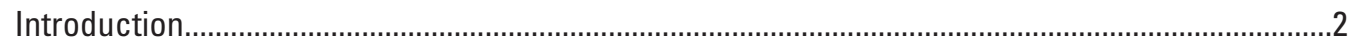

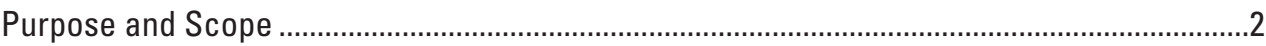

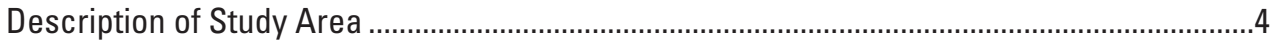

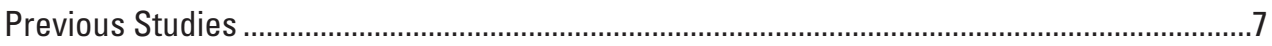

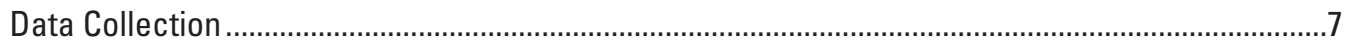

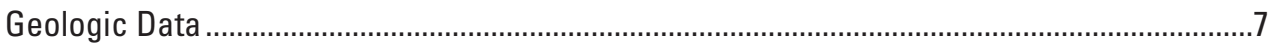

Seismic-Refraction Surveys ...........................................................................................

Well Inventory, Test Drilling, Groundwater-Level and Streamflow Measurements .................7

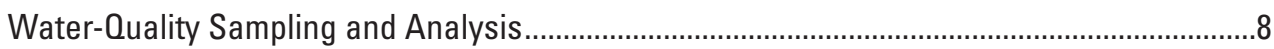

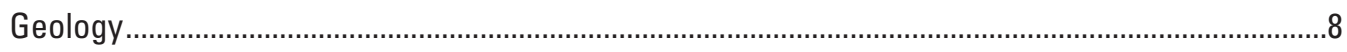

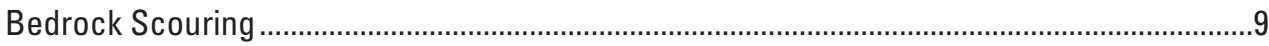

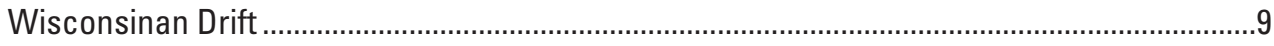

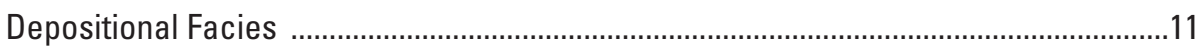

Facies 1-Ice-Contact Deposits ..............................................................................11

Facies 2 —Proglacial Lake Deposits ......................................................................11

Facies 3 - Late- and Post-Glacial Deposits .........................................................13

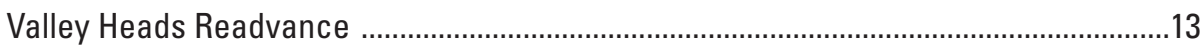

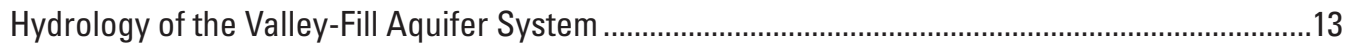

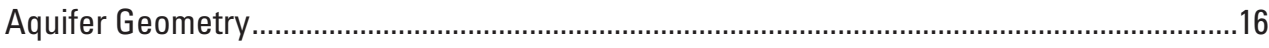

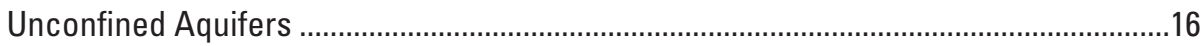

Confined Aquifers and Confining Units .........................................................................19

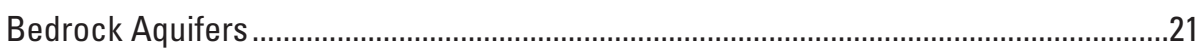

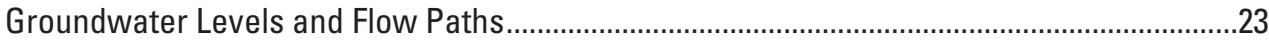

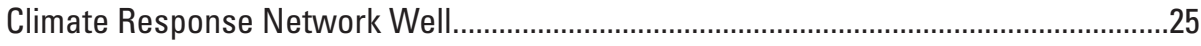

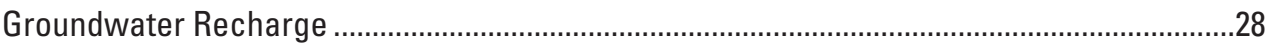

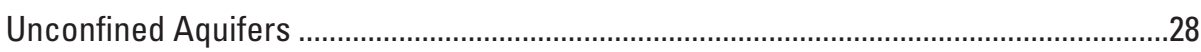

Direct Infiltration of Precipitation on the Valley Floor ............................................28

Unchanneled Runoff and Groundwater Inflow from Adjacent Hillsides .................29

Seepage Losses from Upland Tributaries............................................................29

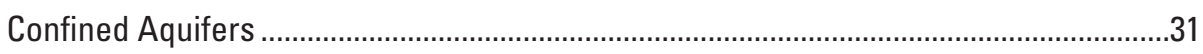

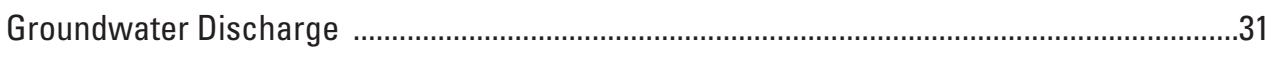

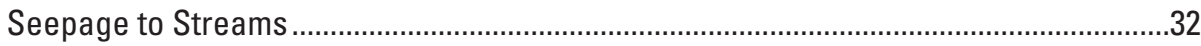

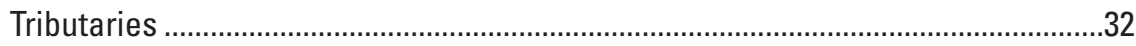

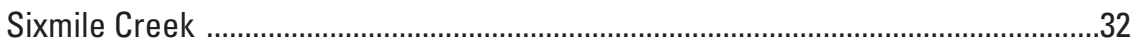

Pumped Withdrawals and Water Availability ................................................................33

Breaching of the Confining Unit at Slaterville Springs ....................................................36

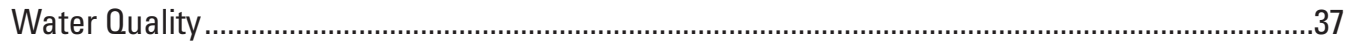

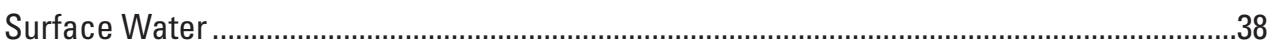

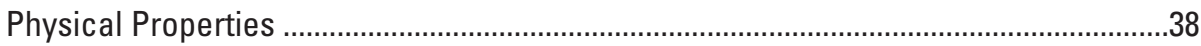

Common Inorganic Constituents ...................................................................................

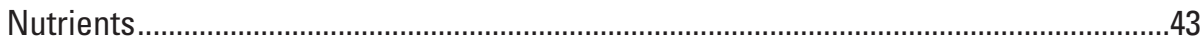


Groundwater

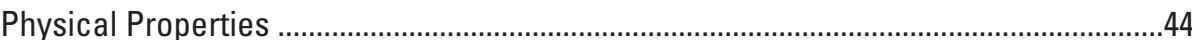

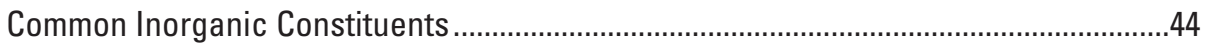

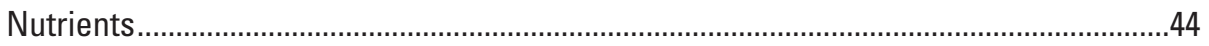

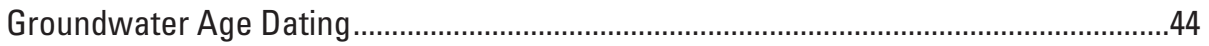

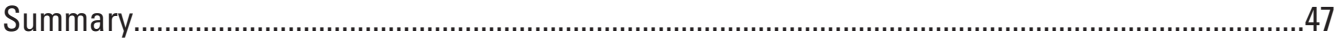

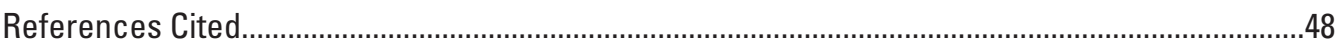

Appendix 1. Records of selected wells in upper Sixmile Creek valley and part of West

Branch Owego Creek valley, Town of Caroline, New York...................................................51

\section{Figures}

1. Map showing location of seventeen unconsolidated aquifer reaches in Tompkins County, New York.

2. Map showing physiographic features and location of upper Sixmile Creek valley and West Branch Owego Creek valley study area in Tompkins County, New York...........4

3. Map showing location of lower Sixmile Creek basin, and the valley-fill aquifer extending across the upper Sixmile Creek basin and in the headwaters of West Branch Owego Creek basin, Town of Caroline, New York

4. Map showing shaded relief and boundary of valley-fill aquifer in the upper Sixmile Creek valley and the headwaters of West Branch Owego Creek valley, Town of Caroline, New York

5. Map showing surficial geology of the valley-fill aquifer in upper Sixmile Creek valley and part of West Branch Owego Creek valley, Town of Caroline, New York.......10

6. Map showing well locations in the upper Sixmile Creek valley and West Branch Owego Creek valley, Town of Caroline, New York

7. Map showing aquifer types in upper Sixmile Creek and West Branch Owego Creek valley, Town of Caroline, New York

8. Diagram showing geohydrologic units section $A-A^{\prime}$ along the thalweg of the upper Sixmile Creek valley and West Branch Owego Creek valley, Town of Caroline, New York

9. Diagram showing well log of Climate Response Network well TM1968, near Slaterville Springs, New York

10. Map and diagram showing seismic-refraction survey $B-B^{\prime}$ along Flatiron Road, Town of Caroline, New York: A location of line of section, and B seismic profile

11. Map and diagram showing seismic-refraction surveys. Town of Caroline, New York: (A) location of surveys $C-C^{\prime}$ (north of Landon Road) and D-D' (along VanDemark Road) in upper Sixmile Creek valley, (B) seismic profile C-C' north of Landon Road, and (C) geohydrologic section D-D' along VanDemark Road....

12. Map showing water table in the unconfined aquifer and potentiometric surface in the upper confined aquifer in upper Sixmile Creek valley and West Branch Owego Creek valley, Town of Caroline, New York

13. Map showing the potentiometric surface in the basal confined aquifer in upper Sixmile Creek valley, Town of Caroline, New York

14. Diagram showing well log and construction details of USGS test wells TM 994 and TM1967 at Caroline Elementary School near Slaterville Springs, New York

15. Hydrograph showing the water level below land surface from January 1, 2005, to December 31, 2007, in U.S. Geological Survey Climate Response Network well TM1968 
16. Diagram showing sources of recharge to and discharge from valley-fill aquifers in New York.

17. Photograph showing the volumetric measurement of a tributary entering 200 feet upstream of Sixmile Creek at Brooktondale, NY, streamgage on July 16, 2007.

18. Graphs showing discharge for Sixmile Creek at Brooktondale, New York (USGS streamgage ID number 04233286) for (A) water year 2003, (B) water year 2004, (C) water year 2005, and (D) water year 2006

19. Graphs showing results of hydrograph separation analyses for Sixmile Creek at Brooktondale, New York (upper Sixmile Creek basin) and Sixmile Creek at Bethel Grove, New York (lower Sixmile Creek basin) streamgag for theperiod 2003-07.

20. Hydrograph of groundwater levels in monitoring well TM 999 near bridge over Buffalo Road, from August 7, 1993, to November 7, 1994, Slaterville Springs, New York

21. Map showing the location of groundwater and surface-water sampling sites in upper Sixmile Creek valley and West Branch Owego Creek valley, Town of Caroline, New York

22. Diagrams illustrating variability in major ion composition of surface water and groundwater in the lower Sixmile Creek and West Branch Owego Creek valleys, Town of Caroline, New York.

23. Photograph showing the Deer Licks historic highway marker along the side of Valley Road, Town of Caroline, New York

\section{Tables}

1. Range, mean, and median reported well yields and well depths in the Sixmile Creek and West Branch Owego Creek valley-fill aquifer, Town of Caroline, NewYork

2. Physical properties, and concentrations of inorganic constituents and nutrients in surface-water samples from Sixmile Creek at Brooktondale, New York, 2003-2005

3. Physical properties, and concentrations of inorganic constituents and nutrients in surface-water samples from selected tributaries in upper Sixmile Creek basin and in West Branch Owego Creek basin, New York, 2004-2005 ....

4. Physical properties, and concentrations of inorganic constituents and nutrients in groundwater samples from upper Sixmile Creek and West Branch Owego Creek valley, 2004-2005

5. Data on apparent groundwater ages from groundwater samples collected from three wells that tap the confined valley-fill aquifers in upper Sixmile Creek valley, Town of Caroline, New York 


\section{Conversion Factors and Datum}

\begin{tabular}{|c|c|c|}
\hline Multiply & By & To obtain \\
\hline \multicolumn{3}{|c|}{ Length } \\
\hline inch (in.) & 2.54 & centimeter $(\mathrm{cm})$ \\
\hline foot $(\mathrm{ft})$ & 0.3048 & meter $(\mathrm{m})$ \\
\hline mile (mi) & 1.609 & kilometer (km) \\
\hline \multicolumn{3}{|c|}{ Area } \\
\hline square foot $\left(\mathrm{ft}^{2}\right)$ & 929.0 & square centimeter $\left(\mathrm{cm}^{2}\right)$ \\
\hline square foot $\left(\mathrm{ft}^{2}\right)$ & 0.09290 & square meter $\left(\mathrm{m}^{2}\right)$ \\
\hline square mile $\left(\mathrm{mi}^{2}\right)$ & 2.590 & square kilometer $\left(\mathrm{km}^{2}\right)$ \\
\hline \multicolumn{3}{|c|}{ Volume } \\
\hline gallon (gal) & 3.785 & liter $(\mathrm{L})$ \\
\hline gallon (gal) & 0.003785 & cubic meter $\left(\mathrm{m}^{3}\right)$ \\
\hline million gallons (Mgal) & 3,785 & cubic meter $\left(\mathrm{m}^{3}\right)$ \\
\hline cubic foot $\left(\mathrm{ft}^{3}\right)$ & 0.02832 & cubic meter $\left(\mathrm{m}^{3}\right)$ \\
\hline \multicolumn{3}{|c|}{ Flow rate } \\
\hline foot per year (ft/yr) & 0.3048 & meter per year $(\mathrm{m} / \mathrm{yr})$ \\
\hline cubic foot per second $\left(\mathrm{ft}^{3} / \mathrm{s}\right)$ & 0.02832 & cubic meter per second $\left(\mathrm{m}^{3} / \mathrm{s}\right)$ \\
\hline $\begin{array}{l}\text { cubic foot per second per square mile } \\
{\left[\left(\mathrm{ft}^{3} / \mathrm{s}\right) / \mathrm{mi}^{2}\right]}\end{array}$ & 0.01093 & $\begin{array}{l}\text { cubic meter per second per square } \\
\text { kilometer }\left[\left(\mathrm{m}^{3} / \mathrm{s}\right) / \mathrm{km}^{2}\right]\end{array}$ \\
\hline cubic foot per year $\left(\mathrm{ft}^{3} / \mathrm{yr}\right)$ & 0.02832 & cubic meter per year $\left(\mathrm{m}^{3} / \mathrm{yr}\right)$ \\
\hline gallon per minute (gal/min) & 0.06309 & liter per second $(\mathrm{L} / \mathrm{s})$ \\
\hline gallons per day (gal/d) & 0.003785 & cubic meter per day $\left(\mathrm{m}^{3} / \mathrm{d}\right)$ \\
\hline million gallons per day $(\mathrm{Mgal} / \mathrm{d})$ & 0.04381 & cubic meter per second $\left(\mathrm{m}^{3} / \mathrm{s}\right)$ \\
\hline $\begin{array}{l}\text { million gallons per day per square mile } \\
{\left[(\mathrm{Mgal} / \mathrm{d}) / \mathrm{mi}^{2}\right]}\end{array}$ & 1,461 & $\begin{array}{l}\text { cubic meter per day per square kilo- } \\
\text { meter }\left[\left(\mathrm{m}^{3} / \mathrm{d}\right) / \mathrm{km}^{2}\right]\end{array}$ \\
\hline inch per year (in/yr) & 25.4 & millimeter per year $(\mathrm{mm} / \mathrm{yr})$ \\
\hline \multicolumn{3}{|c|}{ Radioactivity } \\
\hline picocurie per liter $(\mathrm{pCi} / \mathrm{L})$ & 0.037 & becquerel per liter $(\mathrm{Bq} / \mathrm{L})$ \\
\hline \multicolumn{3}{|c|}{ Specific capacity } \\
\hline gallon per minute per foot $[(\mathrm{gal} / \mathrm{min}) / \mathrm{ft})]$ & 0.2070 & liter per second per meter $[(\mathrm{L} / \mathrm{s}) / \mathrm{m}]$ \\
\hline
\end{tabular}

Temperature in degrees Celsius $\left({ }^{\circ} \mathrm{C}\right)$ may be converted to degrees Fahrenheit $\left({ }^{\circ} \mathrm{F}\right)$ as follows:

$$
{ }^{\circ} \mathrm{F}=\left(1.8 x^{\circ} \mathrm{C}\right)+32
$$

Temperature in degrees Fahrenheit $\left({ }^{\circ} \mathrm{F}\right)$ may be converted to degrees Celsius $\left({ }^{\circ} \mathrm{C}\right)$ as follows:

$$
{ }^{\circ} \mathrm{C}=\left({ }^{\circ} \mathrm{F}-32\right) / 1.8
$$

Vertical coordinate information is referenced to the North American Vertical Datum of 1988 (NAVD 88).

Vertical coordinate information is referenced to the National Geodetic Vertical Datum of 1923 (NGVD 23).

Horizontal coordinate information is referenced to the North American Datum of 1983 (NAD 83). 


\section{List of Acronyms}

$\begin{array}{ll}\text { CFC } & \text { Chlorofluorocarbons } \\ \text { CRN } & \text { Climate Response Network } \\ \text { CSI } & \text { Community Science Institute } \\ \text { HYSEP } & \text { Hydrograph-separation computer program } \\ \text { MCL } & \text { Maximum contaminant level } \\ \text { NWIS } & \text { National Water Information System } \\ \text { NWQL } & \text { National Water Quality Laboratory } \\ \text { NYSDOH } & \text { New York State Department of Health } \\ \text { SMCL } & \text { Secondary maximum contaminant level } \\ \text { TM } & \text { Tompkins } \\ \text { TU } & \text { Tritium unit } \\ \text { USEPA } & \text { U.S. Environmental Protection Agency } \\ \text { USGS } & \text { U.S. Geological Survey }\end{array}$


This page has been left blank intentionally. 


\title{
Geohydrology and Water Quality of the Valley-Fill Aquifer System in the Upper Sixmile Creek and West Branch Owego Creek Valleys in the Town of Caroline, Tompkins County, New York
}

\author{
By Todd S. Miller
}

\section{Abstract}

In 2002, the U.S. Geological Survey, in cooperation with the Town of Caroline and Tompkins County Planning Department, began a study of the valley-fill aquifer system in upper Sixmile Creek and headwaters of West Branch Owego Creek valleys in the Town of Caroline, NY. The purpose of the study is to provide geohydrologic data to county and town planners as they develop a strategy to manage and protect their water resources. The first aquifer reach investigated in this series is in the Town of Caroline and includes the upper Sixmile Creek valley and part of West Branch Owego Creek valley. The portions of the valley-fill aquifer system that are comprised of saturated coarse-grained sediments including medium to coarse sand and sandy gravel form the major aquifers. Confined sand and gravel units form the major aquifers in the western and central portions of the upper Sixmile Creek valley, and an unconfined sand and gravel unit forms the major aquifer in the eastern portion of the upper Sixmile Creek valley and in the headwaters of the West Branch Owego Creek valley.

The valley-fill deposits are thinnest near the edges of the valley where they pinch out along the till-mantled bedrock valley walls. The thickness of the valley fill in the deepest part of the valley, at the western end of the study area, is about 100 feet $(\mathrm{ft})$; the thickness is greater than $165 \mathrm{ft}$ on top of the Valley Heads Moraine in the central part of the valley.

An estimated 750 people live over and rely on groundwater from the valley-fill aquifers in upper Sixmile Creek and West Branch Owego Creek valleys. Most groundwater withdrawn from the valley-fill aquifers is pumped from wells with open-ended 6-inch diameter casings; the remaining withdrawals are from shallow dug wells or cisterns that collect groundwater that discharges to springs (especially in the Brooktondale area). The valley-fill aquifers are the sources of water for about 200 households, several apartment complexes, two mobile home parks, a school, and several farms and small businesses. Most groundwater that is withdrawn from pumped wells is returned to the groundwater system via septic systems.

Groundwater in the upper and basal confined aquifers in the upper Sixmile Creek valley is under artesian conditions everywhere except where the water discharges to springs along bluffs in the western end of the Sixmile Creek valley. Principal sources of recharge to the confined aquifers are (1) the sides of the valley where the confined aquifers may extend up along the flank of the bedrock valley wall and crop out at land surface or are overlain and in contact with surficial coarse-grained deltaic and fluvial sediments that provide a pathway through which direct precipitation and seepage losses from tributary streams can reach the buried aquifers, or (2) where the buried aquifers are isolated and receive recharge only from adjacent fine-grained sediment and bedrock.

The base-flow and runoff components of total streamflow at two streamgages, Sixmile Creek at Brooktondale and Sixmile Creek at Bethel Grove, were calculated using hydrograph-separation techniques from 2003 to 2007 discharge records. Base flow constituted 64 and 56 percent of the total annual flow at the Brooktondale and Bethel Grove streamgages, respectively.

Water-quality samples were collected from 2003 to 2005 , with 10 surface-water samples collected seasonally during base-flow conditions at the Sixmile Creek at Brooktondale streamgage, and 12 samples were collected during base-flow conditions at several selected tributaries from 2004 to 2005. The predominant cation detected in the surface-water samples was calcium, but moderate amounts of magnesium, silica, and sodium were also detected; the major anions were bicarbonate, chloride, and sulfate. Sodium and chloride concentrations were relatively low in all samples but increased downstream from the Sixmile Creek sampling site at Six Hundred Road near Slaterville Springs, NY, to Brooktondale, NY; some of the increases may be attributed to road salt, but most are probably natural discharge of brackish water originating from deep zones in the bedrock that discharge upward into the valleyfill aquifer. The concentration of nitrate was less than 1.0 milligram per liter $(\mathrm{mg} / \mathrm{L})$ in all stream samples taken during 
base-flow periods except in the tributary to Sixmile Creek at Slaterville Springs on July 19, 2005, when the concentration was $1.91 \mathrm{mg} / \mathrm{L}$. Flow in this tributary during the summer originates from groundwater discharging from Valley Heads Moraine, which has large areas used for agriculture.

Groundwater samples were collected from 10 wells -9 finished in sand and gravel aquifers and 1 finished in bedrock. Results of the groundwater sample analyses indicate the water is generally of good quality. Water in the sand and gravel aquifers is predominantly of the calcium-bicarbonate type. The cation detected in the highest concentrations was calcium; values ranged from 25.8 to $80.1 \mathrm{mg} / \mathrm{L}$. Sodium values ranged from 2.6 to $106 \mathrm{mg} / \mathrm{L}$; two samples exceeded the U.S. Environmental Protection Agency Drinking Water Advisory (30 to $60 \mathrm{mg} / \mathrm{L}$ ) for sodium. Variations in sodium concentrations were probably due to either local enrichment through road de-icing salts or brackish water from bedrock that locally discharges to the valley. Nitrate concentrations in five of nine samples collected from the valley-fill aquifer were below the detection limit of $0.060 \mathrm{mg} / \mathrm{L}$; concentrations ranged from 0.239 to $2.68 \mathrm{mg} / \mathrm{L}$ in the four wells that had concentrations above the detection limit.

Three groundwater samples were collected and analyzed for chlorofluorocarbons (CFCs) and ${ }^{3} \mathrm{H}$ to determine groundwater age. The results of the $\mathrm{CFC}$ and ${ }^{3} \mathrm{H}$ samples indicated that the apparent age of the water from the flowing well at the Caroline Town Hall was early to late 1950s; in the shallow test well (39 ft deep) at the Caroline Elementary School, early-to-late 1970s; and from the deep test well (TM1967) at the school, early-to-late 1950s.

The reported yields by water-well drillers were greater for the unconfined sand and gravel aquifer-a median of 15 gallons per minute - than for the confined aquifers - $\mathrm{a}$ median of 12 gallons per minute. Bedrock wells generally had smaller yields (median 6 gallons per minute) than the valleyfill aquifers. The mean well depths for the various aquifer types were: $42 \mathrm{ft}$ for the unconfined sand and gravel aquifer, $64 \mathrm{ft}$ for the confined sand and gravel aquifers, and $149 \mathrm{ft}$ for bedrock aquifers.

\section{Introduction}

In 2002, the U.S. Geological Survey (USGS), in cooperation with the Tompkins County Planning Department, began a series of studies of the valley-fill aquifer in Tompkins County in order to provide geohydrologic data to county and town planners as they develop a strategy to manage and protect their water resources. A reconnaissance-level USGS aquifer map report "Unconsolidated Aquifers in Tompkins County, New York" (Miller, 2000) was used as a guide to delineate 17 reaches of valley-fill aquifers (fig. 1) to investigate in more detail during approximately the next 20 years. The extents of the reaches were based mostly on natural hydrologic boundaries, but in some cases political boundaries were also considered. Reach lengths were limited to about 3 to $10 \mathrm{mi}$ each to be logistically manageable. In 2002, the USGS, in cooperation with the Town of Caroline and the Tompkins County Planning Department, began a study of the valley-fill aquifer in upper Sixmile Creek and the headwaters of West Branch Owego Creek valleys in the Town of Caroline (fig. 1). Where a reach of valley-fill deposits contains multiple aquifers, that reach is defined as an aquifer system, but not all reaches have more than one aquifer.

Tompkins County lies within the northern area of the Appalachian Plateau in central New York (fig. 2). The northern part of the county is within the extensively glacially eroded Finger Lakes region, with rounded hills of low to moderate relief; the southern part of the county lies within the Appalachian Plateau of moderately high relief (fig. 2). The valley-fill aquifer in the upper Sixmile Creek and West Branch Owego Creek valley described in this report is in the Appalachian Plateau region (figs. 1 and 2).

The study area for this report includes confined and unconfined aquifers in the upper Sixmile Creek basin and the adjacent West Branch Owego Creek basin to the east (fig. 3). In this report, "Sixmile Creek basin" refers to the entire watershed that drains to Sixmile Creek; "Sixmile Creek valley" and "West Branch Owego Creek valley" refer to the relatively flat, low-lying valley floors and underlying valleyfill deposits that are beneath the main channel of Sixmile Creek and adjacent headwaters of the West Branch Owego Creek valleys.

The geologic history of Sixmile Creek basin and the headwaters of West Branch Owego Creek basin (discussed in more detail in the Geology section of this report) has resulted in the creation of two distinct hydrophysiographic settings, which enabled the division of Sixmile Creek valley into two areas - upper Sixmile Creek valley, including the headwaters of West Branch Owego Creek valley, and lower Sixmile Creek valley, including the headwaters of Willseyville Creek (figs. 1 and 3). Upper Sixmile Creek valley and the headwaters of West Branch Owego Creek valley are higher in altitude and have undergone less erosion by ice than lower Sixmile Creek valley. The depositional environment of the upper deposits in upper Sixmile Creek valley was dominated by glaciofluvial meltwater and post-glacial fluvial processes, whereas in the lower Sixmile Creek valley, the upper portion of the valley fill was dominated by subglacial processes (deposition of till).

\section{Purpose and Scope}

The Town of Caroline and Tompkins County need geohydrologic data regarding the major valley-fill aquifers within the town to develop a strategy to manage and protect their water resources. Interest in the interaction between groundwater and surface water has increased in recent years due to widespread concerns related to water supply and water quality. This report describes the geohydrology of the valley-fill aquifer system in the upper Sixmile Creek 


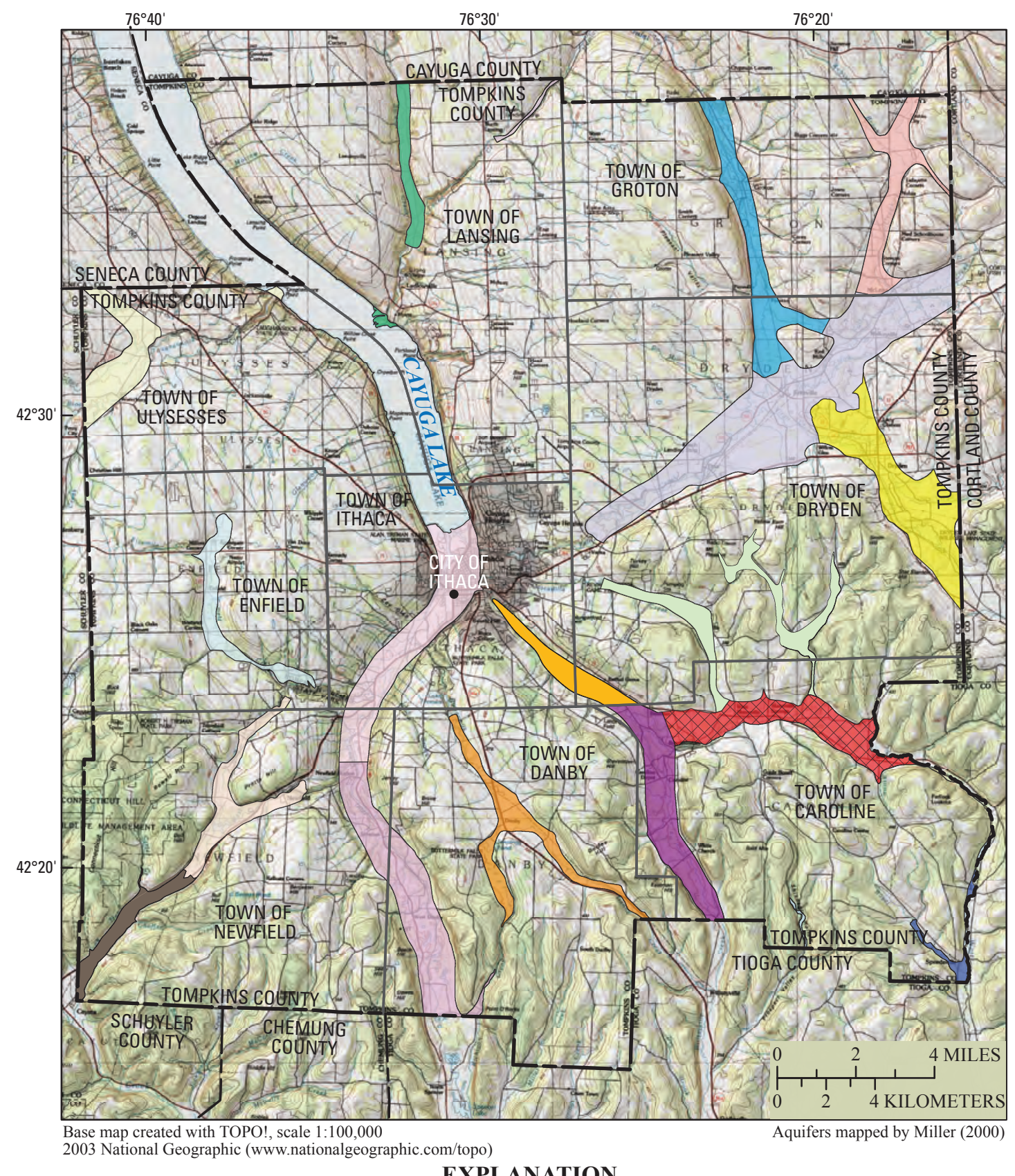

EXPLANATION

Aquifer reach names

\begin{tabular}{|l}
\hline$\quad$ Cascadilla Creek valley and upland Sixmile Creek valley \\
\hline$\quad$ Enfield Creek valley \\
\hline$\square$ Lower Cayuga Inlet valley \\
\hline$\square$ Lower Fall Creek valley \\
$\square \quad$ Lower Sixmile Creek valley (Towns of Dryden and Ithaca) \\
$\square \quad$ Owasco Inlet valley \\
Pony Hollow valley \\
$\square$ Salmon Creek/Myers Point/Locke Creek \\
$\square \quad$ Taughannock Creek valley and delta
\end{tabular}

\begin{tabular}{l}
\hline Upper Buttermilk Creek and Danby Creek valleys \\
\hline Upper Cayuga Inlet valley \\
\hline$\square$ Upper Fall Creek valley \\
$\begin{array}{l}\text { Upper Sixmile Creek and West Branch Owego Creek valleys } \\
\text { (subject of this study) }\end{array}$ \\
Virgil Creek valley \\
West Branch Cayuga Inlet and Fish Kill valleys \\
West Branch Owego Creek valley and tributaries \\
Lower Sixmile Creek and Willseyville Creek valleys \\
(Town of Caroline)
\end{tabular}

Figure 1. Location of 17 unconsolidated aquifer reaches in Tompkins County, New York. 


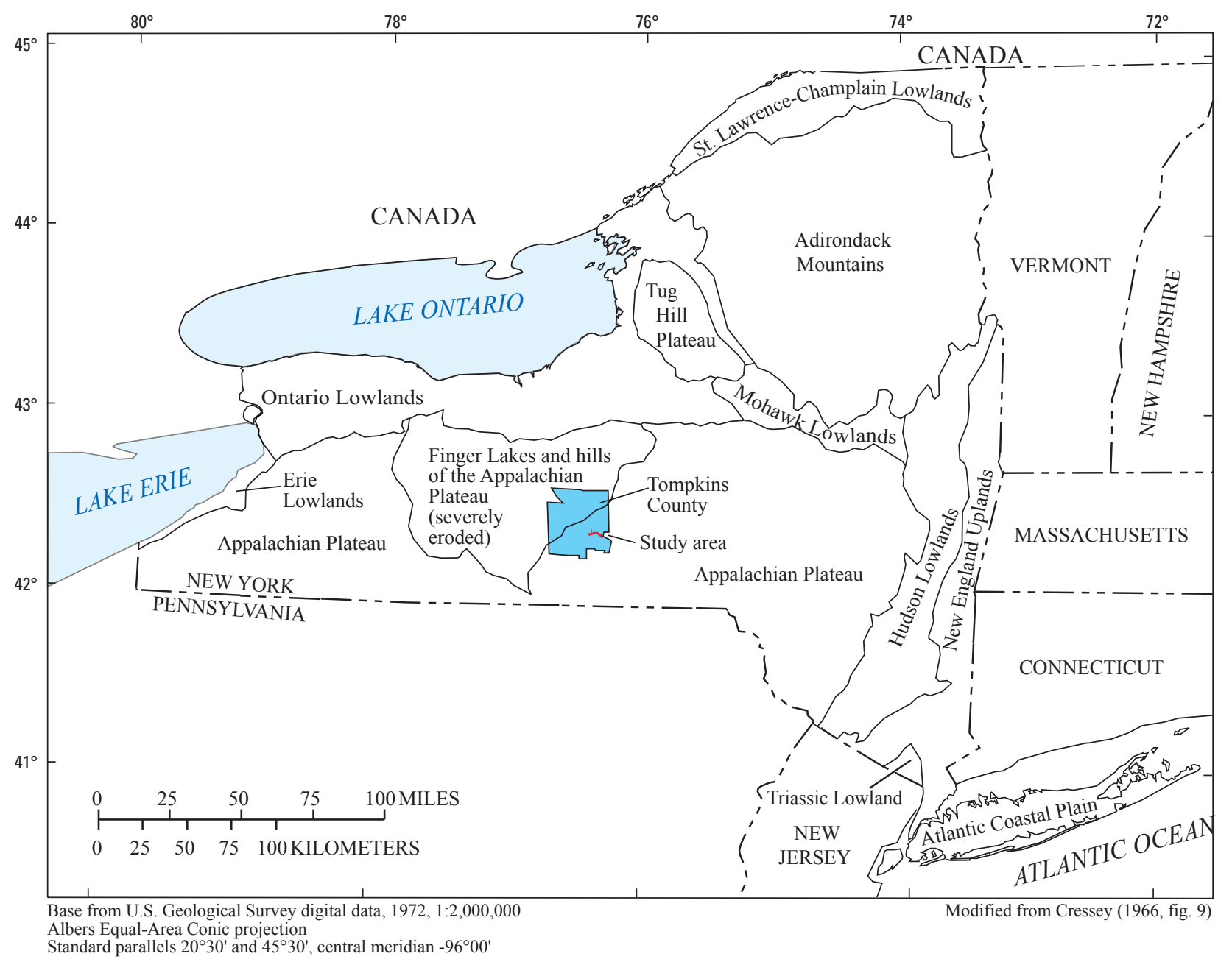

Figure 2. Physiographic features and location of upper Sixmile Creek valley and West Branch Owego Creek valley study area in Tompkins County, New York.

and the headwaters of West Branch Owego Creek valleys, including (1) the geologic geometry; (2) the groundwater flow system, including water levels, groundwater and surface-water interaction, recharge and discharge conditions; (3) water quality, including concentrations of common ions and nutrients; and (4) groundwater age. To aid in these descriptions, the following are being included in this report: (1) geohydrologic sections; (2) maps and diagrams depicting well locations, geology, groundwater levels, and the direction of groundwater flow; and (3) tables of well records and waterquality data.

\section{Description of Study Area}

The study area is on the northern rim of the Appalachian Plateau (fig. 2) where, over millions of years, formerly southward-draining streams have been pirated by advancing southward-incising streams, which have courses that presently drain northward into the Great Lakes. The study area extends eastward 4.1 miles from Brooktondale, NY, along the Sixmile Creek valley to the surface-water divide between Sixmile Creek and West Branch Owego Creek (about 1.6 mi east of Slaterville Springs, NY) and $2.5 \mathrm{mi}$ eastward into the West Branch Owego Creek valley from the surface-water divide (figs. 3 and 4). Overall, the valley-fill aquifer is $6.6 \mathrm{mi}$ in length, averages $0.6 \mathrm{mi}$ in width, and has a surface area of $4.7 \mathrm{mi}^{2}$. Range in altitude between hilltops and the valley floor varies from 300 to $1,000 \mathrm{ft}$, with hilltop altitudes generally less than 2,000 ft above NGVD29. Hilltops are slightly higher in the southern and eastern parts of the study area (ranging from 1,700 to $2,000 \mathrm{ft}$ in altitude) than in the western part of the study area (ranging from 1,500 to $1,700 \mathrm{ft}$ in altitude, fig. 4). 


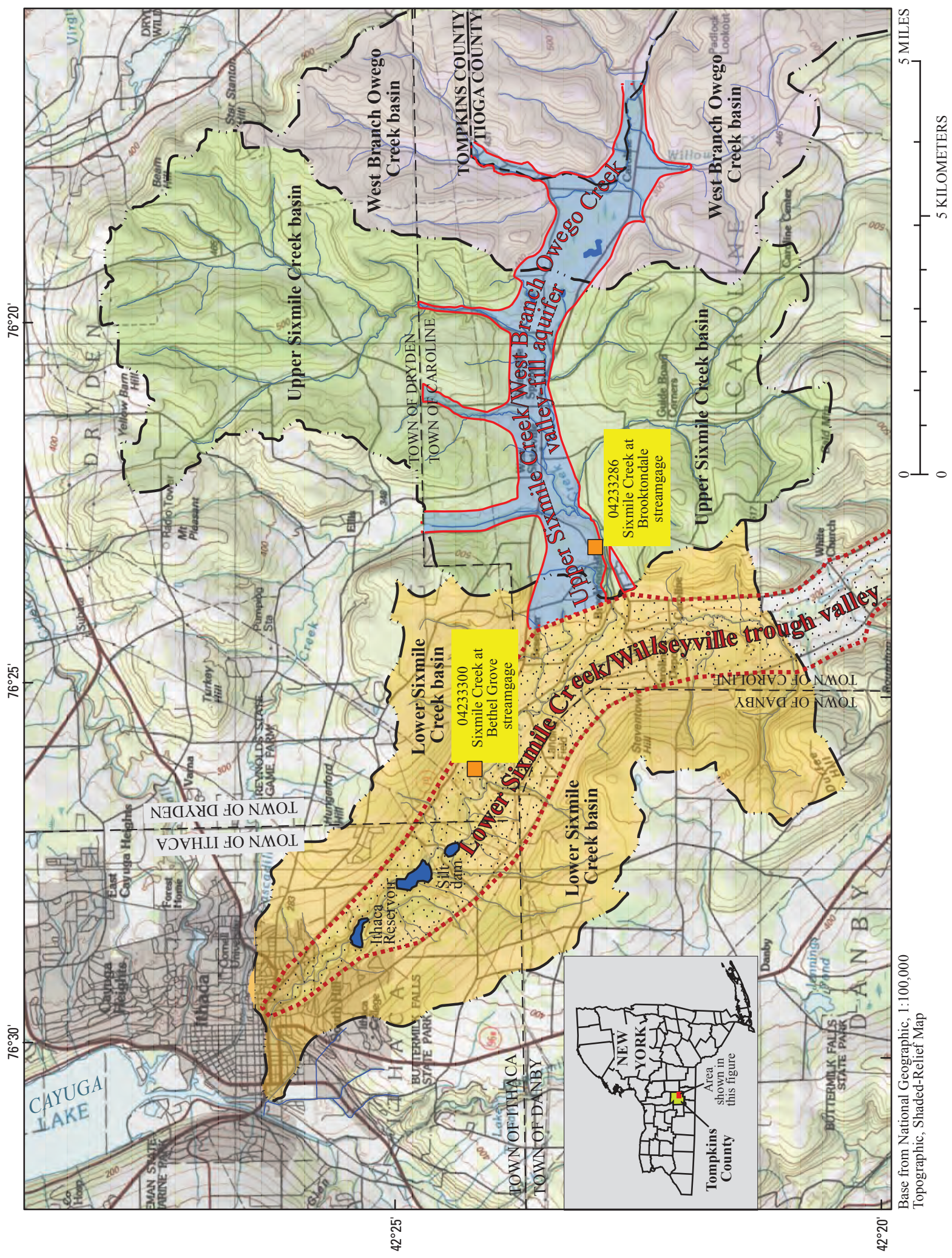

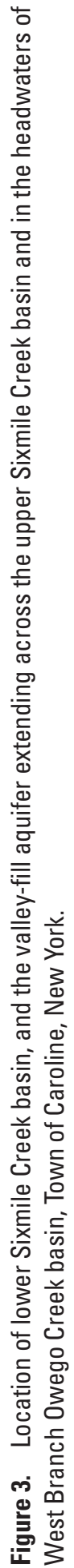




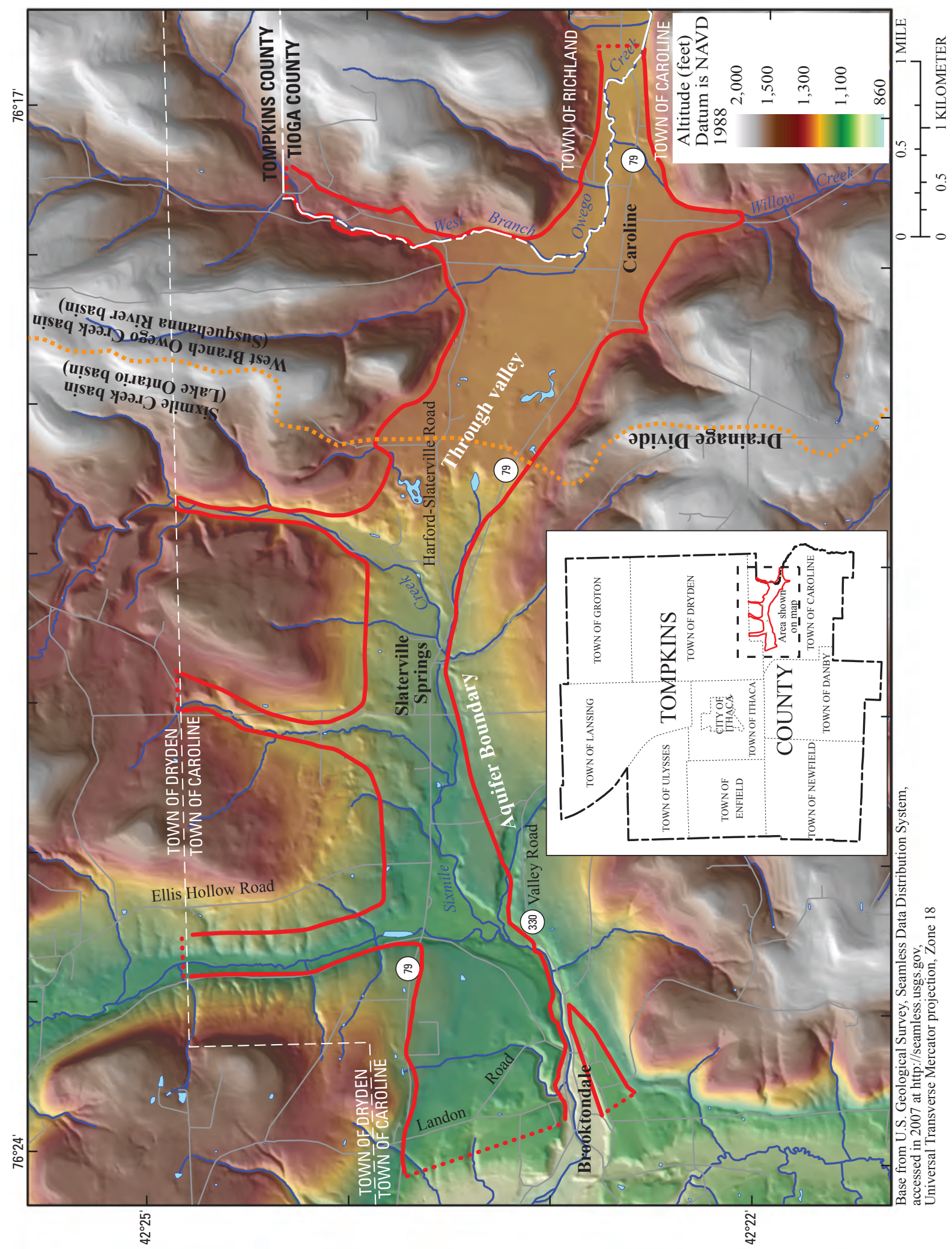

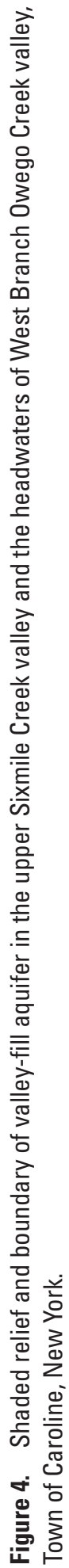




\section{Previous Studies}

In 1988, the USGS conducted an investigation of 17 headwater valleys in upstate New York (Randall and others, 1988); the headwaters of West Branch Owego Creek valley in the Town of Caroline (in the eastern part of this investigation) was one of the areas studied. The study included a well inventory and a brief evaluation of the geology and hydrology of the valley-fill aquifer.

Additional well records were collected by Miller (2000) for a general countywide aquifer study of Tompkins County. The results of this study were used to produce a map report, which delineates the extent of unconsolidated aquifers in Tompkins County.

Reconnaissance surficial geologic mapping at the scale of 1:24,000 of the headwaters of West Branch Owego Creek was done by Waller in 1982 (in Randall and others, 1988). Surficial geology also was mapped at the scale of 1:250,000 by Muller and Cadwell (1986) for a statewide mapping effort and was a reconnaissance study. Little geologic mapping has been conducted in upper Sixmile Creek valley and no subsurface stratigraphy has been investigated. Soils data were mapped at a scale of 1:20,000 (Neeley, 1961).

\section{Data Collection}

The USGS collected the following types of information for inclusion in this report: geologic data, seismic-refraction surveys, well stratigraphic records collected through well inventory and test drilling, water-level and streamflow measurements, and water-quality data of surface water and groundwater.

\section{Geologic Data}

Geologic data were collected by use of seismic-refraction surveys, field reconnaissance, interpretation of topographic maps and orthophotos, and review of available geologic reports, soil maps, and well-drilling records.

\section{Seismic-Refraction Surveys}

The seismic-refraction survey method uses refracted compressional waves of seismic energy and is based on the time for energy generated at a point, such as a small explosive charge, to travel through the ground to receivers (geophones). The velocity of sound traveling through unsaturated unconsolidated deposits, saturated unconsolidated deposits, and bedrock can be calculated, and this velocity is used to predict the depth to bedrock. Seismic-refraction techniques used in this study are described by Haeni (1988). Seismicrefraction surveys were conducted at three sites to supplement data from test drilling.
From 2003 to 2005, seismic-refraction data were collected at three sites by using a 12-channel signalenhancement seismograph. A series of 12 geophones spaced either 50 or $100 \mathrm{ft}$ apart were inserted into the ground, and arrival times of compressional waves generated by explosives buried 4 to $5 \mathrm{ft}$ below land surface were recorded and plotted as a function of "source-to-geophone" distances. In the seismic lines where the water table was relatively shallow (generally less than $5 \mathrm{ft}$ below land surface), the unsaturated zone was considered too thin to include as a layer and was ignored, and a two-layer (saturated unconsolidated sediments and top of bedrock) boundary-formula computer analysis (Scott and others, 1972) was used to calculate depths to bedrock. In the seismic line where the unsaturated zone was 10 to $20 \mathrm{ft}$ thick or more, a three-layer (saturated unconsolidated sediments and top of bedrock) boundary-formula computer analysis (Scott and others, 1972) was used to calculate depths to water table and to bedrock.

\section{Well Inventory, Test Drilling, Groundwater-Level and Streamflow Measurements}

Seventy-eight well records were collected and compiled in this report (Appendix 1). Forty-eight well records were obtained from water-well drillers' reports that were submitted during the years 2000-07 to the New York State Department of Environmental Conservation Water Well Completion Report program. Data from the well drillers' reports include: lithologic logs, water levels, estimated well yields, and well construction information (well and casing depths, casing diameter, and length of casing sticking up above land surface). The well inventory was augmented by test drilling at two sites using air-rotary drilling methods in which 6-in. diameter, steel-cased observation wells were installed to obtain data on stratigraphy and water levels in the aquifers. The casings were perforated where substantial water-bearing zones were penetrated in the valley-fill deposits. All records collected for this study were entered into the USGS Groundwater Site Inventory computer data base and are accessible at http://waterdata.usgs.gov/ny/nwis/inventory.

Levels were run to about half of the wells from the drillers' logs to determine the altitudes of the water-levelmeasuring points, which typically coincide with the top of the well casing. The altitudes of land surface and measuring points of the remaining wells were estimated from USGS 1:24000 scale topographic contour maps. When possible, depth to water in wells was measured using an electric tape. Where measured, depths were converted to altitudes, plotted on a map, and contoured to depict the water table in unconfined aquifers and potentiometric surfaces in the confined aquifers. Levels were also run to the streamgage at Brooktondale (04233286); all altitudes were determined using standard surveying methods (Kennedy, 1990) and are generally accurate to within $0.01 \mathrm{ft}$. Streamflow was measured using a current meter in several reaches of Sixmile Creek and tributary 
streams during collection of stream water-quality samples during the years 2003-05. Streamflow measuring techniques are described by Buchanan and Somers (1982).

\section{Water-Quality Sampling and Analysis}

For this investigation, groundwater samples were collected from 10 wells from 2004 to 2005. Ten surface-water samples were collected seasonally during base-flow conditions at Sixmile Creek at Brooktondale streamgage (04233286) from 2003 to 2005, and 13 samples were collected during base-flow conditions at several selected tributaries to Sixmile Creek and West Branch Owego Creek from 2004 to 2005. The samples for inorganic constituents and nutrients were analyzed by the USGS National Water Quality Laboratory (NWQL) in Denver, Co. and field measurements of $\mathrm{pH}$, specific conductance, and water temperature were taken. The samples were collected using the equal-width-increment method and processed following methods described in the USGS National Field Manual for the Collection of Water-Quality Data (U.S. Geological Survey, variously dated).

Nine groundwater samples were collected from wells completed in sand and gravel aquifers, and one was collected from a well finished in bedrock. In the seven sampled domestic wells that had pumps, samples were collected by first turning the well pump on and allowing it to run for about 20 minutes or until at least five casing-volumes of well water had been purged from the casing. A raw-water spigot between the well and the pressure tank was then opened, and the water was allowed to run for several more minutes to flush the line to the spigot. Samples were then collected from the raw-water spigot to bypass all water-treatment systems and ensure that the samples collected were representative of the water in the aquifer. In the three test wells completed for this study, a stainless-steel submersible pump was used to purge 5 to 10 casing-volumes of water from the well before collecting water samples.

Three groundwater samples also were collected and analyzed for chlorofluorocarbons (CFCs) and the ${ }^{3} \mathrm{H}$ isotope to determine the recharge age of the water-the date when it first entered the saturated groundwater system. $3 \mathrm{H}$ samples were analyzed at the USGS Isotope Geochemistry Laboratory in Menlo Park, Calif. The method of preparing the ${ }^{3} \mathrm{H}$ sample is described by Ostlund and Werner (1962) and the analysis method is described by Thatcher and others (1977). CFC samples were collected according to sampling methods that minimize atmospheric exposure (U.S. Geological Survey, variously dated) and were analyzed at the USGS Chlorofluorocarbon Laboratory in Reston, Va. Concentrations of CFC-12, CFC-11, and CFC-113 were measured by purgeand-trap gas chromatography and an electron-capture detector (Busenberg and Plummer, 1992). Age-dating of groundwater using this method gives an approximate time since the water recharged the aquifer (from precipitation) and entered the saturated zone, essentially fixing the $\mathrm{CFC}$ concentrations by cutting off their interaction with the atmosphere. Ages are determined by matching the concentrations of the tracers in groundwater to historical atmospheric concentrations of these tracers. Details of CFC and ${ }^{3} \mathrm{H}$ dating are explained in Plummer and others (1993) and Reilly and others (1994).

In the three wells where CFC samples were collected, samples were also collected and analyzed for concentrations of dissolved gases (argon, methane, carbon dioxide, nitrogen, and oxygen) and excess air. The results of these gas analyses were used to estimate recharge temperatures and to reconstruct initial nitrate concentrations based on the amount of denitrification that has occurred. Recharge temperature and excess air of recharge water are important components in interpreting the age of the water, along with concentrations of CFCs (Heaton, 1981; Heaton and Vogel, 1981; Stute and Schlosser, 1999).

\section{Geology}

The Northeastern United States was repeatedly covered by continental ice sheets during the past 2.5 million years (Teller, 1987). The chronology of glaciation and deglaciation in eastern North America is long and complex with many episodes of global cooling over the past 2.5 million years. The ice deepened some valleys, transported vast quantities of sediment, and deposited the sediment upon the scoured bedrock as a mantle of glacial drift. Each ice sheet eroded previously deposited unconsolidated sediments and bedrock and eventually redeposited the debris as a widespread but highly variable mantle of glacial drift. The most recent glaciation, referred to as the Wisconsinan episode, reached its maximum extent in most of northeastern North America about 21,000 years ago (Mickelson and others, 1983; Stone, 1995). The most recent deglaciation in New York was interrupted by several readvances and retreats. Some of these readvances and retreats were of a regional extent that reflected changes in climate, and others had more of a local extent that could be attributed to ice dynamics and the interaction of ice sheets with proglacial lakes (Randall, 2001).

Upper Sixmile Creek and West Branch Owego Creek valleys are in the northern perimeter of the Appalachian Plateau (fig. 2); the eastern part of the valley is near a former bedrock saddle that once crossed the valley and formed a preglacial drainage divide. The former saddle was enlarged and deepened by glacial erosion that conveyed large volumes of meltwater and sediment. It is likely that the former saddle was either removed or shifted in position as a result of glacial erosion - in the Finger Lakes region this feature is termed a "through valley" (fig. 4). Tarr (1905) described it as follows: "Along a number of valleys it is possible to pass from one drainage system to the other through open valleys in which the present divides are determined not by rock, but by drift deposits." 
Geologic materials in upper Sixmile Creek basin include bedrock, till, and stratified drift (fig. 5). Bedrock underlies the entire region but is mantled nearly everywhere by unconsolidated glacial drift that includes till or stratified drift deposits (fig. 5). Bedrock consists of Devonian shale and siltstone. Till is an unsorted, unstratified mixture of clay, silt, sand, gravel, and rocks deposited directly by glacial ice, rather than by meltwater. The larger gravel and rock, which are typically embedded in a fine-grained matrix consisting of clay, silt, and very fine sand, range in size from pebbles to boulders and typically are present directly overlying bedrock but also may be interbedded within the valley-fill drift in upper Sixmile Creek valley. Till has low permeability (low hydraulic conductivity) because it is poorly sorted material within a fine-grained matrix that was greatly compacted by the weight of the ice. Stratified drift, the end product of sediment deposition by glacial meltwater, is typically present in the major valleys and consists of layered, sorted glaciofluvial and glaciolacustrine sediments that were deposited in lowlands as the ice sheets retreated. When meltwaters flowed into these lakes, deltaic sands and gravel were deposited in near-shore environments, while further from shore, in the deeper parts of lakes, fine-grained (silt and clay) lake-bottom deposits accumulated. When the lake filled up with sediment or the lake drained, meltwaters deposited deltaic topset and fluvial sand and gravel on top of the deltaic deposits. The stratified drift comprised of sand and gravel forms the productive valleyfill aquifers in the study area. These aquifers are capable of supplying well yields more than an order of magnitude larger than are generally obtainable from the underlying shale bedrock.

\section{Bedrock Scouring}

Preglacial valleys that were oriented along the primary direction of ice movement, such as those valleys presently occupied by Cayuga Lake and lower Sixmile Creek valley (fig. 1), were extensively widened and deepened by flowing ice and subglacial meltwater. Erosion by ice had truncated bedrock hillsides (spurs), which resulted in creation of nearly straight, U-shaped bedrock troughs. Bedrock troughs in central New York are common along the northern rim of the Appalachian Plateau; many of these troughs are now contained in the Finger Lakes region. Clayton (1965) referred to the Finger Lake valleys as "intrusive troughs" that were carved when ice that flowed south from the Lake Ontario Plain encountered a landmass of higher altitude, in this case the Appalachian Plateau, and flowed uphill, against the regional slope. Bedrock troughs are often referred to as having U-shaped profiles although many are asymmetrical, with one valley wall steeper than the other. However, the more southward valleys and troughs intrude into the Appalachian Plateau (fig. 2), the width of valleys decreases, and the valley profiles transition from broad U-shaped to narrow U-shaped to V-shaped profiles.
East-west trending valleys that are tributaries to deep troughs, such as upper Sixmile Creek valley (figs. 1 and 3), were not oriented parallel to the direction of ice movement and underwent less intensive scouring, which resulted in less erosion than in north-south trending valleys. These east-west trending tributary valleys end high above the floor of the troughs they join and are known as "hanging valleys." The differing orientations of lower Sixmile Creek valley (roughly north-to-south) (fig. 1) and that of upper Sixmile Creek and West Branch Owego Creek valleys (east-to-west) facilitated the division of the basin into two parts, each with distinct geologic features and hydrologic conditions.

\section{Wisconsinan Drift}

The glacial history of the late Wisconsinan ice sheet in central New York was an unsteady process, marked by pauses and temporary readvances that complicate the stratigraphic record in the study area. Most of the unconsolidated sediments in this study area were probably deposited during the late periods of deglaciation of the late Wisconsinan. There was more meltwater available during this period due to a warmer climate than during preceding colder periods when the ice was advancing and primarily erosion was taking place.

All large northward-draining valleys along the northern rim of the Appalachian Plateau contain unconsolidated deposits up to several hundred feet thick. In general, the bulk of the valley fill consists of layers of tills and fine-grained lake deposits. Northward-draining valleys, such as the lower Sixmile Creek valley, favor deposition of mostly fine-grained sediment because proglacial lakes formed between the ice front to the north and the major surface-water divide to the south. The ice tended to melt and retreat relatively quickly because it was in contact with the lake, so there was relatively little time for meltwaters to deposit coarse-grained material. Although coarse-grained sediment (sand and gravel) is usually a minor component of the valley fill in north-draining valleys, locally, several tens of feet of sand and gravel accumulated in the study area and east of the Valley Heads Moraine, and at the delta near Brooktondale (fig. 5).

In central New York, the Valley Heads Moraine was deposited where the ice-margin paused as it retreated northward within the major valleys of the Finger Lakes region, including upper and lower Sixmile Creek valleys. The Valley Heads Moraine is defined by massive, hummocky deposits of coarse-grained, heterogeneous stratified drift that fill the valley from side to side. These deposits range in length from about $1,000 \mathrm{ft}$ to about $2 \mathrm{mi}$ and have been termed "valley-choker moraines" (MacClintock and Apfel, 1944) and "valley plugs" (Cadwell, 1972). In Sixmile Creek basin, the ice that formed the Valley Heads Moraine flowed south in the lower Sixmile Creek trough and, at near present day Brooktondale, a tongue of ice branched off and flowed eastward several miles. The extent of ice in the uplands of the upper Sixmile Creek basin is uncertain, however. When the ice front retreated in upper 


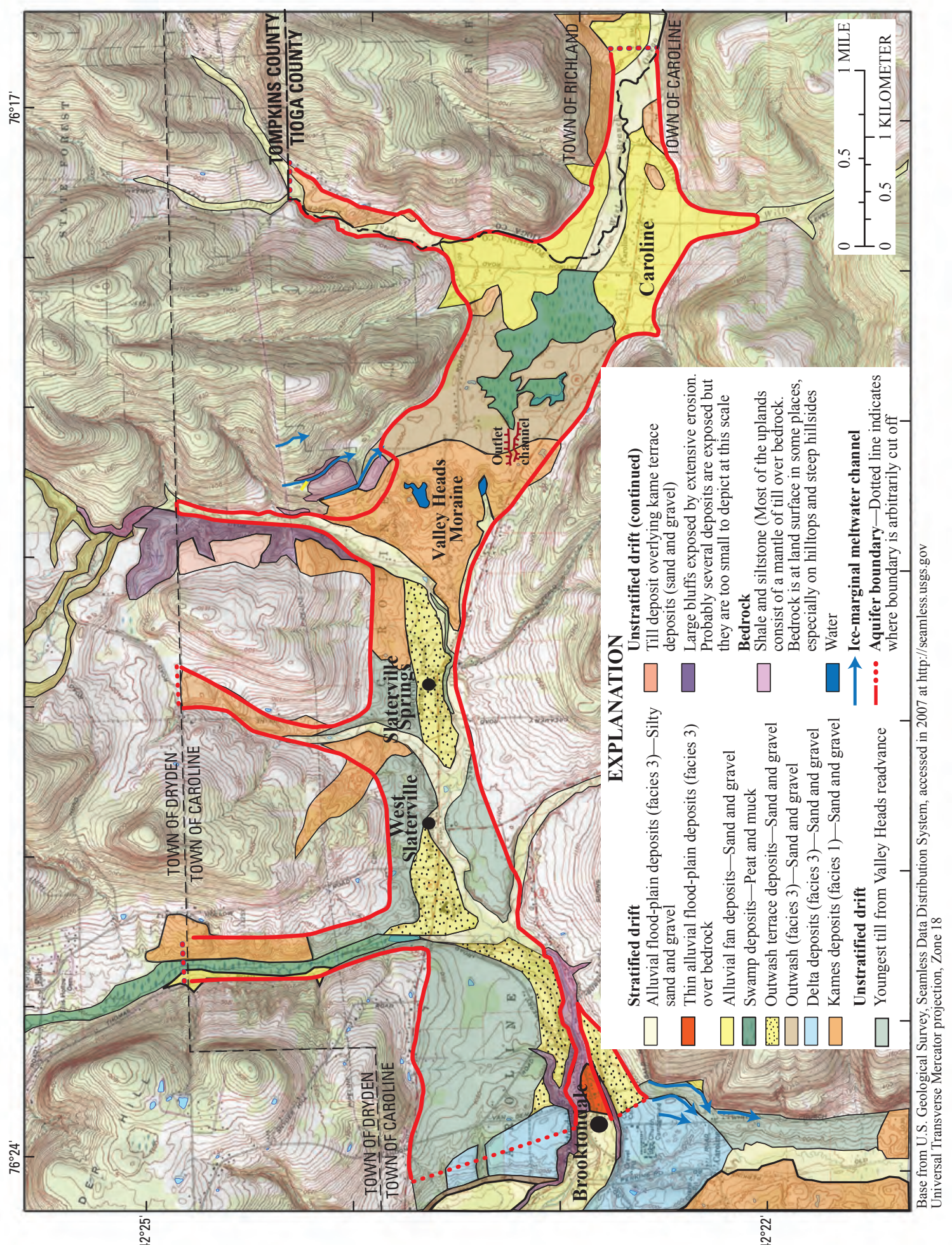

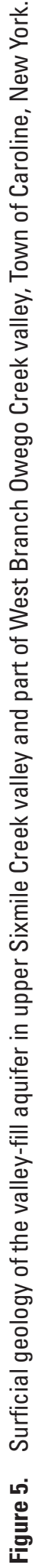


Sixmile Creek valley, it melted back westward until it joined the ice in lower Sixmile Creek valley, which retreated to the north.

Valley-fill deposits are thickest in the middle of the valley and thinnest along the edges where bedrock and till crops out at land surface. The deposits in the thalweg (the deepest part of the valley) also thicken to the east. The thickness of the valley-fill deposits is about $100 \mathrm{ft}$ at the west end of the study area. Data collected at a deep well (TM1979, fig. 6) drilled near the lip of the hanging valley at the west end of the study area indicate that the thickness of the valley fill is $104 \mathrm{ft}$. In the central part of the study area, two deep wells, TM1967 and TM2028 (fig. 6), penetrated bedrock at depths of 160 and $165 \mathrm{ft}$, respectively. The maximum thickness of the valley-fill drift is greater than $165 \mathrm{ft}$ at the Valley Heads Moraine, where a deep test well (TM1968, fig. 6) was drilled to a depth of $165 \mathrm{ft}$ without encountering bedrock. No wells in the eastern part of the study area penetrated to bedrock in the central part of the valley, although the maximum well depth was $90 \mathrm{ft}$ at well TM 56 (fig. 6).

\section{Depositional Facies}

According to Randall (2001), in nearly all valleys in the glaciated Northeastern United States, the stratified drift consists of three facies that reflect the depositional environment in which the sediments were laid down.

- Facies 1. Early deglacial, proximal, or ice-contact facies: predominantly coarse-grained, heterogeneous sediment, varying widely in degree of sorting; deposited close to active ice and (or) amid abundant stagnant ice masses.

- Facies 2. Mid-deglacial, distal facies: predominantly finegrained sediment, deposited in moderately large bodies of water, farther from active ice than facies 1 .

- Facies 3. Late-deglacial or postglacial, surficial facies: coarse-grained sediment; commonly well-sorted; deposited in shallow water and commonly atop facies 2 or 1 .

Where all three facies are present at one location, they form a characteristic, coarse over fine over coarse stratigraphy. At some locations, however, only one or two facies are present. Locally, the three-facies model can be an oversimplification of the true complexity of stratified-drift stratigraphy. Ice surges or readvances also result in local complexities. Despite local complexities and absences of individual facies, the three-depositional-facies stratigraphic concept is widely applicable throughout the glaciated Northeast (Fleisher, 1986; Miller and Randall, 1991; Randall, 1981).

\section{Facies 1-Ice-Contact Deposits}

Facies 1 contains large amounts of coarse-grained sediment (kame and outwash sand and gravel) transported tens of miles by subglacial streams in crevasses and tunnels beneath the ice or by ice-marginal streams that flowed beside stagnant ice at the ice margin. Many subglacial channels persisted throughout the later stages of glaciation and deposited sand or gravel atop bedrock near the retreating ice margin. These deposits became the basal sand and gravel aquifer in the study area. Much of the basal sand and gravel deposits was subsequently buried by fine-grained lacustrine and (or) till sediments (deposited as facies 2), which hydraulically confined the basal sand and gravel deposits and formed the confined aquifer in upper Sixmile Creek valley.

Sediment that was transported by meltwater issuing directly from the ice, as well as by streams from bordering uplands that were uncovered by ice, each contributed substantially to the deposition of stratified drift, but the ratio of sediment derived from these two sources differs from place to place (Randall, 2001). The lithology of most pebbles in the valley-fill gravel are similar to the local bedrock (gray Devonian-age shale in the Sixmile Creek basin), although the source of gravel is likely from upland streams that transported the clasts when the hills had been uncovered by ice. Conversely, when the pebbles contain abundant erratics (rocks not present in the local area, such as limestones, red sandstones, and igneous and metamorphic rocks), it is likely that this gravel was transported from further north directly by ice or by subglacial meltwater.

When the ice front was in contact with a proglacial lake, much of the fine-grained sediment remained in suspension and was later deposited downvalley as facies 2 . As the ice front retreated, the deposition of coarse facies 1 retreated with it. In some places, stagnant blocks of ice were left behind as the ice front retreated. Sediment partially or completely buried many of these ice blocks and as these ice blocks melted, kettle depressions resulted. Where the bottoms of kettle depressions are below the water table, kettle lakes, ponds, and bogs commonly form in them.

\section{Facies 2-Proglacial Lake Deposits}

Topographically low lakes were common during the advance and retreat of ice in valleys that were aligned in the direction of glacier flow (roughly north to south) such as the Finger Lake troughs and lower Sixmile Creek valley. Some of these valleys, which were intensively scoured by ice, were eroded below sea level (Mullins and Hinchey, 1989). Highlevel lakes sometimes developed in major headwater valleys, such as upper Sixmile Creek valley. As is present at most places where the Valley Heads Moraine had plugged valleys, there is an abandoned channel at the lowest point on the Valley Heads Moraine (Miller and others, 1998) where, initially, for a short duration (probably for several decades), a proglacial lake on the backside of the moraine drained via the outlet channel on the crest of the moraine.

Stratified fine-grained sediments consisting of fine sand, silt, and clay settled on the bottoms of proglacial lakes in distal areas from the ice front. In areas where subglacial meltwaters disgorged at the mouths of tunnels beneath the ice, subaquatic 


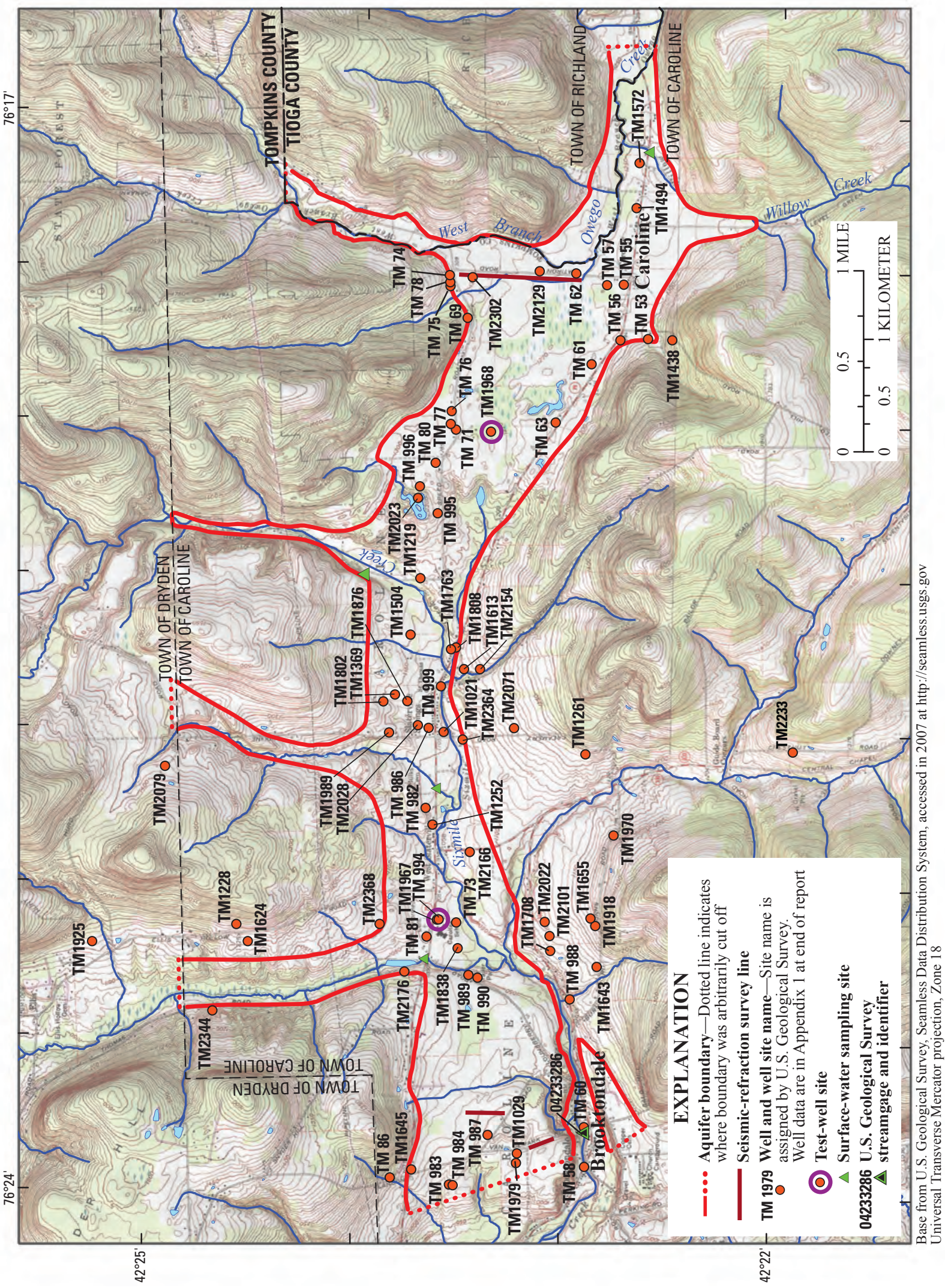

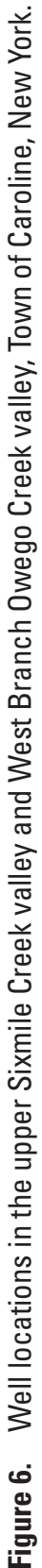


fans accumulated. These deposits consisted of sand and gravel in proximal areas to the ice, grading into finer sediments such as sand and silt further from the mouth of the tunnel. Deltas formed where meltwater flowing on top of and adjacent to the ice entered these proglacial lakes. The subaquatic fans and deltas typically consist of pebbly sands where the meltwater streams enter the lake, but grade into finer sediment such as fine sand and silt, in more distal parts of the lake. In upper Sixmile Creek valley, subaquatic fans may form parts of the basal aquifer on top of bedrock.

\section{Facies 3-Late- and Post-Glacial Deposits}

Facies 3 consists of surficial sand and gravel deposited in shallow ponded water or along stream channels late in the deglaciation of the area, or even after the glaciers had completely disappeared. Facies 3 typically is found atop the finer-grained, facies 2 deposits but can overlie facies 1 deposits as well; these deposits are commonly finer grained and better sorted than facies 1 deposits (Randall, 2001).

Examples of depositional environments where facies 3 deposits were laid down in the study area include (1) meltwaters that deposited extensive outwash (valley trains or outwash plains) in front (east) of the Valley Heads Moraine and into West Branch Owego Creek valley, (2) late-stage fluvial meltwater that eroded sediment in the upper part of the basin and deposited much of the sediment to form the topset beds of the delta west of Brooktondale, (3) modern post-glacial streams that aggraded alluvial sediments in lowlying areas on the valley floor, and (4) upland tributaries that deposited alluvial fans where the tributaries join the main valley (fig. 5).

The ratio of clay and silt to sand and gravel within the glacial drift varies as a function of bedrock lithology and the depositional environment (Randall, 2001). Sixmile Creek basin is underlain by relatively weak shale and siltstone, which readily separates into tiny fragments of constituent particles of clay, silt, and fine sand during erosion and transport by ice and meltwater. Many sand grains are tiny fragments of shale or siltstone. Conversely, erosion of coarsely crystalline metamorphic and igneous bedrock (for example, rocks that comprise the Adirondack Mountains and the Canadian shield north of Lake Ontario) tends to yield many hard, durable cobbles, pebbles, and medium-to-coarse sand-size mineral grains.

\section{Valley Heads Readvance}

The upper Sixmile Creek valley and the lower Sixmile Creek trough valley were overridden by a readvance of the ice at the time of formation of the Valley Heads Moraine system about 15,500 years ago (Fullerton, 1980). Randall (2001) identified the proximity where the Valley Heads ice readvanced into the northern rim of the Appalachian Plateauone of the regions where multiple drift layers are widespread and hydrologically important. The upper Sixmile Creek valley lies within this area. In this study area, evidence for these local readvances are found in cutbanks in Sixmile Creek and includes the presence of disturbed sediments (mostly thrust faults and folds in the till) caused by ice overriding previously deposited glacial sediments. The ice was thin at and near the terminus of these readvances; therefore, the erosion of underlying deposits was less pronounced because the ice was unable to scour down to bedrock. Instead, the relatively thin ice overrode previously deposited sediments and then, as the ice retreated again, it deposited additional till, glaciofluvial, and glaciolacustrine deposits over those older deposits. Fleisher (1991) hypothesized that ice tongues could easily readvance as much as $12 \mathrm{mi}$ across soft deformable sediments, such as fine-grained lake deposits. Because the ice did not completely remove older underlying sediments in the upper Sixmile Creek valley during the Valley Heads readvance, there is a complicated stack of two deglacial sequences in the valley.

\section{Hydrology of the Valley-Fill Aquifer System}

The upper Sixmile Creek and West Branch Owego Creek valley-fill aquifer system contain both confined and unconfined aquifers (figs. 7 and 8). Confining layers are made up of geologic material with low permeability (low hydraulic conductivity) that prevent groundwater from moving through rapidly. In this study area, the confining layers consist of clay and silt or till. An unconfined aquifer is composed of sediments of sufficient permeability that are able to store and yield usable amounts of water to wells. In an unconfined aquifer, the water table is at or near atmospheric pressure and is the upper boundary of the aquifer; this type of aquifer is bounded by a relatively impermeable unit at the base of the aquifer. A confined aquifer (also known as artesian aquifer) is composed of sediments of sufficient permeability that are able to store and yield usable amounts of water to wells, in which the aquifer is bounded between confining layers. In a confined aquifer, the potentiometric surface is always above the top of the geologic unit in which the water is stored and transmitted. When a confined aquifer is tapped by a well, water in the casing is forced up to its potentiometric altitude. If the hydraulic pressure in the confined aquifer is great enough, it may cause the water in the well to flow above land surface, in which case the well is referred to as a flowing-artesian well.

The upper Sixmile Creek valley is a moderately deep valley with a bedrock floor that is at an altitude of about 880 to $900 \mathrm{ft}$ near Brooktondale and rises slightly eastward toward the drainage divide between Sixmile Creek and West Branch Owego Creek. The western and central parts of the valley fill are generally less than $200 \mathrm{ft}$ thick and consist of predominantly fine-grained stratified drift (lacustrine very fine sand, silt, and clay) and till that are interlayered with two units of coarse-grained sand and gravel, which comprise the confined aquifers in that part of the study area (figs. 7 and 8). 


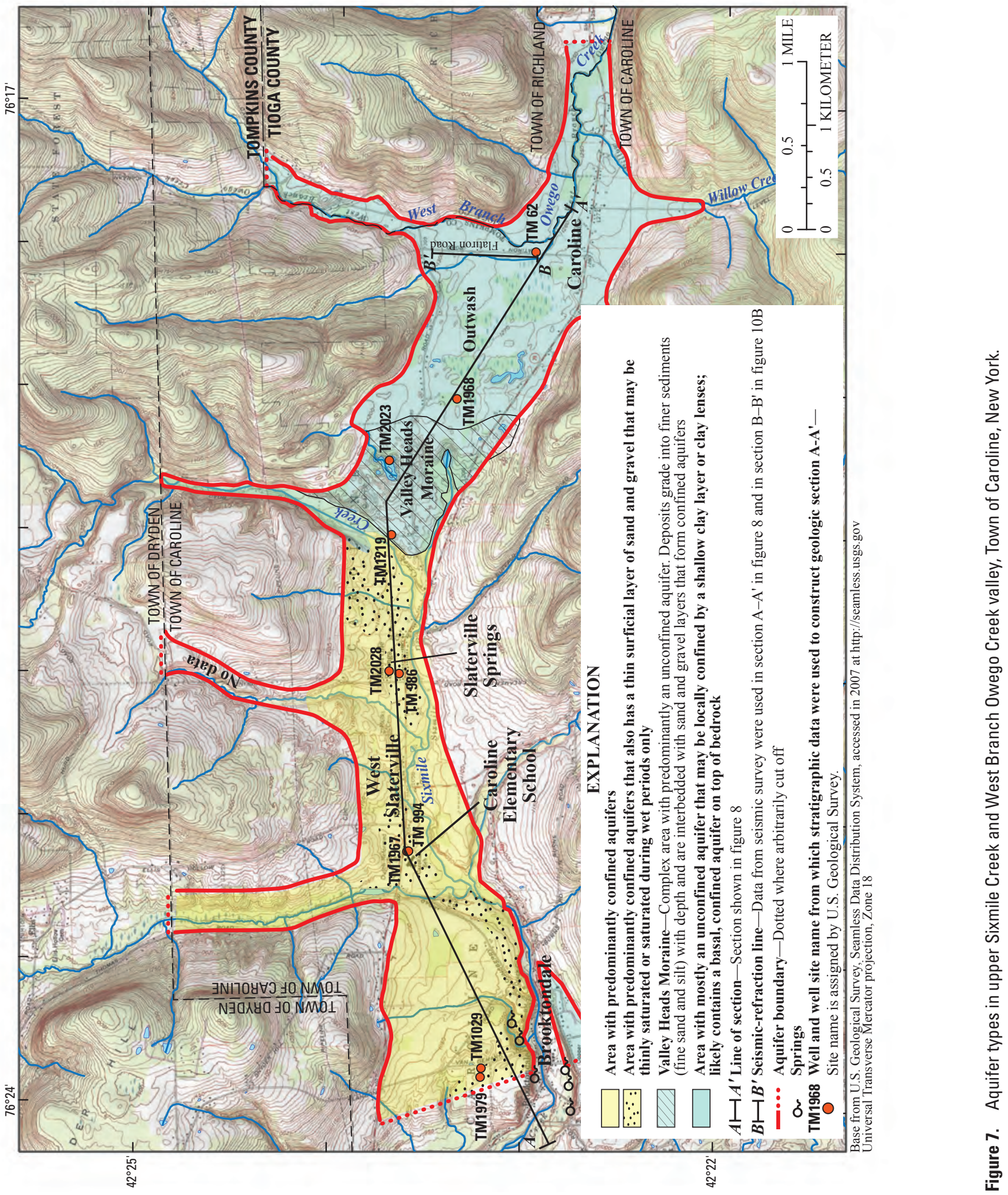




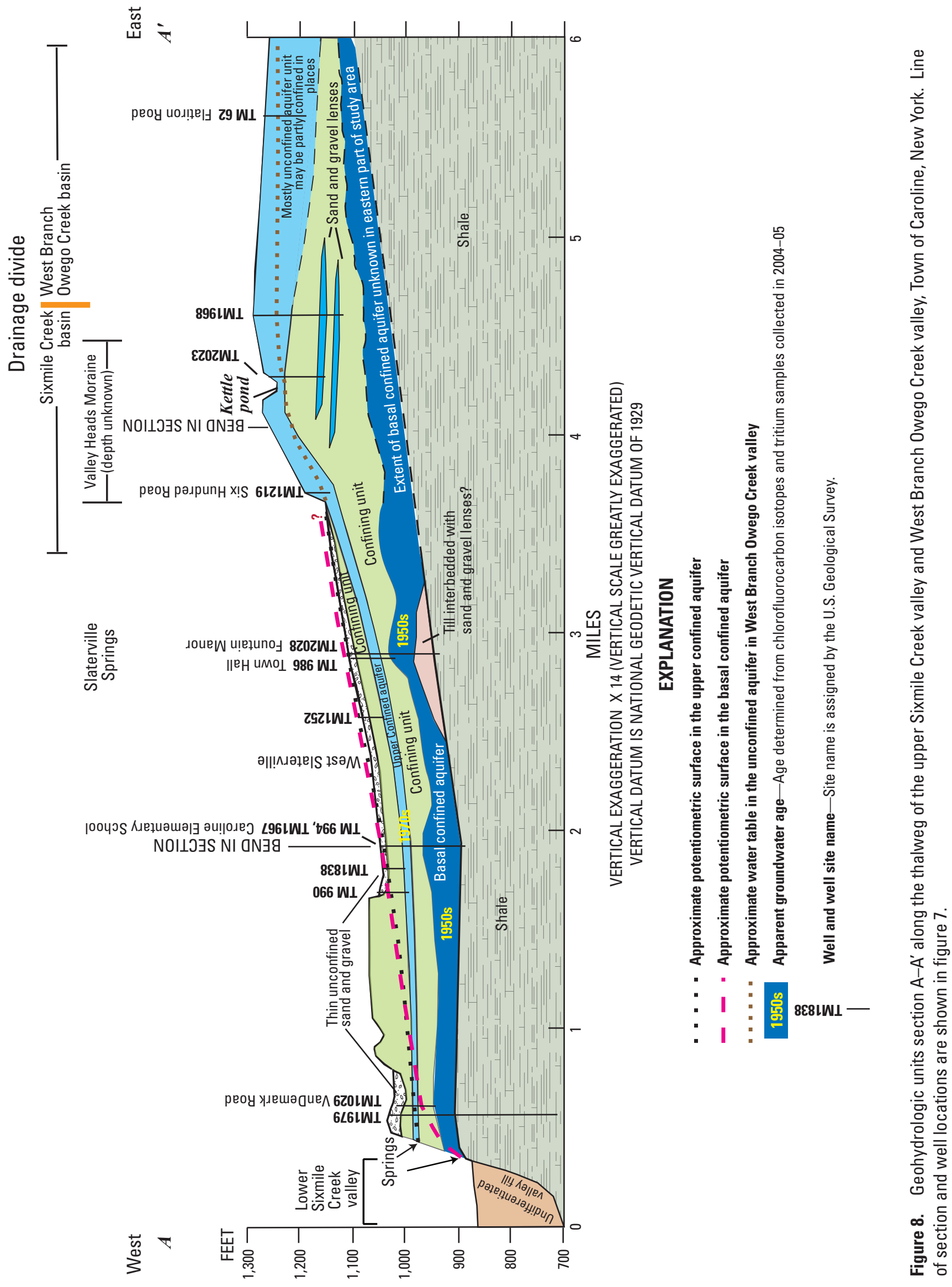


In the eastern part of the upper Sixmile Creek valley and in the headwaters of the West Branch Owego Creek valley, there is an unconfined aquifer as well as at least one confined aquifer unit that extend from the Valley Heads Moraine to the eastern boundary of the study area (figs. 7 and 8).

\section{Aquifer Geometry}

Characterizing aquifer geometry requires (1) mapping the extent and thickness of geohydrologic units, (2) distinguishing fine-grained deposits that form confining units from coarsegrained deposits that form aquifer units, (3) delineating contiguous units that have similar lithology and hydrologic properties (such as lacustrine deposits and till that are less transmissive than outwash, or kame sand and gravel deposits that are more transmissive), and (4) categorizing these deposits as either confining units or aquifer units. The aquifer geometry in the study area is complex due to multiple ice advances. Glacial and post-glacial erosion also substantially modified the upper parts of the valley fill. There are more well data in the shallower parts of the valley fill than in the deeper parts; therefore, the aquifer geometry is better defined in the shallower parts of the study area. The most productive aquifers in the western and central part of the upper Sixmile Creek valley are two confined sand and gravel units (figs. 7 and 8), whereas in the eastern part of the upper Sixmile Creek valley and in the headwaters of the West Branch Owego Creek valley, there is an unconfined aquifer as well as a confined or leaky confined aquifer.

Seismic-refraction surveys, well logs, and maps of geologic deposits were used to determine the geometry and thickness of the aquifers and confining units at selected locations. While seismic-refraction surveys may be useful for determining depths to saturated deposits and depths to the top of bedrock, they yield little data that can be used to differentiate between the various types of sediment that comprise the valley-fill deposits. However, results from seismic-refraction surveys combined with well logs and field observations made at geologic outcrops and exposures are valuable for describing the hydrogeologic framework of the aquifer system.

\section{Unconfined Aquifers}

An unconfined headwater aquifer extends from the Valley Heads Moraine in the central part of the study area to the outwash plain in the West Branch Owego Creek valley in the east part of the study area (figs. 7 and 8). Headwater aquifers are at major drainage divides (in this case the divide between the Susquehanna River basin and the Lake Ontario basin shown in fig. 4) and are not crossed by large perennial streams but are drained by small headwater streams. The unconfined headwater aquifer in the study area occupies a broad valley partially filled with stratified drift that was deposited when meltwater flowed across the watershed divide during deglaciation. The unconfined headwater aquifer consists mostly of coarse-grained deposits in the upper part of the valley fill, but lenses or bodies of fine-grained lacustrine sediment are also present. Throughout much of the year, the upland tributaries typically go dry where they cross the valley floor before joining the West Branch Owego Creek. Streamflow begins once the volume of recharge from upland runoff and direct precipitation on the valley floor exceeds the capacity of the upper, unconfined aquifer in the stratified drift to transmit water downvalley. Because the headwater of the West Branch Owego Creek valley does not contain a large, perennial stream, there is little potential for substantial recharge by induced infiltration from large pumping wells. However, the potential for recharge by induced infiltration from large pumping wells increases further downvalley (to the east) where the stream discharge becomes greater.

The Valley Heads Moraine has an irregular hummocky land surface with moderate relief, which contrasts with headwaters of the West Branch Owego Creek valley that drained away from the ice and where all or most of the valley floor consists of low planar surfaces such as flood plains and terraces that are commonly less than $20 \mathrm{ft}$ above stream level. East of the Valley Heads Moraine and in the West Branch Owego Creek valley, most homeowner and agricultural wells are shallow, ranging in depth from 25 to $90 \mathrm{ft}$. Well logs indicate that some wells are finished in an unconfined sand and gravel aquifer, but others indicate that a thin clay layer was penetrated. It is uncertain whether this thin clay layer is extensive and continuous enough to form a substantial confining unit, or if it is a discontinuous lens that is not an extensive confining bed.

Data from a deep test well (Climate Response Network well TM1968; well log shown in fig. 9; location shown in fig. 6) drilled in the outwash deposits just east of the crest of the Valley Heads Moraine indicate that the unconfined sand and gravel aquifer is $62 \mathrm{ft}$ thick, and there are two thin, confined aquifers at depths of 102 to $110 \mathrm{ft}$ (medium to coarse sand) and 135 to $140 \mathrm{ft}$ (sand and gravel). At well site TM1968, drilling was terminated in very fine sand at depth $170 \mathrm{ft}$; a deeper well would need to be drilled to determine whether a basal confined aquifer is present on top of bedrock. In well TM1968, the casing was backfilled with sediment and grout to a depth of $83.5 \mathrm{ft}$ and perforated from 55 to $58 \mathrm{ft}$ in the unconfined aquifer.

Well records in the West Branch Owego Creek valley indicate that the upper unconfined aquifer is at least 80 to $90 \mathrm{ft}$ thick, but there are no wells that extend to bedrock in the deepest part of the valley. Results from a seismic-refraction survey along Flatiron Road in the eastern part of the study area (figs. 6, 10A and 10B) indicated that depth to bedrock (thickness of unconsolidated deposits) was approximately $170 \mathrm{ft}$ at the southern end of the seismic line (near S1 in figs. 10A and 10B) and decreased northward to about $55 \mathrm{ft}$ to bedrock (near S6 in figs. 10A and 10B). However, there are no stratigraphic data on the types of valley-fill materials at depths greater than $90 \mathrm{ft}$. 


\section{U.S. Geological Survey Climate Response Network Well TM1968}

Well located 1 mile east of Slaterville Springs, NY

Well site name: TM1968
Site ID: 422323076190301
Latitude: $42^{\circ} 23^{\prime} 22.80^{\prime \prime}$
Longitude: $076^{\circ} 19^{\prime} 03.03^{\prime \prime}$

Altitude of land surface 1,278.2 feet

above National Geodetic Vertical Datum of 1929

Sand and gravel, brown, fine to coarse pebbles,

some cobbles, subround to round clasts, medium

to coarse sand with some fine sand, moist

15

Sand and gravel, brown, fine to coarse pebbles, some cobbles, subround to round clasts, medium coarse sand with some fine sand, wet

Some zones consist mostly of medium to coarse sand

Sand and gravel, brown, fine to coarse pebbles, some cobbles, subround to round clasts, medium to coarse sand with some fine sand, wet, makes water at approximately 10 gallons per minute

湈

$$
110
$$

Pebbly sand, medium to coarse sand, fine pebbles

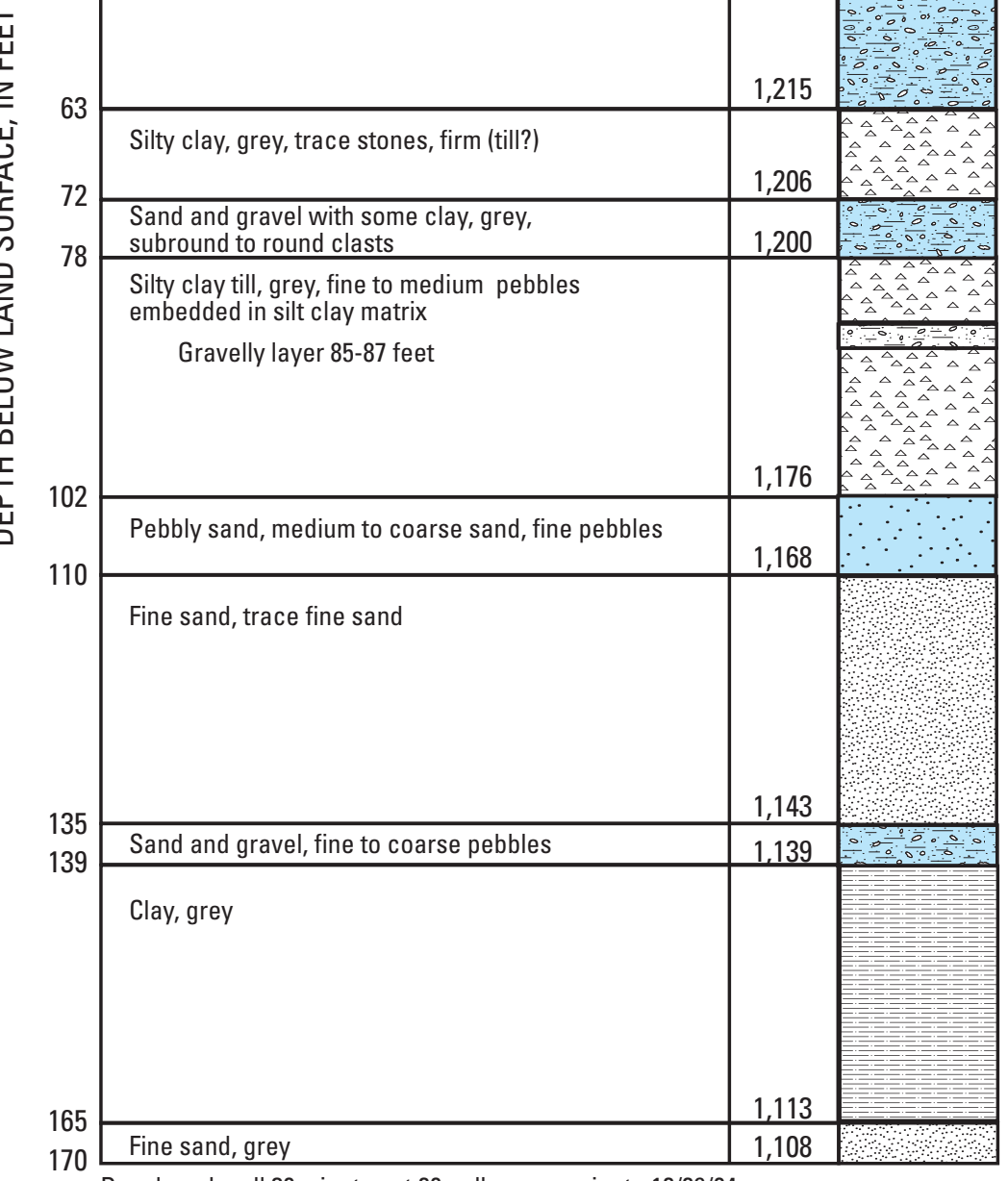

Developed well 30 minutes at 20 gallons per minute 12/29/04 Altitude
Date completed: 12/29/04

Drilling contractor: Barber \& DeLine, Tully, NY

Well depth: 58 feet (6-inch-diameter casing)

Casing: 6 -inch diameter steel casing

Altitude top of casing $=1,280.69$ feet Casing above ground $=2.5$ feet 


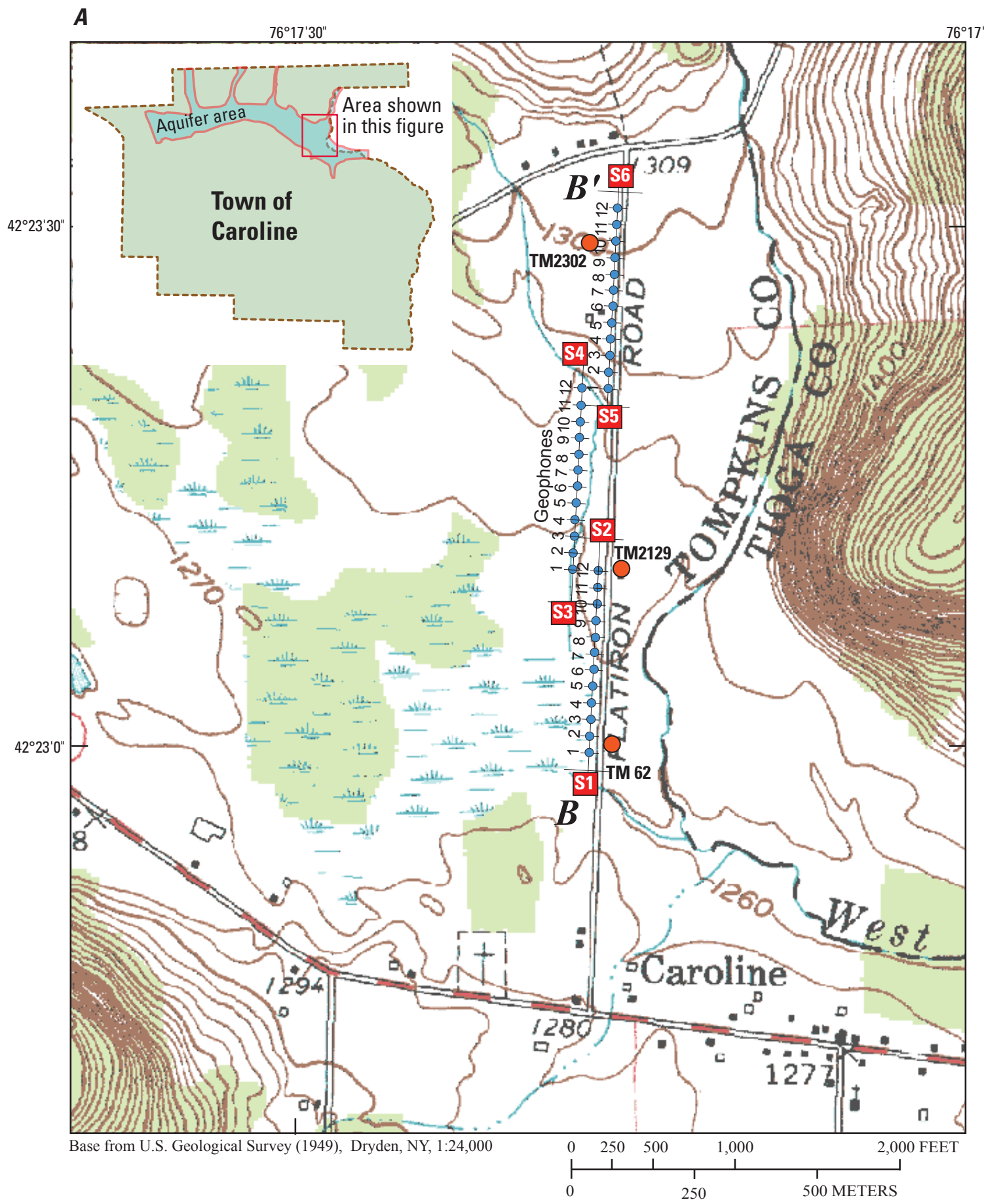

EXPLANATION

Seismic-refraction survey line Geophones

123456789101112

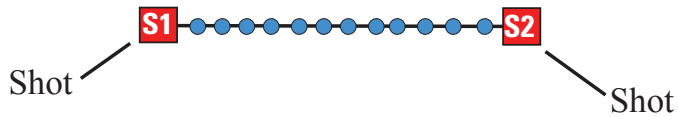

TM 62 Well and well site name-Site name is assigned by the U.S. Geological Survey. Well data are in Appendix 1 at end of report

Figure 10. Seismic-refraction survey B-B' along Flatiron Road, Town of Caroline, New York: $(A)$ location of line of section, and $(B)$ seismic profile. 


\section{B}

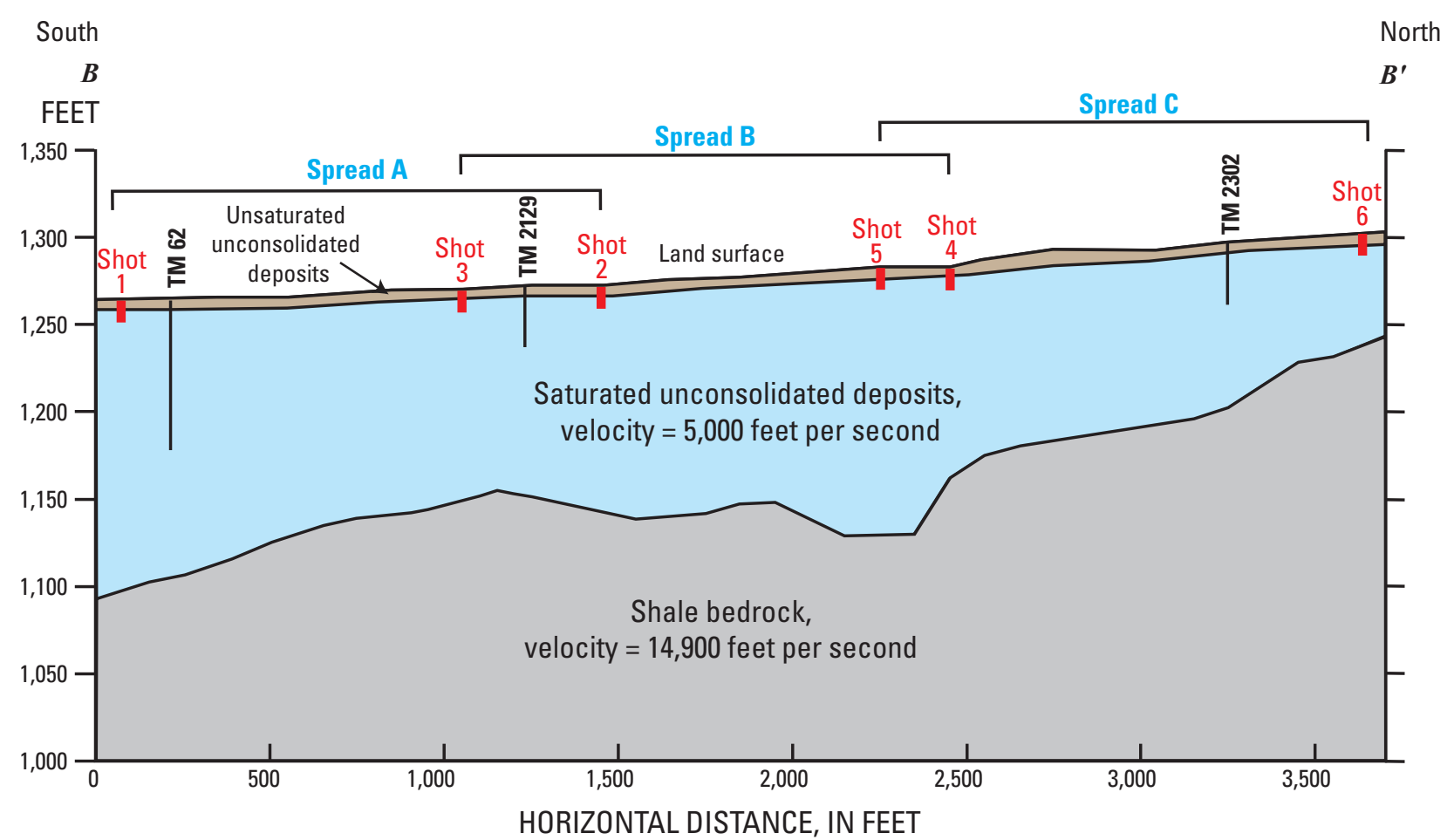

VERTICAL EXAGGERATION X 5

VERTICAL DATUM IS NATIONAL GEODETIC VERTICAL DATUM OF 1929

\section{EXPLANATION}

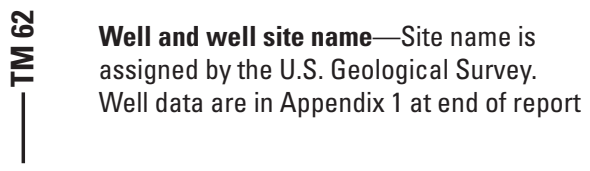

Figure 10. Seismic-refraction survey B-B' along Flatiron Road, Town of Caroline, New York: $(A)$ location of line of section, and $(B)$ seismic profile.-Continued

Thin (10 to $20 \mathrm{ft}$ thick) alluvial, deltaic, and outwash sand and gravel deposits on the surface in low-lying areas in the central to western parts of the upper Sixmile Creek valley may form discontinuous unconfined aquifers (figs. 5 and 7). These thin, discontinuous aquifers generally are not reliable sources of water during drier periods of the year (especially droughts), when part, or all, of these aquifers may go dry. Springs that discharge from the aquifers at the base of the steep deltaic bluffs at Brooktondale (fig. 7) are used to supply water to several homes and apartment units.

\section{Confined Aquifers and Confining Units}

Two confined aquifers constitute the major water-bearing units in the western part of upper Sixmile Creek valley (figs. 7 and 8). One or more confined aquifers may also be present beneath the unconfined aquifer in the eastern part of the study area (beneath the Valley Heads Moraine and West Branch Owego Creek valley), but there are little data for the deeper parts of the valley fill in this area to confirm this possibility.

Results of two seismic-refraction surveys in the western part of the study area (figs. 11A, 11B, and 11C) indicated that (1) along seismic profile $\mathrm{C}-\mathrm{C}^{\prime}$ north of Landon Road (fig. 11B) the valley-fill deposits are about $80 \mathrm{ft}$ thick at the northern end of the line at $\mathrm{C}^{\prime}$ and thicken southward to about $100 \mathrm{ft}$ at $\mathrm{C}$, and (2) along VanDemark Road (seismic profile D-D') (fig. 11C) the valley-fill deposits are about $100 \mathrm{ft}$ thick at the northern end of the line (around the 1,800-ft mark) and thicken slightly southward to about $120 \mathrm{ft}$ (around the 1,500-ft mark), before thinning to about $110 \mathrm{ft}$ further southward to the end of the line (around the 1,000-ft mark). 


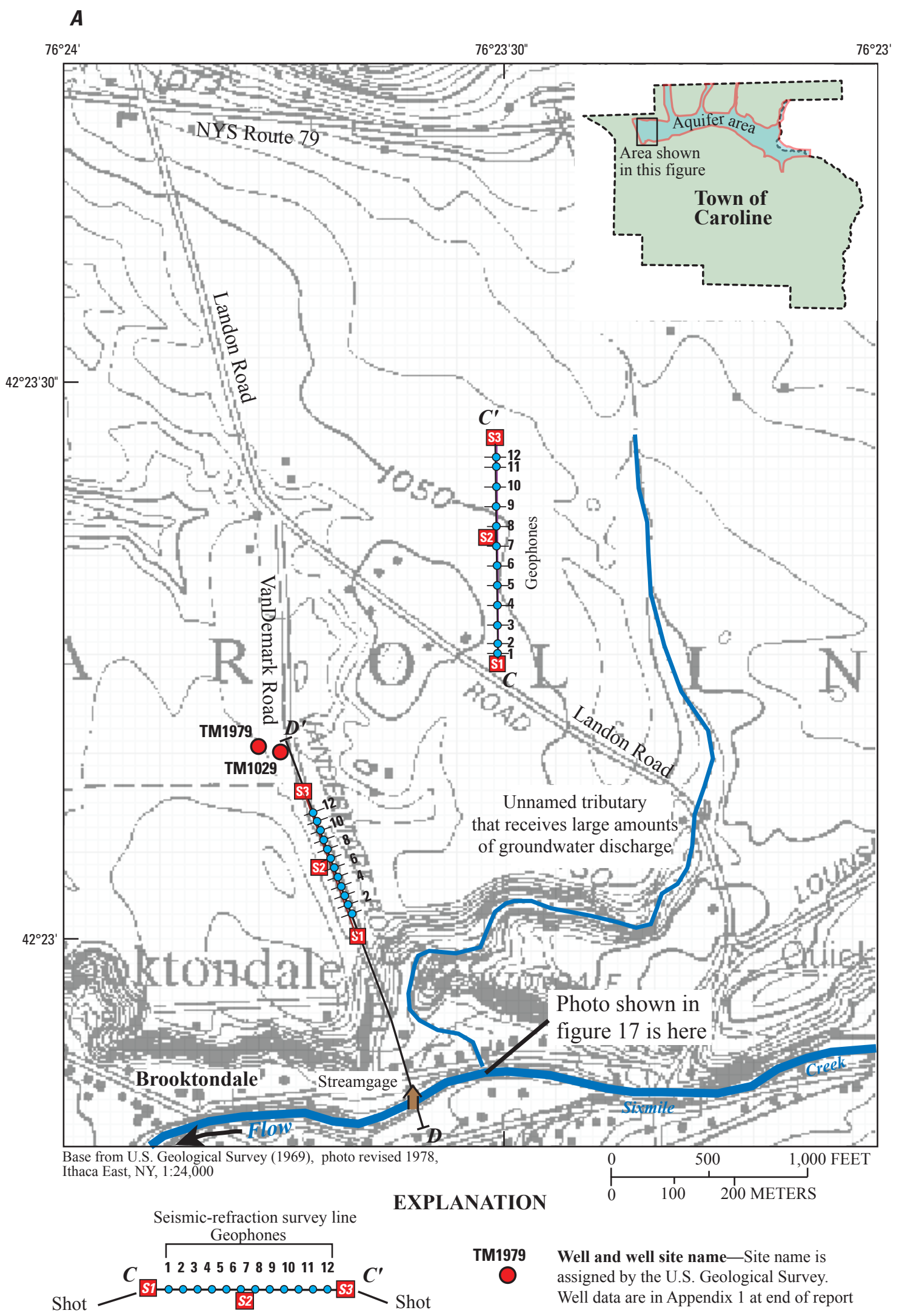

Figure 11. Seismic-refraction surveys, Town of Caroline, New York: $(A)$ location of surveys $C-C^{\prime}$ (north of Landon Road) and D-D' (along VanDemark Road) in upper Sixmile Creek valley, $(B)$ seismic profile C-C' north of Landon Road, and (C) geohydrologic section D-D' along VanDemark Road. 


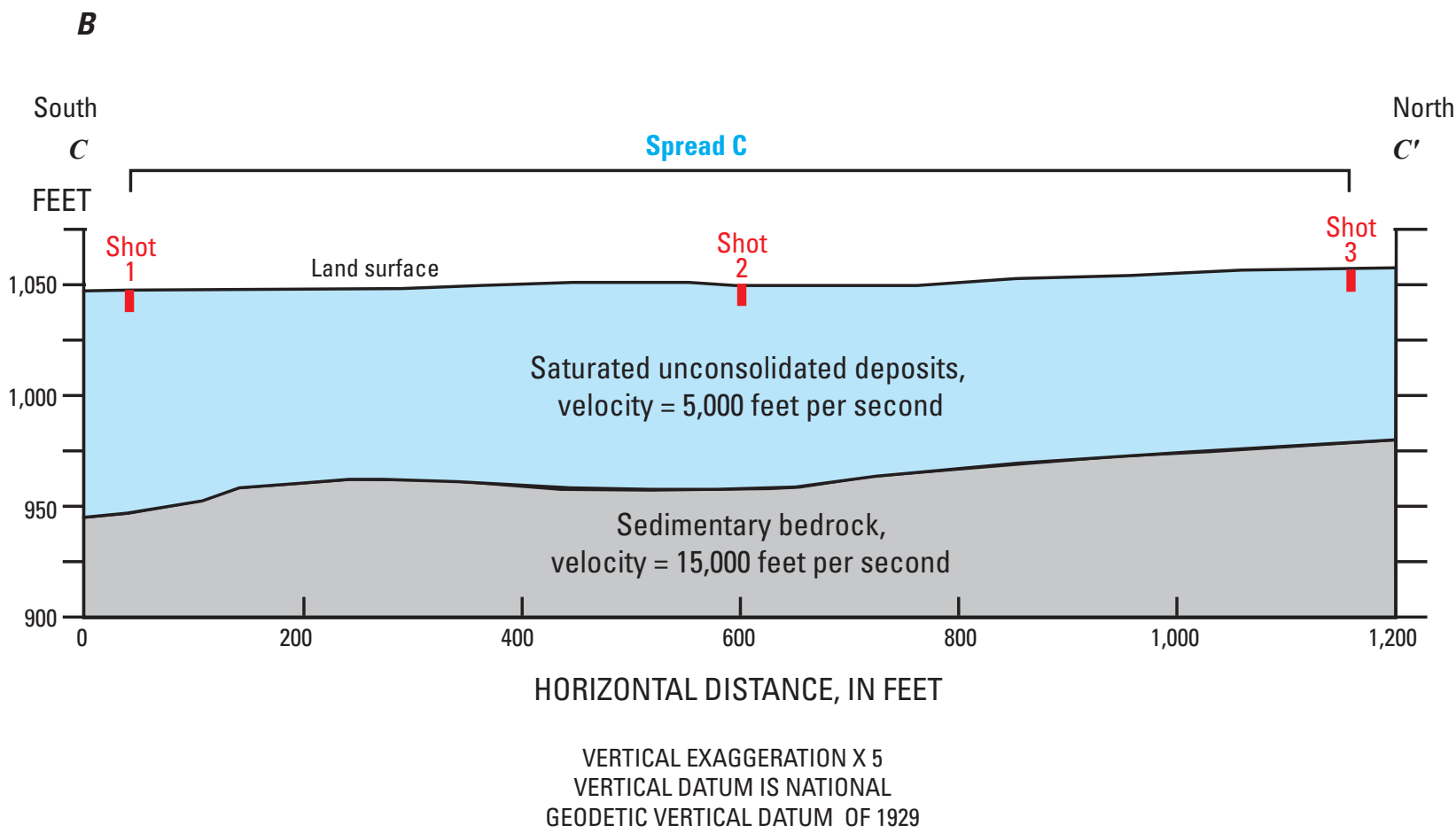

Figure 11. Seismic-refraction surveys. Town of Caroline, New York: $(A)$ location of surveys $C-C^{\prime}$ (north of Landon Road) and D-D' (along VanDemark Road) in upper Sixmile Creek valley, (B) seismic profile C-C' north of Landon Road, and $(C)$ geohydrologic section D-D' along VanDemark Road.-Continued

The upper confined aquifer is generally 25 to $50 \mathrm{ft}$ below land surface. The thickness of the unit typically ranges from 5 to $15 \mathrm{ft}$. The upper confined aquifer is overlain by a 15- to 30-ft-thick confining unit that consists of a clay till in the eastern part of the upper Sixmile Creek valley and glaciolacustrine silt and very fine sand in the western part of the valley. The confining unit is believed to be extensive in the valley. In upper Sixmile Creek valley, many homeowner wells (mostly drilled wells but also some driven wells) and the well (TM 73) that supplies the Caroline Elementary School tap this aquifer. The aquifer is under artesian flowing conditions in the low areas between Slaterville Springs and West Slaterville (fig. 8). West of West Slaterville, the aquifer is under confined conditions but not flowing-artesian conditions.

The basal confined aquifer typically ranges from 75 to $100 \mathrm{ft}$ below land surface in most places in the upper Sixmile Creek valley. The thickness of the aquifer is largely unknown because most water-well drillers finish wells in either the upper confined aquifer or in the basal confined aquifer and do not extend to the bottom of the basal aquifer. The particle size of the sediments that comprise the basal confined aquifer varies greatly from place to place. At the Caroline Elementary School, the basal aquifer was $83 \mathrm{ft}$ thick but was poorly sorted in places, consisting of large amounts of sand as well as some gravel. The aquifer is overlain by a 30 - to 50 -ft-thick confining unit that consists of glaciolacustrine very fine sand, silt, and clay. The confining unit is believed to be fairly extensive and thick in the central parts of the valley, but the unit thins towards the edges of the valley where it may pinch out in places. Many wells in the upper Sixmile Creek valley are also finished in the basal confined aquifer, including the Town Hall well (TM 986) in Slaterville Springs (fig. 6), which is a flowing artesian well.

It is unknown whether the basal aquifer extends beneath the Valley Heads Moraine and into the West Branch Owego Creek valley in this study area. However, basal sand and gravel aquifers are common in front of the Valley Heads Moraine in other valleys in central New York (Miller and others, 1998; Kappel and Miller, 2003).

\section{Bedrock Aquifers}

The upper Sixmile Creek basin is underlain by Devonianage sedimentary rock units consisting mostly of shales and siltstones. Water movement is controlled by secondary permeability in the joints or fractures in the rock and typically predominates along bedding planes. Few wells in Tompkins County penetrate more than about $300 \mathrm{ft}$ into the sedimentary rock units, and little hydrologic information is available beyond that depth. Generally, water-well drillers do not drill wells greater than $300 \mathrm{ft}$ deep because water becomes increasingly more mineralized and less potable with depth. 


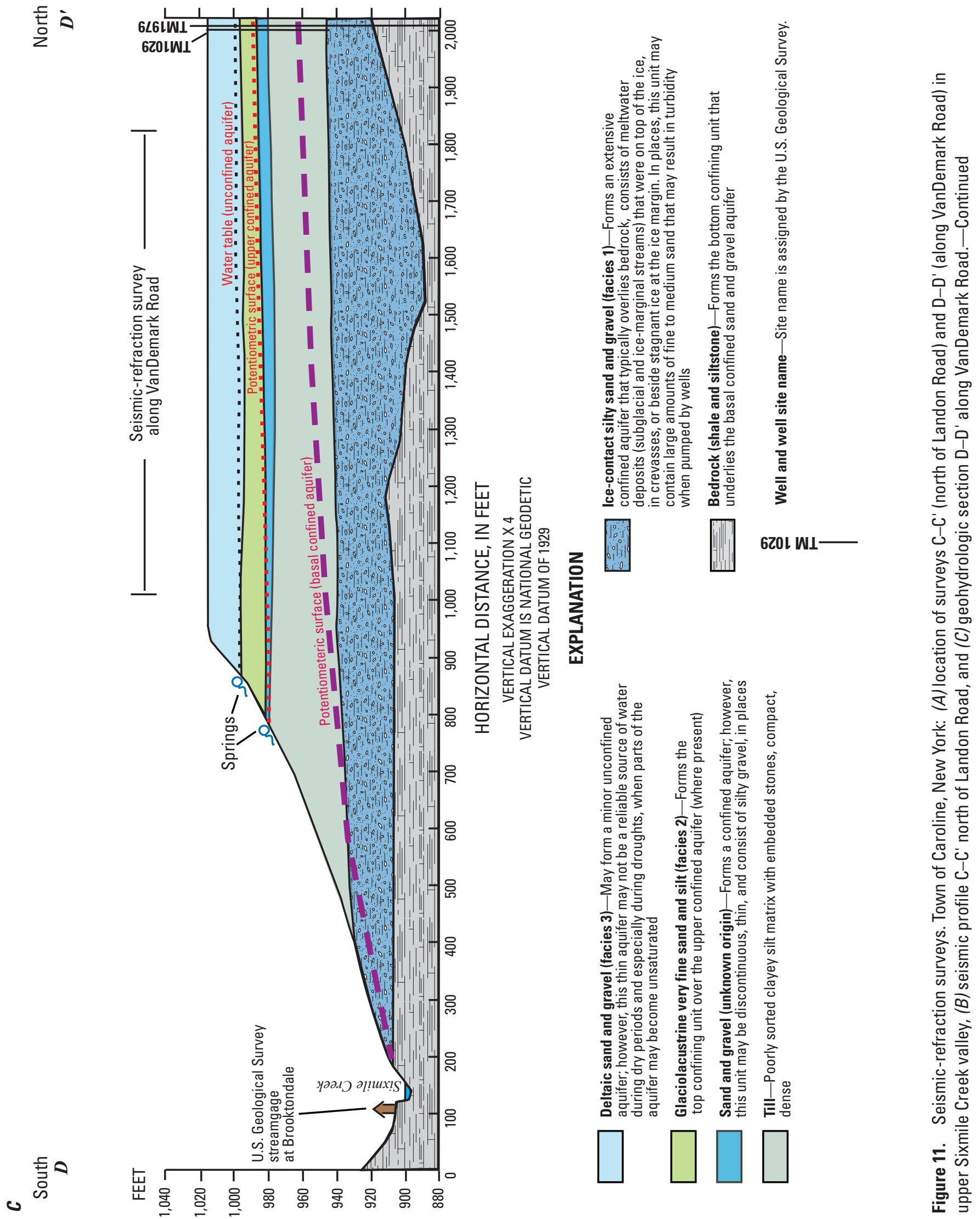


In sedimentary rocks in Connecticut, the number of joints, fractures, and bedding-plane openings typically decreases with depth (Olcott, 1995); permeability of the rock units similarly decreases until groundwater movement is extremely slow or ceases at some depth. Decreased circulation of groundwater results in an increase of dissolved minerals in the water and at some depth the water becomes nonpotable. Brackish water in Devonian-age rocks is ubiquitous throughout central and western New York and is typically no more than 100 to $150 \mathrm{ft}$ below large tributary and major valley floors (A.D. Randall, U.S. Geological Survey, written commun., 2008). The density, width of opening, and connectiveness of water-bearing fractures has not been investigated for bedrock geohydrologic units in this study area.

Bedrock aquifers are important water resources in the region because they are present everywhere, even though the yields available from individual bedrock wells completed in bedrock wells are generally much lower than from wells finished in sand and gravel. In the uplands, bedrock is both the sole dependable source as well as the most economical source of potable water for homes, commercial establishments, and small public-supply systems. Specific capacity, a measure of the number of gallons per minute pumped per foot of drawdown in a well, was computed for 66 bedrock wells in south-central New York and averaged $0.46(\mathrm{gal} / \mathrm{min}) / \mathrm{ft}$ (Kontis and others, 2004) for shale and siltstone geohydrologic units, which is generally at least a magnitude in order less than that for sand and gravel aquifers. In the upper Sixmile Creek basin, water-well drillers' logs indicate that yields of 2 to $5 \mathrm{gal} / \mathrm{min}$ can usually be obtained from wells that tap bedrock at most locations and, occasionally, yields as large as 10 to $30 \mathrm{gal} / \mathrm{min}$ and yields less than $1 \mathrm{gal} / \mathrm{min}$ are reported (table 1 ). Water withdrawn from bedrock aquifers constitutes a large percentage of total groundwater withdrawals from the upper Sixmile Creek basin.

\section{Groundwater Levels and Flow Paths}

In the part of the study area where the valley-fill aquifer is unconfined, recharge and discharge can occur simultaneously at varying rates such that storage is either increasing (rising groundwater levels) or decreasing (declining water levels). Patterns in water-level fluctuations differ from place to place as a function of aquifer type, hydraulic conductivity of the aquifer, and distance to the nearest discharge or recharge areas such as streams or pumping wells. For example, in the permeable unconfined aquifer, the water table is generally within a few feet of stream stage in West Branch Owego Creek and fluctuates similarly to the water level in the stage in the stream. In distal areas from the stream, the water table is several feet above the stream, and annual water-level trends are largely affected by fluctuations in precipitation.

Natural changes in storage, as reflected by fluctuations in the water table, generally follow seasonal patterns. These include short, relatively well-defined periods of increased storage in the spring and late fall, when recharge to the aquifer exceeds discharge from the aquifer, and longer, poorly defined periods of decreased storage in the summer and winter, when discharge generally exceeds recharge. Also, a regional drought that reduces recharge over a large area can result in reduced storage and yield from sand and gravel aquifers in the affected area.

The water table in the unconfined aquifer, the potentiometric surface in the upper confined aquifer, and the general direction of groundwater flow in both aquifers are shown in figure 12. The water-table map was constructed using 16 water-level measurements made by water-well drillers during the years 2002-07, by USGS personnel during this investigation (2002-06), and during a previous study by Randall and others (1988). Also, altitudes of perennial streams and of ponds and wetlands that are connected to the unconfined aquifer were also used to construct the water-table

Table 1. Range, mean, and median reported well yields and well depths in the Sixmile Creek and West Branch Owego Creek valley-fill aquifer, Town of Caroline, New York.

[Data reported from water-well drillers. gal/min, gallons per minute; ft, feet]

\begin{tabular}{|c|c|c|c|c|c|c|c|c|c|}
\hline \multirow[b]{2}{*}{ Aquifer type } & \multicolumn{4}{|c|}{ Well yields } & \multicolumn{4}{|c|}{ Well depths } & \multirow{2}{*}{$\begin{array}{c}\text { Number } \\
\text { of } \\
\text { artesian } \\
\text { flowing } \\
\text { wells }\end{array}$} \\
\hline & $\begin{array}{c}\text { Number } \\
\text { of } \\
\text { wells }\end{array}$ & $\begin{array}{c}\text { Range } \\
\text { (gal/min) }\end{array}$ & $\begin{array}{c}\text { Mean } \\
\text { (gal/min) }\end{array}$ & $\begin{array}{c}\text { Median } \\
\text { (gal/min) }\end{array}$ & $\begin{array}{c}\text { Number } \\
\text { of } \\
\text { wells }\end{array}$ & $\begin{array}{c}\text { Range } \\
\text { (ft) }\end{array}$ & $\begin{array}{c}\text { Mean } \\
\text { (ft) }\end{array}$ & $\begin{array}{c}\text { Median } \\
\text { (ft) }\end{array}$ & \\
\hline Unconfined sand and gravel & 11 & $7-50$ & 18.3 & 15 & 17 & $20-90$ & 41.8 & 35 & 0 \\
\hline Confined sand and gravel & 18 & $5-30$ & 14.6 & 12 & 31 & $29-138$ & 64.5 & 57 & 5 \\
\hline Bedrock & 17 & $1-30$ & 8.4 & 6 & 22 & 59-300 & 148.6 & 135 & 1 \\
\hline
\end{tabular}




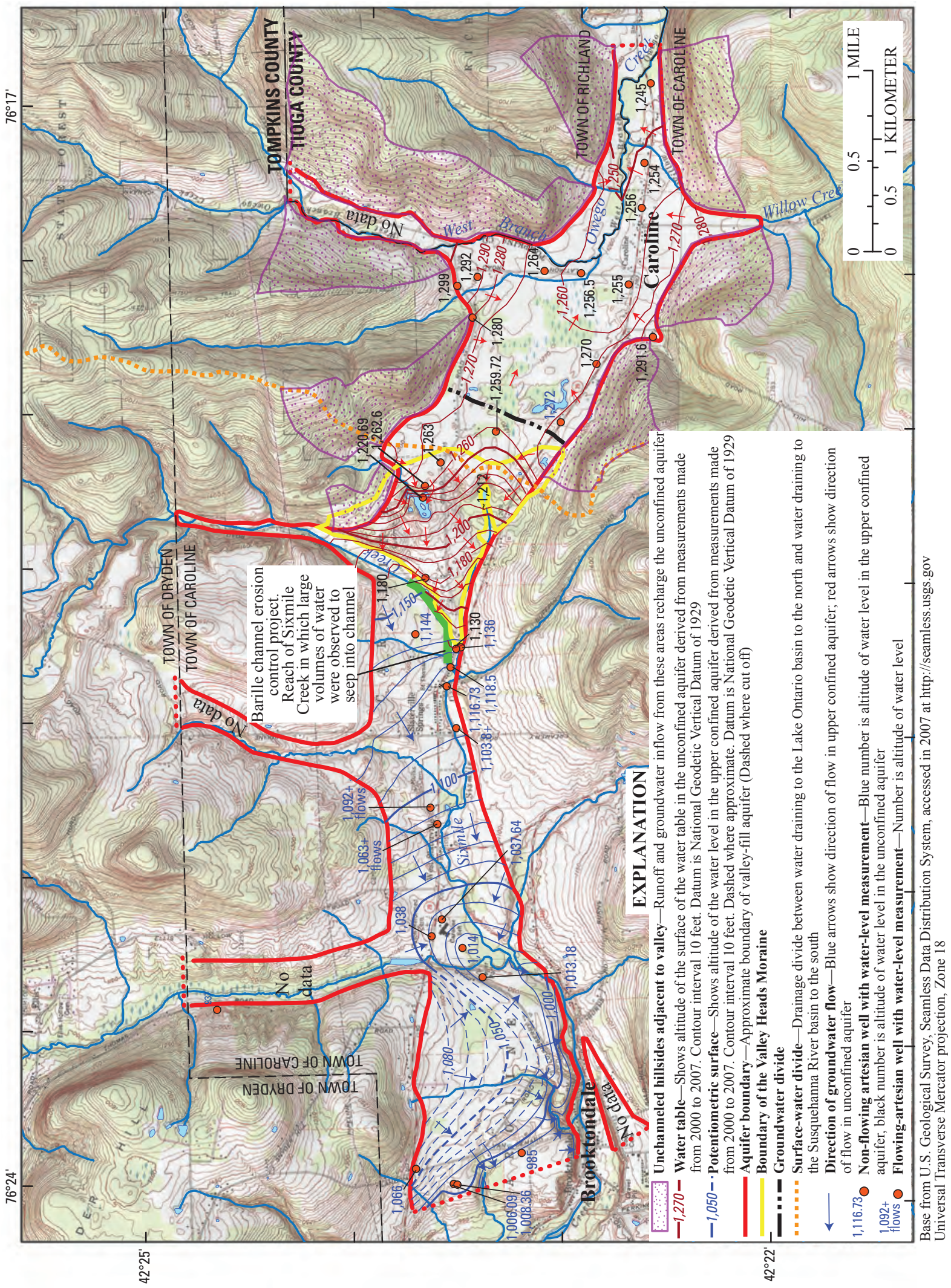

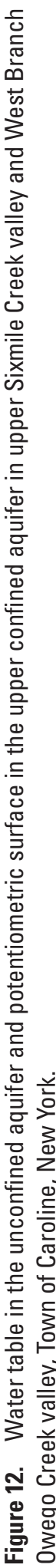


contours. Although water-level measurements from Randall and others (1988) were from a previous period, the average annual fluctuation is only expected to be about $5 \mathrm{ft}$ in most of the low-lying areas because surface-water features such as large wetlands and streams are widespread throughout the valley floor in the eastern part of the aquifer (fig. 5). In other valleys that contain the Valley Heads Moraine and where groundwater studies have been conducted, these surfacewater bodies (wetlands, kettle ponds, and streams), and the groundwater in the vicinity of these surface-water bodies, have water levels that typically fluctuate less than $5 \mathrm{ft}$ during the year (Kappel and others, 2001; Miller and Staubitz, 1985).

Also, the annual water-level fluctuation was less than $5 \mathrm{ft}$ in the western part of the study area where, in well TM 984, the difference in water levels during a period of low-level conditions in the late fall (depth to water level below land surface was $13.44 \mathrm{ft}$ on December 12, 2002) and high water-level conditions after winter snowmelt (depth to water level below land surface was $10.90 \mathrm{ft}$ on March 24, 2003, Appendix 1) was $2.54 \mathrm{ft}$. However, in more distal areas from surface-water features and near the groundwater divide in the Valley Heads Moraine, annual fluctuations in the water table typically range from 5 to $10 \mathrm{ft}$ as evidenced by fluctuations in water levels in a test well completed for this study (see section on "Climate Response Network Well"). By using a 10-ft contour interval for the water table and allowing for annual water-level fluctuation of approximately $5 \mathrm{ft}$ in most places, the configuration of the water-table map that was generated provides a reasonable representation of average annual watertable conditions.

A groundwater divide in the central part of the study area (fig. 12) separates groundwater flow that moves westward into the Lake Ontario basin from that flowing eastward into the Susquehanna River basin. The groundwater divide does not exactly coincide with the surface-water divide (fig. 12), which is not an uncommon situation in other valleys in central New York where the Valley Heads Moraine is found, such as in Tully Valley, NY (Kappel and others, 2001). Groundwater in the unconfined aquifer on the east side of the Valley Heads Moraine generally flows from the edges of the aquifer toward the central part where it discharges into a large wetland and eventually the West Branch Owego Creek.

The potentiometric surface in the upper confined aquifer was determined through 14 water-level measurements made during this investigation by water-well drillers during the years 2002-07 and by USGS personnel during this investigation (2002-08). Groundwater in the upper confined aquifer (fig. 8) is under artesian conditions or artesian-flowing conditions except where it discharges to springs along bluffs in the western end of the aquifer (figs. 7, 8, and 12).

The potentiometric surface in the basal confined aquifer was determined through 11 water-level measurements made during this investigation by water-well drillers during the years 2002-07 and by USGS personnel during this investigation (2002-08). Groundwater in the basal confined aquifer in upper Sixmile Creek valley flows westward from the Valley Heads Moraine under artesian conditions, where it discharges to streams and springs along bluffs at the western edge of the aquifer (figs. 7, 8, and 13). Most wells in the low-lying areas near Slaterville Springs and West Slaterville, NY, that tap the confined aquifers are under artesian-flowing conditions with hydraulic heads about 5 to $20 \mathrm{ft}$ above land surface, but other wells that are several tens of feet higher on terraces and kames along the valley walls do not flow, although they too are artesian. The existence or absence of a basal aquifer in West Branch Owego Creek valley was not determined. However, basal aquifers are common in other major valleys in central New York, so it is probable that there is one in the West Branch Owego Creek as well. Sources of recharge to the basal confined aquifer are uncertain. One likely source of recharge is from groundwater in the underlying bedrock that probably flows to the basal aquifer in the bottom and along the sides of the valley.

In December 2004, a hole was bored at the Caroline Elementary School (figs. 6 and 7) to a depth of $170 \mathrm{ft}$ to determine the stratigraphy of the valley-fill deposits and vertical hydraulic gradients in geohydrologic units, and to collect groundwater samples. Bedrock was penetrated at a depth of $160 \mathrm{ft}$ and a nested pair of wells (TM 994 and TM1967) was installed at two confined aquifer zones (fig. 14). Well TM 994 is $39 \mathrm{ft}$ deep and is finished in the upper confined aquifer, and well TM1967 is $92 \mathrm{ft}$ deep and is finished in the basal confined aquifer. On January 13, 2005, and July 18, 2005, the water levels in these wells differed by only 1.1 and $1.2 \mathrm{ft}$, in altitude, respectively, with the deeper well (TM1967) having a higher hydraulic head than the shallow well (TM 994). The water-level altitudes for wells TM1967 and TM 994 on January 13, 2005, were 1,041.2 and $1,040.1 \mathrm{ft}$, respectively; on July 18, 2005, they were 1,038.9 and $1,037.7 \mathrm{ft}$, respectively. The higher hydraulic head in the basal confined aquifer indicates that there is an upward hydraulic gradient in this area from the basal to the upper confined aquifer.

At the western edge of the upper Sixmile Creek valley, the heads in the upper confined aquifer and in the basal confined aquifer differ by several tens of feet because the altitudes of the discharge areas have a large effect on heads in the aquifers in that area (figs. 8 and 11C). In the vicinity of Brooktondale, NY, groundwater discharges from the basal aquifer at the sand and gravel/bedrock contact at the base of the bluff, whereas groundwater in the upper aquifer discharges at the sand and gravel/till contact 60 to $70 \mathrm{ft}$ higher up the bluff (figs. 8 and 11C).

\section{Climate Response Network Well}

The USGS, in cooperation with the New York State Department of Environmental Conservation, collects waterlevel data nationwide from wells in the USGS Climate Response Network (CRN). In 2006, the Climate Response Network contained more than 500 wells nationwide, and beginning on December 30, 2004, well TM1968 


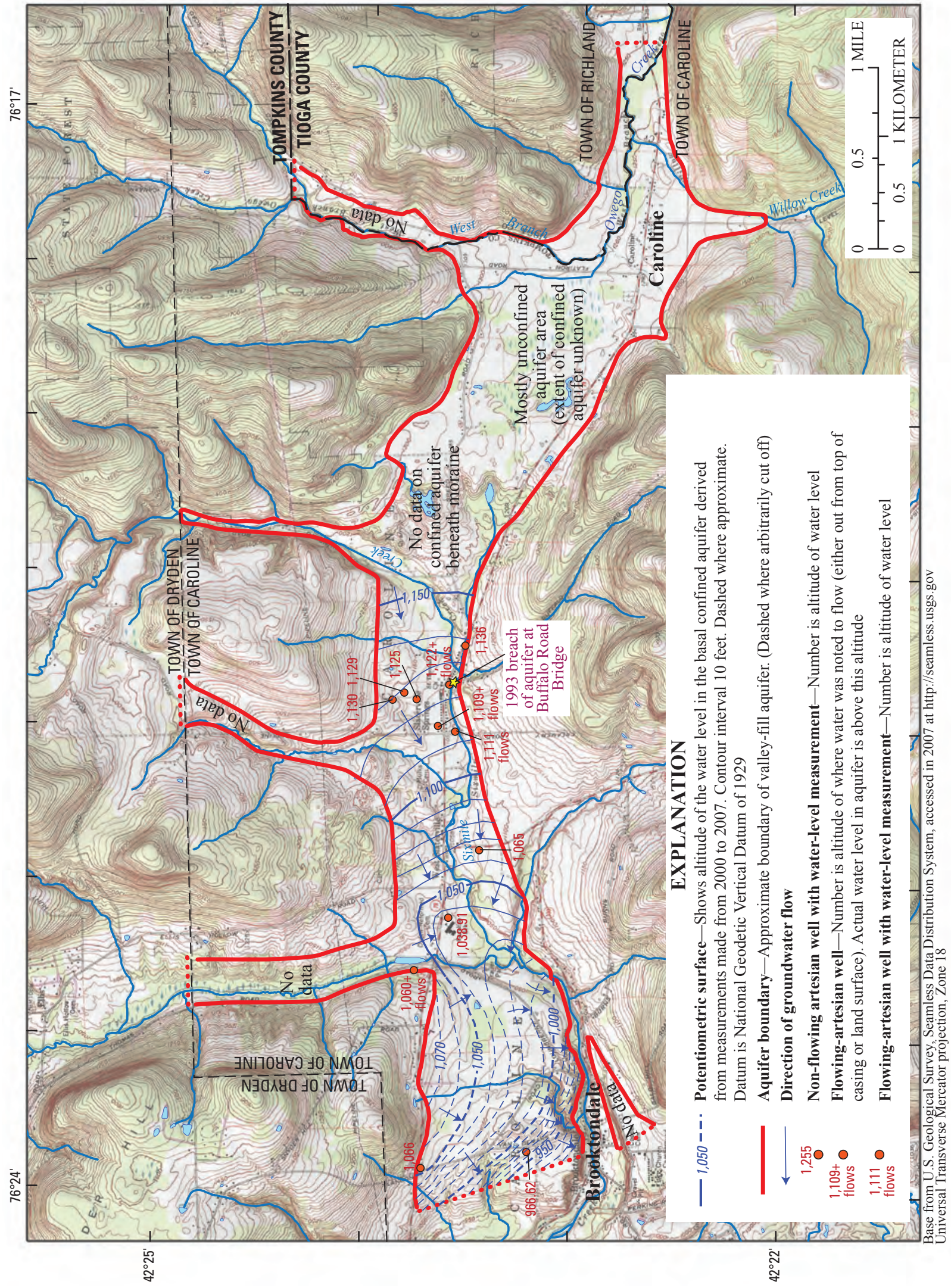

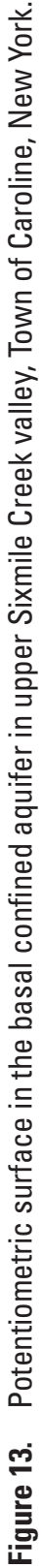




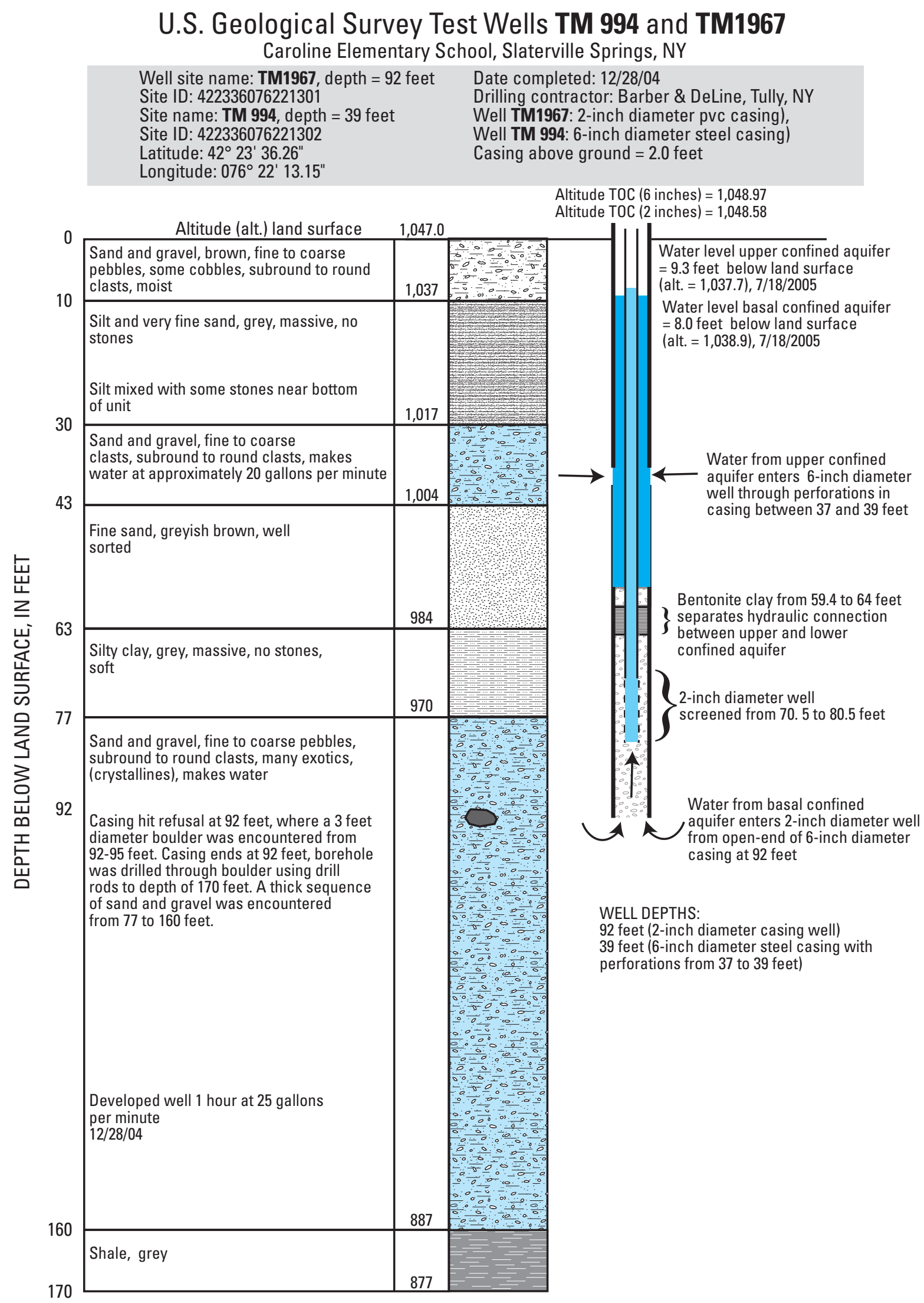

Figure 14. Well log and construction details of U.S. Geological Survey test wells TM 994 and TM1967 at Caroline Elementary School near Slaterville Springs, New York. 
(figs. 6, 7, and 9) in the Town of Caroline, NY, about $1 \mathrm{mi}$ east of Slaterville Springs, NY, became part of that network. The casing of well TM1968 is perforated from 55 to $58 \mathrm{ft}$ below land surface and open to the unconfined sand and gravel aquifer (fig. 9). The primary purpose of the CRN is to portray the effects of climate on groundwater levels in unconfined aquifers or near-surface confined aquifers that are minimally affected by pumping or other anthropogenic stresses. The CRN web site (http://groundwaterwatch.usgs.gov/) provides users with current groundwater conditions throughout the United States and allows users to view and retrieve past waterlevel data for network wells.

Water levels in well TM1968 are recorded on an hourly basis and can be retrieved and plotted on a hydrograph at the site web page: http:/groundwaterwatch.usgs.gov/ CRNSites.asp?S=422323076190301. The site page also has information related to an individual well such as location, well depth, and aquifer type. When more than 4 years of data (by 2009) and less than 10 years of data are collected, the minimum, median, and maximum water levels are displayed. When more than 10 years of data (by 2014) have been collected, water-level percentiles are computed and displayed in addition to monthly statistics that are depicted on a monthly bar chart. This chart provides a powerful statistical combination of historical data with recent measurements. After 10 years of record are collected, water-level measurements from the most recent 12-month period are plotted on an annual statistical hydrograph, providing current groundwater conditions compared to historical groundwater conditions for any given month.

The water level below land surface from January 1 , 2005, through December 31, 2007, in CRN well TM1968 is shown in the hydrograph in figure 15 . During this period, the maximum fluctuation of the water table was $9.7 \mathrm{ft}$, with the lowest water level at $20.4 \mathrm{ft}$ below land surface on October 15, 2005, and the highest water level at $10.7 \mathrm{ft}$ below land surface on April 5, 2005.

\section{Groundwater Recharge}

The amount of recharge to stratified-drift aquifers is a key determinant of the long-term availability of water. More recharge water is available to unconfined sand and gravel aquifers than to confined aquifers.

\section{Unconfined Aquifers}

Recharge derived from upland sources provides a substantial percentage of total recharge to the unconfined aquifers in upper Sixmile Creek and West Branch Owego Creek valleys. Sources of recharge to the unconfined aquifers include (1) precipitation (rain and snowmelt) that falls directly on the land surface above the stratified drift and infiltrates to the saturated zone; (2) unchanneled runoff from upland hillsides immediately adjacent to the stratified drift, flowing downhill as surface or shallow subsurface runoff during and after storms; (3) infiltration from the upland stream channels where they cross the stratified drift and lose water to the aquifer; and (4) groundwater inflow from adjacent till or bedrock (fig. 16).

\section{Direct Infiltration of Precipitation on the Valley Floor}

A major source of recharge to the unconfined aquifers in the study area is direct infiltration of precipitation into the saturated zone. Runoff is generally negligible over undeveloped areas of sand and gravel, so all precipitation that is not lost to evapotranspiration recharges the unconfined aquifer. Evapotranspiration includes evaporation, in which water is changed from liquid into vapor, and transpiration by which water vapor escapes from living plants back into the atmosphere. In the southeastern part of Tompkins County, the annual evapotranspiration is estimated to range between 19 and 20 in. (Kontis and others, 2004, plate 1). This amount is roughly equivalent to half of the annual precipitation in this area based on the mean-annual precipitation for 1995-2006 at the National Weather Service station at Cornell University, which was about 40 in. (the annual recharge to the unconfined aquifer in the study area by direct infiltration is about 20 in., or half the mean annual precipitation). Therefore, the average annual recharge from precipitation that falls directly over the unconfined aquifer may be estimated by multiplying the area of the unconfined aquifer $2.38 \mathrm{mi}^{2}\left(6.58 \times 10^{7} \mathrm{ft}^{2}\right)$ by the annual rate of precipitation minus evapotranspiration, $20 \mathrm{in} / \mathrm{yr}$ $(1.67 \mathrm{ft} / \mathrm{yr})$, which yields a recharge rate of $1.11 \times 10^{8} \mathrm{ft}^{3} / \mathrm{yr}$ or $3.54 \mathrm{ft}^{3} / \mathrm{s}(2.29 \mathrm{Mgal} / \mathrm{d})$.

The hydrograph (a plot of water level versus time) depicted for well TM1968 in figure 15 illustrates when recharge occurred in the unconfined aquifer in the study area. Periods of recharge (when groundwater storage in the aquifer is increasing) are represented by rising groundwater levels; this occurs mostly during late fall, winter, and early spring, just before and just after the growing season (fig. 15). Little recharge occurred during the growing season from late spring to early fall in 2005 and 2007, when the evapotranspiration rate typically exceeds the precipitation rate and when these were periods of below-normal precipitation. In 2006, however, there were several periods of above-normal precipitation during the summer and fall in which the rate of infiltration exceeded the rate of evapotranspiration, resulting in several spikes in groundwater levels during the summer and fall. Large rises in groundwater levels such as those observed in well TM1968 during the growing season (May through October) are uncommon in central New York.

Not all of the unconfined aquifer in the West Branch Owego Creek valley receives recharge from direct infiltration of precipitation because the precipitation that falls on areas with a high water table, such as the large wetland in the central part of the West Branch Owego Creek valley, is rejected by the groundwater system and becomes surface-water runoff that eventually flows into West Branch Owego Creek. 


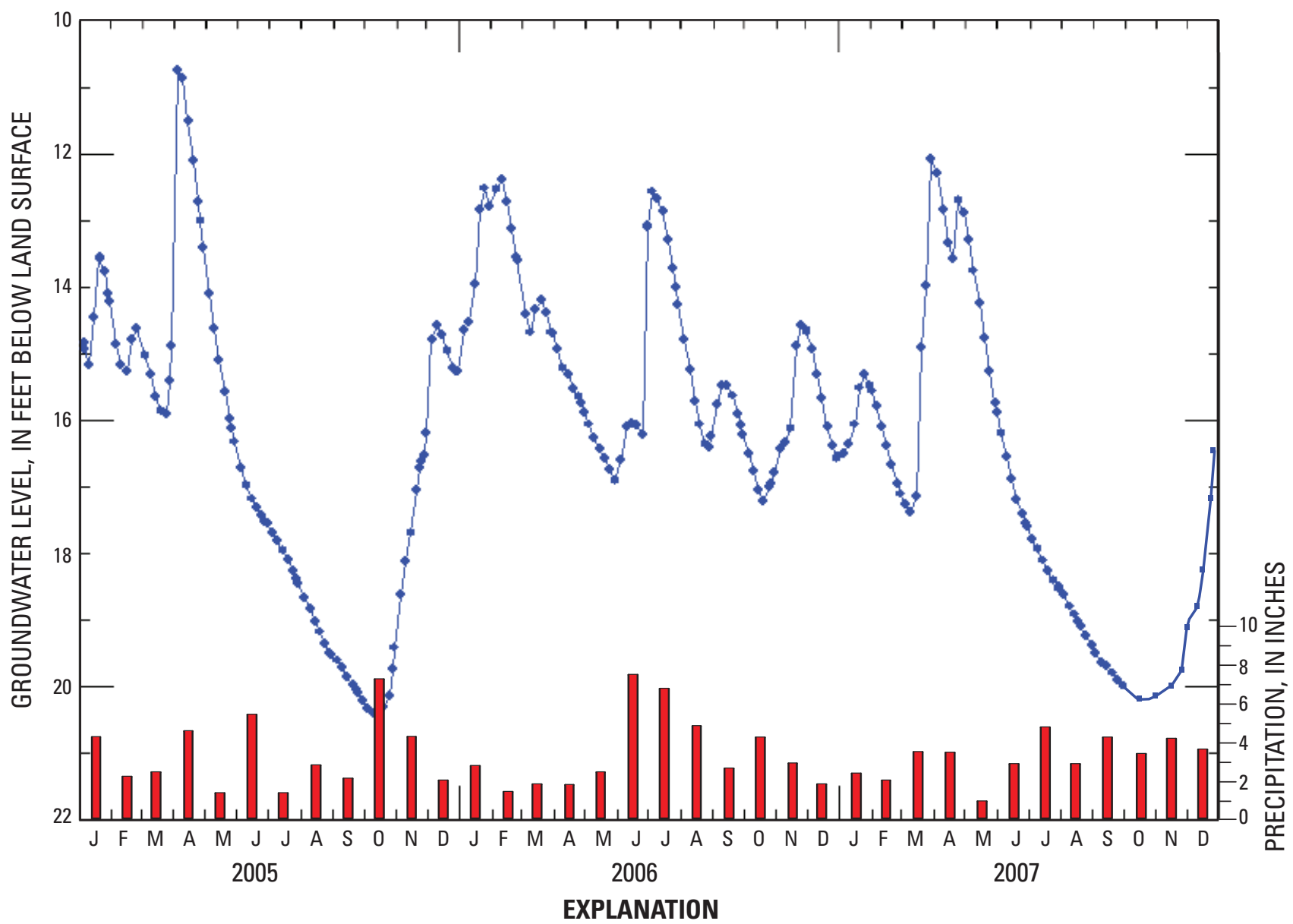

\footnotetext{
Water level, in feet below land surface, in U.S. Geological Survey Climate Response Network well TM1968

Monthly precipitation, in inches, at the Ithaca, NY, national weather station
}

Figure 15. Hydrograph of the water level below land surface from January 1, 2005, to December 31, 2007, in U.S. Geological Survey Climate Response Network well TM1968. (U.S. Geological Survey site Identification number 422323076190301) near Slaterville Springs, New York.

\section{Unchanneled Runoff and Groundwater Inflow from Adjacent Hillsides}

Additional sources of recharge to the unconfined aquifer are from adjacent hillsides to the valley. Runoff and groundwater inflow from these hillsides infiltrate into the unconfined aquifer along the edges of the valley (figs. 12 and 16). Average annual runoff from upland hillsides may be estimated by multiplying the average annual runoff rate for southern Tompkins County, about 20 in/yr (1.67 ft/yr, Kontis and others, 2004, plate 1), by the area of the unchanneled hillsides $2.36 \mathrm{mi}^{2}\left(6.58 \times 10^{7} \mathrm{ft}^{2}\right.$, fig. $12^{2}$ which yields a total recharge potential rate of $1.10 \times 10^{8} \mathrm{ft}^{3} / \mathrm{yr}$ or $3.56 \mathrm{ft}^{3} / \mathrm{s}$ (2.30 Mgal/d). Hillsides were excluded where the stream channel on the valley floor is adjacent to the hillside and intercepts runoff before it enters the aquifer. Unchanneled upland runoff typically accounts for 18 to 23 percent of the total recharge to unconfined valley-fill aquifers in central New York (Miller and others, 1998; Kontis and others, 2004; Miller and others, 2008).

\section{Seepage Losses from Upland Tributaries}

In the Appalachian Plateau of New York, tributaries that drain upland basins typically go dry seasonally where they enter larger valleys (Ku and others, 1975). Similarly, in this study area, losses from tributaries that flow across alluvial fans (fig. 5) adjacent to the main valley walls of upper Sixmile Creek valley and West Branch Owego Creek valley are likely a major source of recharge to the unconfined aquifer. The 


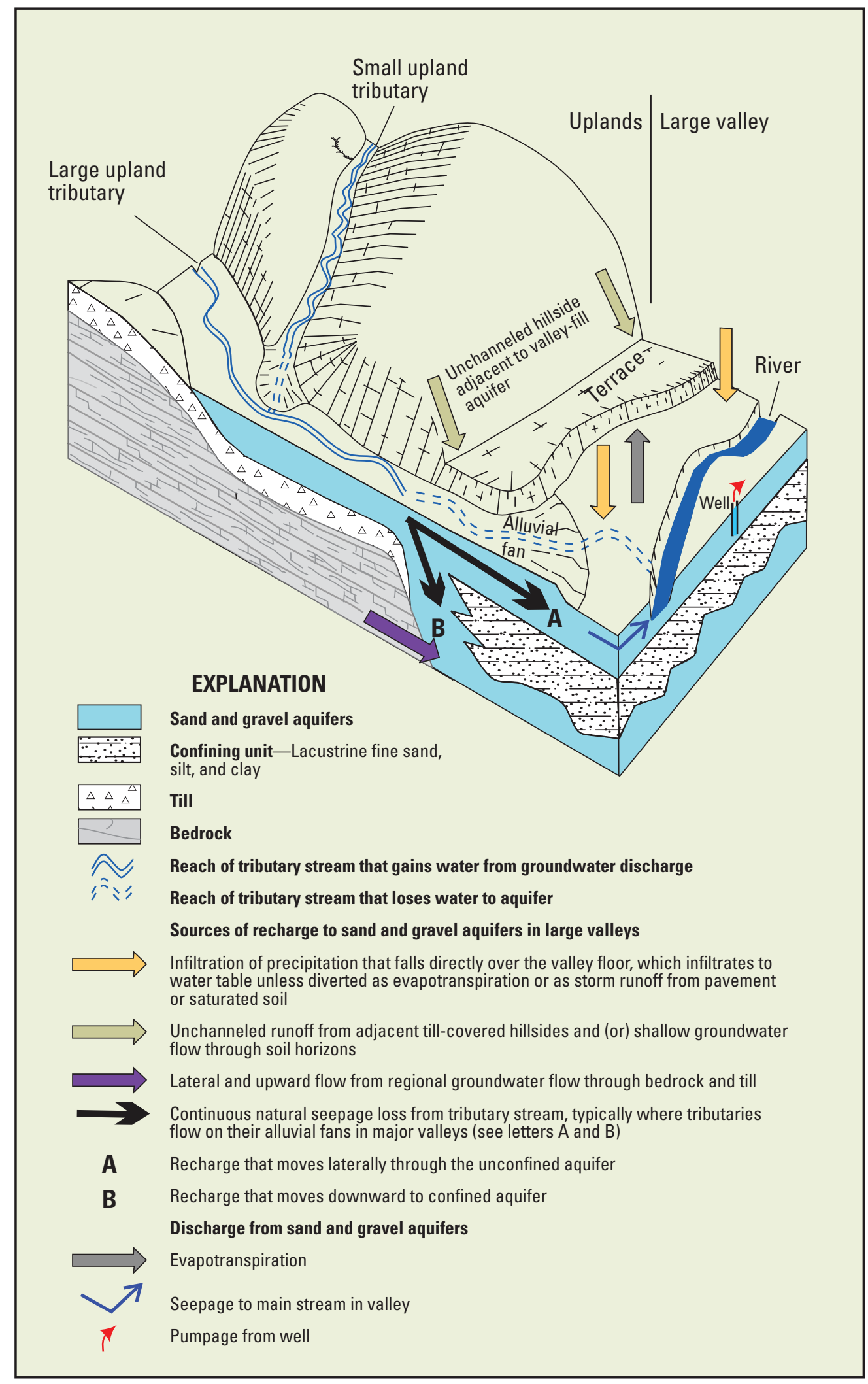

Figure 16. Sources of recharge to and discharge from valley-fill aquifers in New York. 
tributary streams in this study area have steep gradients near the valley sides and the water level in the tributary channel is higher than that of the adjacent groundwater table below; this condition favors seepage of substantial amounts of water from the tributaries into the valley-fill aquifer. In general, recharge from seepage losses from channeled upland runoff can occur through the banks as well as the bottom of the stream, and lateral hydraulic conductivity of streambank channel deposits can substantially exceed vertical hydraulic conductivity of the streambed. The rate of infiltration is a function of the hydraulic conductivity of the streambed and underlying materials, and the difference between the altitude of the stream stage and the altitude of the hydraulic head in the aquifer beneath the stream. Randall (1978) found that loss rates were small (less than $1 \mathrm{ft}^{3} / \mathrm{s}$ ) near the edges of the main valleys in the Upper Susquehanna River basin but were at least $1 \mathrm{ft}^{3} / \mathrm{s}$ per $1,000 \mathrm{ft}$ of channel several hundred feet downstream from the valley wall. Similar instances are likely to occur in the upper Sixmile Creek valley and West Branch Owego Creek valleys. Some stream reaches may show little or no loss because they are underlain by fine-grained deposits, rather than the typical alluvial sand and gravel, where losses could be much greater.

\section{Confined Aquifers}

The confined aquifers in the study area are overlain by relatively impermeable fine-grained sediments, which impede or slow infiltration of water from surface sources to confined aquifers. The sources of recharge to the confined aquifers are uncertain. Likely potential sources of recharge to the confined aquifers in the study area include (1) the sides of the valley, where confined aquifers may either extend up along the flank of the bedrock valley wall and become unconfined where they crop out at land surface or be overlain and in contact with surficial coarse-grained deltaic and fluvial sediments that constitute an avenue through which direct precipitation and seepage losses from tributary streams can reach the buried aquifers (fig. 16); or (2) slow seepage from adjacent finegrained sediment and bedrock where the buried aquifers are isolated by the confining units. Another potential source of recharge is from release of storage from the confining units due to pumping, but this is probably small in this study as there are no large pumping wells. Where the confined aquifers crop out at or near land surface along the sides of the valley, losing tributaries can provide direct recharge to the aquifer in these places. However, the main trunk stream, Sixmile Creek, is not in direct hydraulic contact with the confined aquifers (except in the western part of the study area); therefore, there is little interaction between the confined aquifers and Sixmile Creek. Where the confined aquifers are mostly isolated and completely surrounded by confining units, little or no surface water can recharge the aquifers. Isolated confined aquifers receive the least amount of recharge of all the aquifer types and hence have limited water availability.

\section{Groundwater Discharge}

Groundwater leaves the aquifers by discharging to surface-water bodies (wetlands, ponds, springs, and streams) and to pumped wells. Groundwater discharge supplements flow in streams during runoff and may comprise most of the streamflow during non-runoff periods.

In the West Branch Owego Creek valley, most groundwater in the unconfined aquifer flows eastward from the Valley Heads Moraine and discharges to wetlands and West Branch Owego Creek in the central part of the valley, and some groundwater discharges as underflow through the aquifer beyond the east end of the study area. Groundwater seeps into surface-water bodies where the water table intersects the stream channel or wetland. Most groundwater in the thin alluvial unconfined aquifer in upper Sixmile Creek valley discharges to Sixmile Creek along most of its course through the valley.

A large volume of groundwater was observed to discharge from the sand and gravel deposits on the back side of the Valley Heads Moraine into Sixmile Creek in the reach where the "Barille channel erosion control project" (fig. 12) was conducted in 2005 near Slaterville Springs, NY (Albert Morgan, U.S. Geological Survey, oral commun., 2007). Morgan estimated that 2 to $3 \mathrm{ft}^{3} / \mathrm{s}$ of groundwater were discharging to a 3,000 ft-long reach of Sixmile Creek in this area. Most water appeared to discharge from the surficial alluvial and kame moraine sand and gravel deposits (unconfined aquifer, figs. 5 and 7) that overlie a clay till (confining unit) that is exposed in the bottom of the streambed, but during excavation work in the channel, some seepage also appeared to come from below the clay till, suggesting that some groundwater was discharging from the confined aquifer below the clay till confining bed into the channel.

In upper Sixmile Creek valley, most groundwater (except that withdrawn by pumped wells) in the confined aquifers eventually discharges to streams and springs in the western part of the study area and to withdrawal wells. Upstream from the streamgage at Brooktondale, NY, in the west part of upper Sixmile Creek valley (figs. 5 and 11A), Sixmile Creek and another tributary to the north of the Sixmile Creek have incised deep ravines in the valley-fill deposits. The ravine cut by Sixmile Creek has eroded through all the unconsolidated deposits and has incised a 10- to 30 -ft gorge into the bedrock. The ravine cut by the unnamed tributary becomes increasingly deeper from north to south and penetrates to the top of the bedrock just before joining Sixmile Creek at Brooktondale. Because Sixmile Creek fully penetrates, and the unnamed tributary nearly fully penetrates the valley-fill deposits in this area, most groundwater in the valley-fill aquifers discharges into the streams. Therefore, the USGS streamgage, located at the lip of the exposed hanging valley at Brooktondale, NY (04233286), is a favorable site to measure the amount of groundwater discharge as well as runoff that flows from the basin. The base-flow portion of flow measured at the streamgage (groundwater that discharges into the channel) 
and its volume can be determined by using a hydrographseparation analysis routine that is discussed in the Sixmile Creek section of the report.

\section{Seepage to Streams}

Streams draining the unconfined aquifer are sustained entirely by groundwater discharge during base-flow periods. Streamflow in the headwaters ceases seasonally when the water table falls below the bottom of the stream channel. Rates of groundwater discharge to streams and recharge through infiltration from streams are, in part, a function of the difference in hydraulic head between the aquifer and stream, both of which can vary seasonally.

\section{Tributaries}

Although most tributary streams in the upper Sixmile Creek and West Branch Owego Creek valleys typically lose water where they flow over alluvial fans as they enter the main valleys, and the main trunk streams gain water from groundwater that discharges to the streams. In some parts of upper Sixmile Creek valley, some tributaries gain water from groundwater that discharges from the aquifer, such as in the Valley Heads Moraine area and in an unnamed tributary near Landon Road. This unnamed tributary begins north of Landon Road and incises into the valley-fill deposits as it flows southward and enters Sixmile Creek $200 \mathrm{ft}$ upstream from the streamgage at Brooktondale, NY (fig. 11A). This tributary was observed to have fairly constant flow and water temperature, both of which are typical characteristics of streams that receive groundwater discharge.

On July 16, 2007, a volumetric discharge measurement was made where the unnamed tributary empties into Sixmile Creek through a culvert. The measurement was made by recording the time it took the stream to fill a 50-gallon drum (figs. 11 A and 17). The measured discharge was $150 \mathrm{gal} / \mathrm{min}\left(0.33 \mathrm{ft}^{3} / \mathrm{s}\right)$, while the discharge in Sixmile Creek at the streamgage at Brooktondale was 5,390 gal $/ \mathrm{min}\left(12 \mathrm{ft}^{3} / \mathrm{s}\right)$. The unitized flow (discharge in cubic feet per second divided by drainage area in square miles, of the tributary stream was $1.87\left(\mathrm{ft}^{3} / \mathrm{s}\right) / \mathrm{mi}^{2}$ or 4.7 times more than that of Sixmile Creek at the Brooktondale, NY, streamgage, which was $0.4\left(\mathrm{ft}^{3} / \mathrm{s}\right) / \mathrm{mi}^{2}$. The much larger volume of flow per unit area in the tributary stream indicates that the tributary is receiving a greater amount of groundwater discharge per unit area in comparison to Sixmile Creek.

\section{Sixmile Creek}

Under natural conditions, the principal stream in each major valley (in this case, West Branch Owego Creek and Sixmile Creek) normally gains water continually from stratified-drift deposits, although some reaches may lose flow, especially during dry periods. Streams that normally gain flow can become local sources of recharge during periods of rising stage when the stream level becomes higher than the altitude of the water table; recharge by this mechanism is derived from temporary bank storage because much of the recharged water returns to the stream as the stream level drops.

A real-time, continuous streamgage (streamgage number 04233286, $27.0 \mathrm{mi}^{2}$ drainage area) was installed in November 2002 on Sixmile Creek at Brooktondale (figs. 3 and 11A) and is maintained by the USGS New York Water Science Center, Ithaca Program Office. Stage and discharge data have been collected for over 5 years, and the streamgage is still operating at the time of the publication of this report.

The Brooktondale streamgage is situated where Sixmile Creek flows on a bedrock channel and where the stream has incised a shallow gorge into shale. The streamgage is about

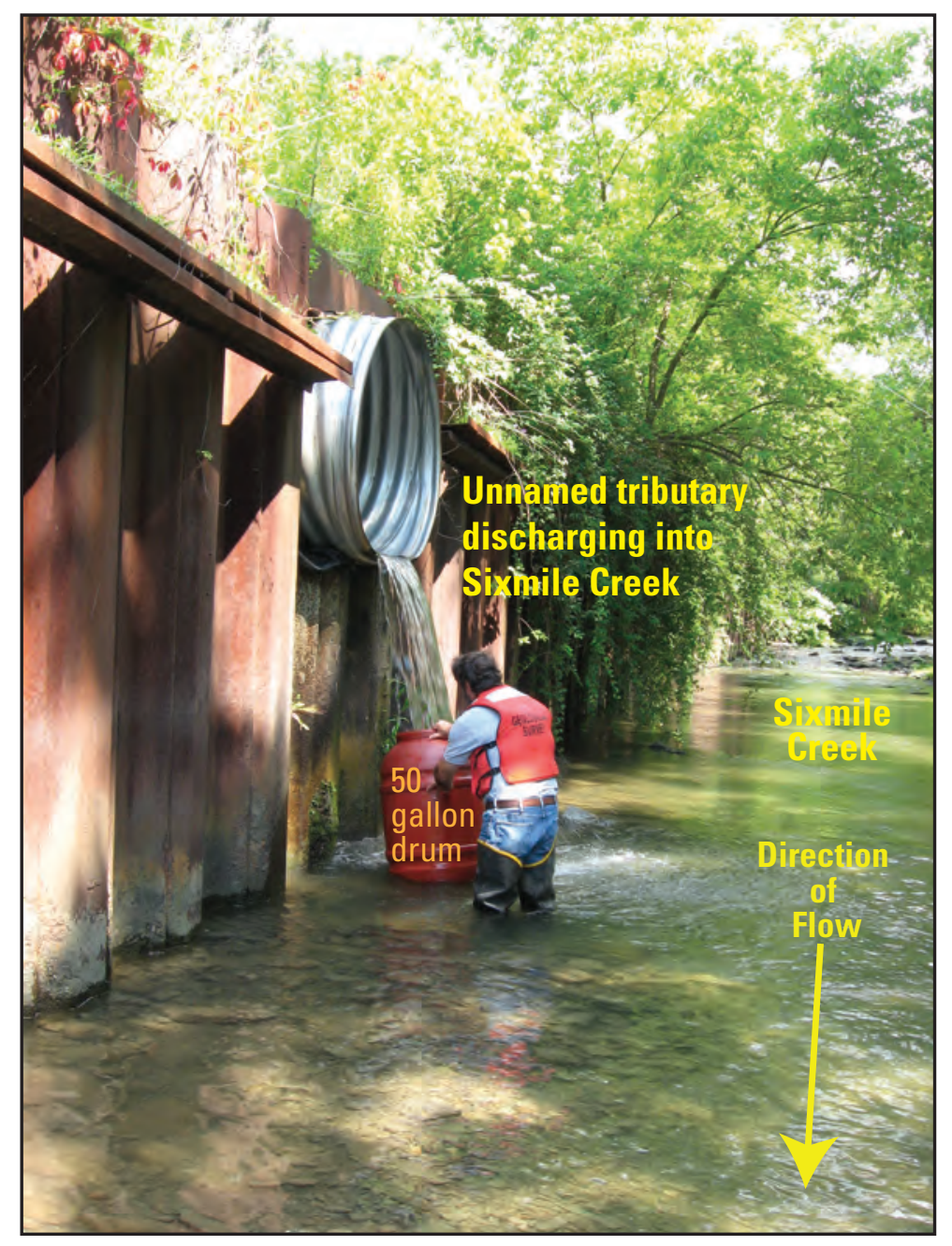

Figure 17. Volumetric measurement of a tributary entering 200 feet upstream of Sixmile Creek at Brooktondale, NY, streamgage on July 16, 2007. Location of photograph is shown in figure $11 \mathrm{~A}$. 
$50 \mathrm{ft}$ above the last of a series of waterfalls that forms the lip of the upper Sixmile Creek hanging valley. Graphs depicting the stream discharge record for the period from November 14, 2002, to September 30, 2006, are shown in figure 18.

Peak discharge for the period of record was $4,100 \mathrm{ft}^{3} / \mathrm{s}$ on April 2, 2005, (fig. 18C), and minimum discharge was $3.3 \mathrm{ft}^{3} / \mathrm{s}$ on October 1, 2, 3, 4, and 6, 2005 (fig. 18D); data are published in the New York Annual Water-Data Report 2006 (U.S. Geological Survey, 2009). For water years (October 1 through September 30) 2003-06, the mean annual discharge was $58.8 \mathrm{ft}^{3} / \mathrm{s}$, mean annual runoff was $29.57 \mathrm{in}$., and the flow per unit area was $2.18\left(\mathrm{ft}^{3} / \mathrm{s}\right) / \mathrm{mi}^{2}$; data are published in the New York Annual Water-Data Report 2006 (U.S. Geological Survey, 2009). The streamgage measures streamflow (fig. 18), which includes both the storm runoff and base flow that drains the upper Sixmile Creek basin. A stream is considered to be under base-flow conditions when little or no precipitation or snowmelt has occurred in the drainage area for at least 3 days or if the streamflow hydrograph suggests that discharge is steady or slowly declining. Most streamflow under these conditions is supplied by groundwater that has discharged to the stream.

The base-flow and runoff components (fig. 19) of total streamflow to Sixmile Creek at Brooktondale (upper Sixmile Creek basin) and to Sixmile Creek at Bethel Grove (lower Sixmile Creek basin) (fig. 3) were calculated using a hydrograph-separation computer program HYSEP (Sloto and Crouse, 1996) that utilized continuous discharge data for 2003-07. HYSEP calculates base flow as a percentage of total mean annual flow. The Sixmile Creek streamgages at Brooktondale and Bethel Grove meet the recommended condition for use of HYSEP in that they are not regulated by dams or flood-control reservoirs upstream from the streamgaging sites, which would cause an apparent decrease in stormflow and an apparent increase in base flow after a storm. However, streamflow records at these streamgages span a relatively short period (5 years), so these estimates are less representative of long-term conditions than streamgages with at least 30 years of record. If these 5 years are extremes, either low or high, then the estimated discharges may not represent long-term average runoff and base-flow values.

Results of the hydrograph-separation analyses for 2003-07 indicate that base flow constitutes 64 and 56 percent of total annual discharge at Sixmile Creek at Brooktondale, NY, and Sixmile Creek at Bethel Grove, NY, respectively (fig. 19). These results indicate that the flow past Brooktondale has a higher component that is derived from base flow (groundwater discharge) than at Bethel Grove. This result suggests that there is more groundwater discharge from aquifer units in upper Sixmile Creek valley than in lower Sixmile Creek valley. The greater percentage that is base flow in upper Sixmile Creek basin relative to that in lower Sixmile Creek basin is likely due to one or both of the following:

1. At Brooktondale, NY, the stream has eroded and fully penetrated the valley-fill deposits including the aquifer units, which results in little or no groundwater under- flow past the streamgage. At the Bethel Grove, NY, streamgage, however, the stream has only partly penetrated the valley-fill deposits. Therefore, a significant portion of the groundwater probably flows beneath the streamgage as underflow and does not enter the stream until further down the valley where the channel has fully penetrated the valley-fill deposits and flows on bedrock.

2. The volume of surficial sand and gravel is greater in the upper Sixmile Creek basin than in the lower Sixmile Creek basin. Surficial sand and gravel deposits reduce rapid runoff by storing precipitation for gradual release. In valleys with relatively large amounts of sand and gravel, there is proportionally more infiltration of precipitation and greater storage capacity; therefore, more groundwater discharges to streams than in valleys that contain mostly till and lacustrine deposits, which have poor infiltration capacity and rapid runoff.

\section{Pumped Withdrawals and Water Availability}

No large municipal or industrial pumped wells are in the study area. Most groundwater withdrawals are from homeowner wells with open-ended, 6-in.-diameter casings, but a smaller amount of withdrawals are also made from shallow-dug wells and cisterns that collect groundwater that discharges from springs (especially in the Brooktondale area). Because all homes have septic systems, most groundwater that is withdrawn by homeowners returns to the groundwater system in the unconfined aquifer or in the surficial confining unit, where present. The valley-fill aquifer is the source of water for about 200 households, several apartment complexes, two mobile home parks, a school, and several farms and small businesses.

About 750 people live in the study area, and almost all rely on groundwater from the valley-fill aquifer system. In addition, water is used by nonpermanent residents, such as students and staff at the Caroline Elementary school (built in 1959 with an addition added in 1967), and some water is used for nonhuman consumption at farms and commercial facilities. The estimated total groundwater use for human consumption is estimated to be about 74,200 $\mathrm{gal} / \mathrm{d}$ or $0.11 \mathrm{ft}^{3} / \mathrm{s}$ based on an average water use of $75 \mathrm{gal} / \mathrm{d}$ per person for self-supplied water systems in New York (Hutson and others, 2000, table 6) and $40 \mathrm{gal} / \mathrm{d}$ per person for about 450 nonpermanent residents (mostly elementary school students and staff). Unknown quantities of water are also drawn from wells in the valleyfill aquifer, including (1) several dairy and horse farms (the number of animals is unknown), (2) an unknown number of flowing artesian wells that continually discharge water from the aquifer, even when the water is unused, and (3) several small commercial facilities.

The unconfined aquifer in the study area has a greater potential for groundwater development than the confined aquifers. The unconfined aquifer in the eastern part of the study area receives more recharge than the confined aquifers 

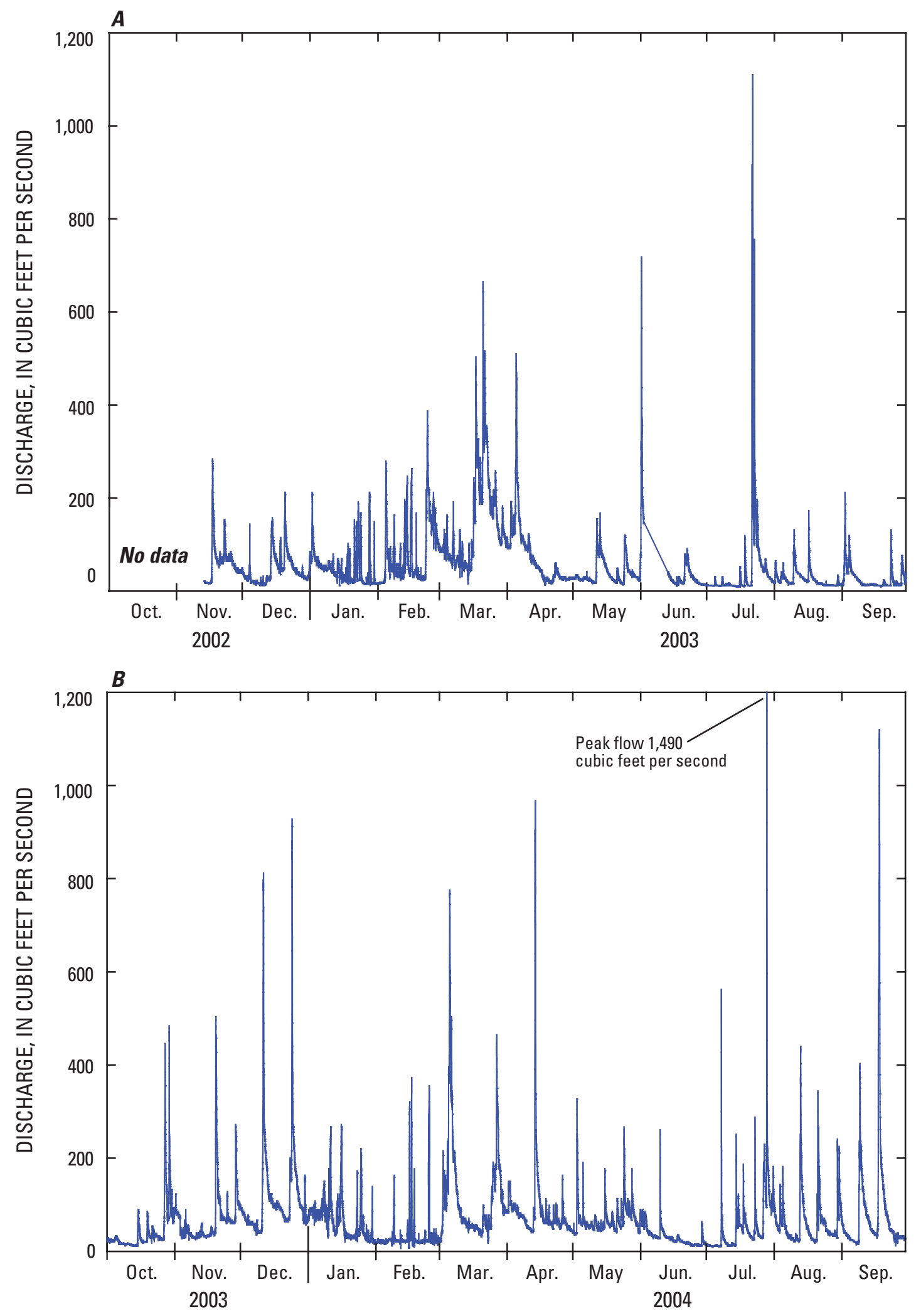

Figure 18. Discharge for Sixmile Creek at Brooktondale, New York (U.S. Geological Survey streamgage Identification number 04233286) for (A) water year 2003, (B) water year 2004, (C) water year 2005, and (D) water year 2006. 

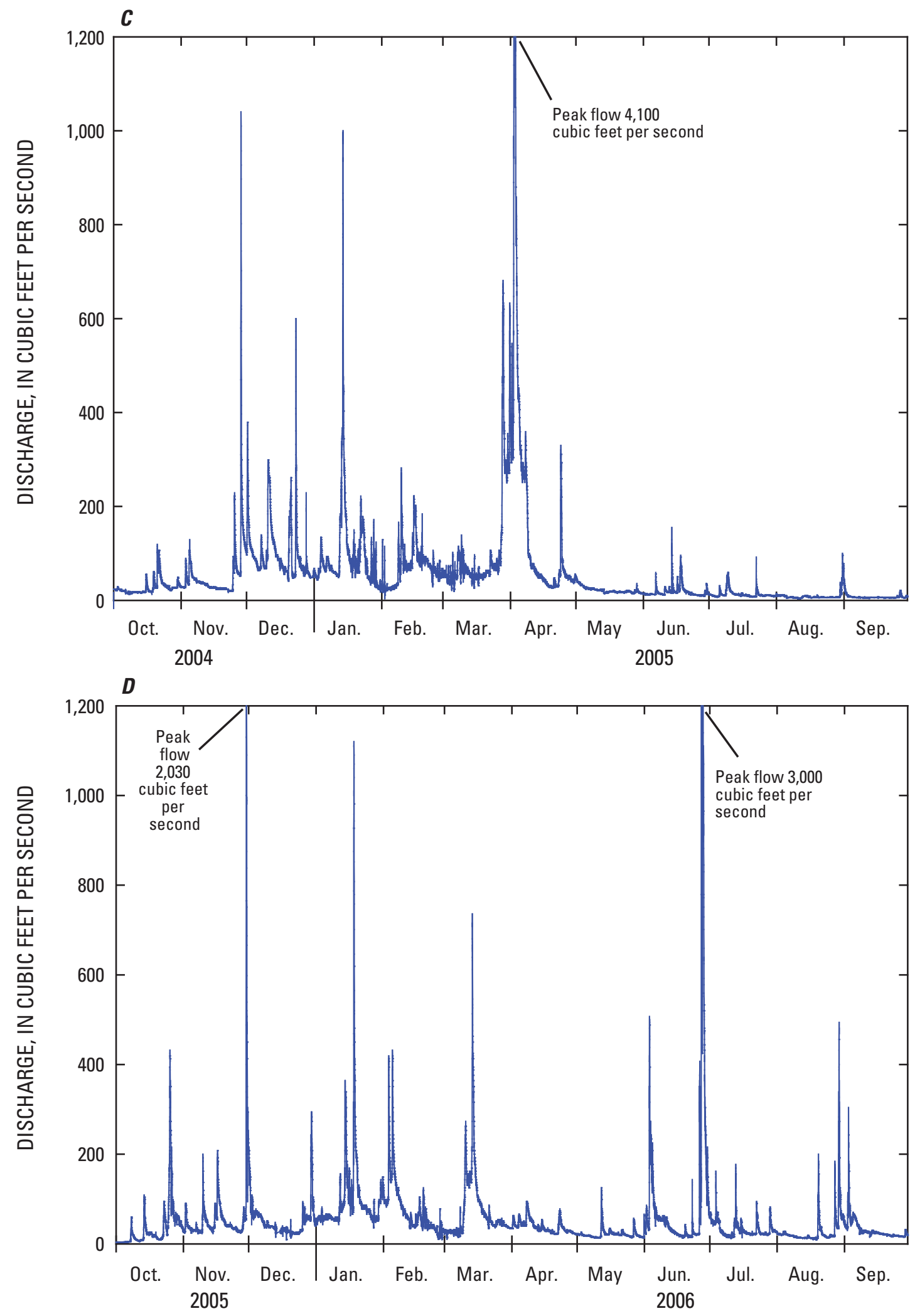

Figure 18. Discharge for Sixmile Creek at Brooktondale, New York (U.S. Geological Survey streamgage Identification number 04233286) for (A) water year 2003, (B) water year 2004, (C) water year 2005, and (D) water year 2006. 

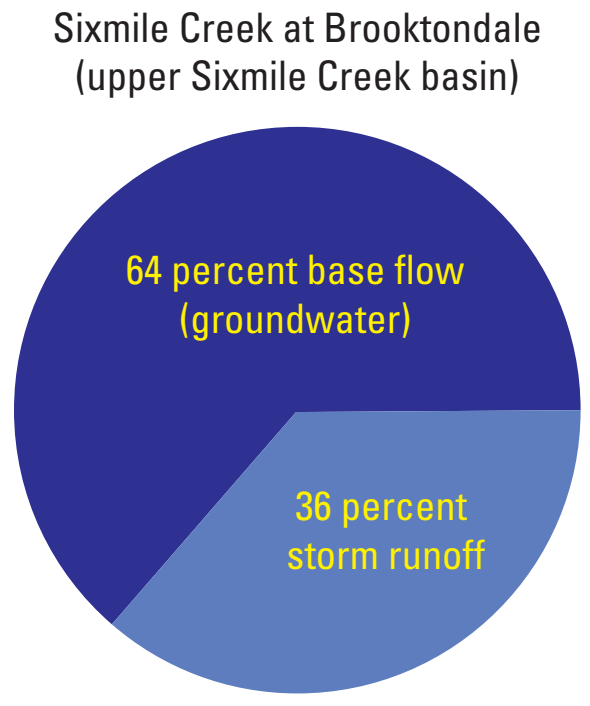

Sixmile Creek at Bethel Grove (lower Sixmile Creek basin)

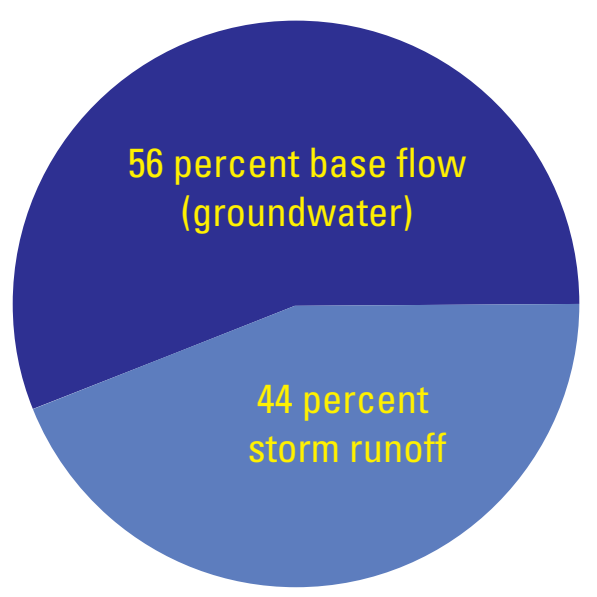

Figure 19. Results of hydrograph-separation analyses for Sixmile Creek at Brooktondale, New York (upper Sixmile Creek basin), and Sixmile Creek at Bethel Grove, New York (lower Sixmile Creek basin), streamgages for the period 2003-07. Locations of streamgages are shown in figure 3.

because it generally has greater permeability than the confined aquifers and readily receives recharge from several sources, including direct precipitation on land surface, losing tributary streams, and seepage of runoff from adjacent unchanneled hillsides. Therefore, the relatively large amounts of water that recharge the unconfined aquifer generally result in greater potential for large sustainable yields to pumping wells. Where the valley-fill aquifer is confined, the permeability of the aquifer sediments tend to be more variable (sand and gravel zones mixed with predominantly sand zones) and the amount of recharge is less. Therefore, the amount of water available to wells may be somewhat less in the confined aquifers than in the unconfined aquifer.

Table 1 provides the range, mean, and median of well yields and well depths for the unconfined, confined, and bedrock aquifer units in the study area. The data in the table were reported by water-well drillers except for the test wells drilled for this study, which were recorded by USGS personnel who logged the well. The well data were entered into the USGS National Water Information System (NWIS). In general, the reported yields of open-ended wells were somewhat greater for the unconfined sand and gravel aquifer (mean of $18 \mathrm{gal} / \mathrm{min}$ and median of $15 \mathrm{gal} / \mathrm{min}$ ) than that for the confined aquifers (mean of $15 \mathrm{gal} / \mathrm{min}$ and median of $12 \mathrm{gal} / \mathrm{min}$ ). Bedrock wells generally had lower yields (mean of $8 \mathrm{gal} / \mathrm{min}$ and median of $6 \mathrm{gal} / \mathrm{min}$ ) than the valley-fill aquifers. Yields from wells installed in the sand and gravel aquifers would be greater if they were constructed using well screens and properly developed.

\section{Breaching of the Confining Unit at Slaterville Springs}

In early July 1993, test boring and excavation work for an abutment at Buffalo Road Bridge in Slaterville Springs (fig. 13) breached the upper confining unit, which resulted in water from the confined aquifer discharging into the channel of Sixmile Creek. The breach of the confining unit released enough hydraulic pressure in the aquifer to cause several wells in the hamlet, which normally are under flowing artesian conditions, to stop flowing; this included the flowing artesian well at the Town Hall, 1,400 ft west of the bridge. As a result, water had to be supplied to several homes and businesses in the area. Bentonite pellets and a grout curtain were installed in the channel, which stopped the leak. A test well (TM 999, fig. 6) was installed on the streambank near the north end of the bridge on Aug. 8, 1993, to monitor water levels in the confined aquifer. The test well was screened from 35.5 to $41 \mathrm{ft}$. Results of the test drilling indicated that the top of the confined aquifer was $35 \mathrm{ft}$ below land surface from the top of the streambank, or about $22 \mathrm{ft}$ below the streambed. Water levels were measured by personnel from the Tompkins County Public Works Department and the Town of Caroline Highway Department from August 8, 1993, to November 11, 1994. Although water levels in the monitoring well were not measured until after the grout curtain was installed, the waterlevel measurements indicated that the head dropped more than $10 \mathrm{ft}$ in the aquifer after the confining unit was breached (fig. 20). Then, after the grout was installed, the water level 
rose for at least a month until it reached equilibrium (fig. 20), but it is unknown whether this equilibrium level represents static water level before the breach occurred because there were no water-level measurements made before the breach, and it took about a week after the monitoring well was installed (about 6 weeks since the breach had occurred) for the water level to recover to near static level (fig. 20) in the vicinity of the bridge.

This incident demonstrated that the hydraulic heads in the confined aquifer system are sensitive to large stresses, such as the introduction of a large pumping well or breaching of the confining unit by excavation or stream channel erosion. In addition, an accumulation of small, continuous stresses may also affect local groundwater levels in the confined aquifers. These small stresses may include (1) improperly finished wells that lack a proper seal, which enable water to escape from the aquifer around the outside of the casing, (2) wells in low areas of the valley that tap the confined aquifer and are allowed to continuously flow and drain into ditches (analogous to a perpetually flowing leaky faucet), and (3) an increase in residential development throughout the valley that has resulted in an increased withdrawal from the confined aquifers as a source of water. If enough of these small stresses were to occur, the result may be to lower the head in the confined aquifer system enough so that the low areas in the valley will cease to be under artesian flowing conditions.

\section{Water Quality}

Water samples were collected to describe the chemical quality of groundwater and the base-flow component of surface water in the study area. For this study, nine groundwater samples were collected from wells finished in sand and gravel aquifers, and one from a well finished

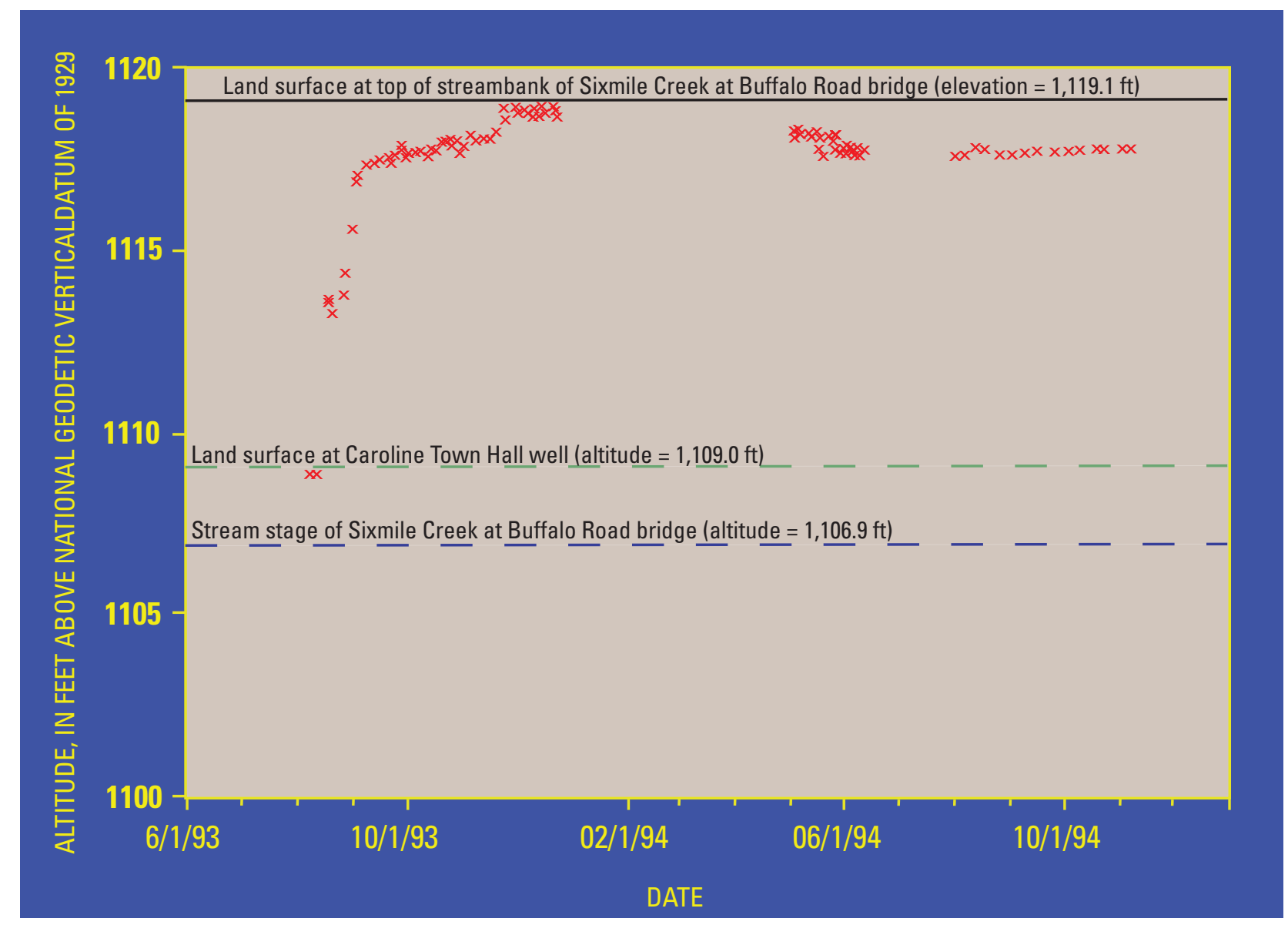

Figure 20. Hydrograph of groundwater levels in monitoring well TM 999 near bridge over Buffalo Road, from August 7, 1993, to November 7, 1994, Slaterville Springs, New York. Location of site is shown in figure 13. 
in bedrock. Ten surface-water samples were collected seasonally during base-flow conditions at the Sixmile Creek at Brooktondale streamgage (04233286) during the years 2003-05, and 13 samples were collected during base-flow conditions at several selected tributaries to Sixmile Creek and West Branch Owego Creek during the years 2004-05.

Where the valley-fill aquifer is unconfined in the study area, the surficial sediments are generally highly permeable and connected directly with the surface water; therefore, this part of the aquifer is vulnerable to immediate contamination from spills or improper disposal of liquids or soluble substances that could be leached into the aquifer. Conversely, in the part of the study area where the valley-fill aquifer is confined, a fine-grained sediment layer of low hydraulic conductivity restricts vertical flow between aquifer units.

\section{Surface Water}

Ten surface-water samples were collected by USGS personnel at roughly seasonal intervals during base-flow conditions at the Sixmile Creek at Brooktondale streamgage (04233286) during the years 2003-05 (table 2), and

13 samples were collected during the years 2004-05 from 4 tributaries in the study area (table 3). Samples were collected for analyses of nutrients, common ions, and inorganic constituents by the USGS National Water Quality Laboratory (NWQL) in Denver, Co. The location of surface-water sampling sites is shown in figure 21.

Although base flow is an approximation of the chemical quality of groundwater, the concentrations of some constituents can be altered in the stream through contact with air and stream biota. For example, increased temperatures in the spring and summer result in an increase in microbial activity and algal growth in the streams, which can change dissolved oxygen concentrations, utilize the nitrogen in the water, and potentially cause decreased nitrate concentrations through denitrification if denitrifying bacteria are present. Therefore, base-flow quality under non-snowmelt conditions in winter, when temperatures are low and microbial activity and algal growth are minimal, provides the best approximation of the average chemical quality of shallow groundwater within the drainage area.

Additional surface-water samples were collected during both base-flow and runoff periods from 2004 to 2006 in the Sixmile Creek basin by a citizen's volunteer group and analyzed for chemical, physical, and bacteriological indicators by the Community Science Institute (CSI), a nonprofit organization that operates a New York State Department of Health (NYSDOH) certified laboratory. The results of CSI chemical analyses can be found at http://www.communityscience.org/SixMile/sixmilecreek.html (accessed October 14, 2008).

\section{Physical Properties}

The $\mathrm{pH}$ of the USGS collected surface-water samples (tables 2 and 3) ranged from 7.3 to 8.0; all of the 23 samples were within the accepted Secondary Maximum Contaminant Level (SMCL) range of 6.5 to 8.5 (U.S. Environmental Protection Agency, 2006). Specific conductance of the samples ranged from 121 to 426 microsiemens per centimeter $(\mu \mathrm{S} / \mathrm{cm})$ and dissolved oxygen concentrations (tables 2 and 3 ) ranged from less than 5.2 to 15.1 milligrams per liter $(\mathrm{mg} / \mathrm{L})$.

Suspended sediment data were collected in Sixmile Creek at Brooktondale by the Tompkins County Soil and Water Conservation District to determine the load of sediment that is transported through this part of the basin, most of which ends up settling behind the silt dam above the Sixmile Creek reservoir in lower Sixmile Creek valley (fig. 3). This reservoir is the source of drinking water for the City of Ithaca, NY (fig. 3). Records of daily suspended sediment are available from the City of Ithaca Water Treatment Plant.

\section{Common Inorganic Constituents}

The major-ion composition of water from sampled streams and wells was evaluated using a Piper (trilinear) diagram (fig. 22). A Piper diagram (Piper, 1944) shows the relative contribution of major cations and anions, on a charge-equivalent basis, to the total ion content of the water. Percentage scales along the sides of the diagram indicate the relative concentration, in milliequivalents per liter, of each major ion. Cations are shown in the left triangle and anions are shown in the right triangle. The central diamond integrates the data.

Calcium dominates the cation composition and bicarbonate dominates the anion composition in most samples of base flow in the study area (fig. 22). In general, tributary samples were slightly more calciumbicarbonate rich than Sixmile Creek samples collected at Brooktondale and slightly less calcium-bicarbonate rich than groundwater samples (fig. 22). However, in general, water in all stream and groundwater samples was similar, except for groundwater samples from the two test wells at the Caroline Elementary School (TM 994 and TM1967), which suggests that the samples were collected in the streams during base-flow conditions and represent predominantly groundwater discharge.

The base-flow samples collected from the tributary to Sixmile Creek at Route 79 bridge at Slaterville Springs, which drains the back side of the Valley Heads Moraine, and from the tributary in the north part of the aquifer near Midline Road (fig. 21) have relatively high concentrations of calcium bicarbonate (tables 2 and 3 ) because most of the water is derived from discharge from carbonate-rich sand and gravel that comprises much of the Valley Heads drift in the valley. Base flow that is derived primarily from groundwater that discharges from upland till and shale, such as the sample collected at the tributary to Willow Creek at New York 


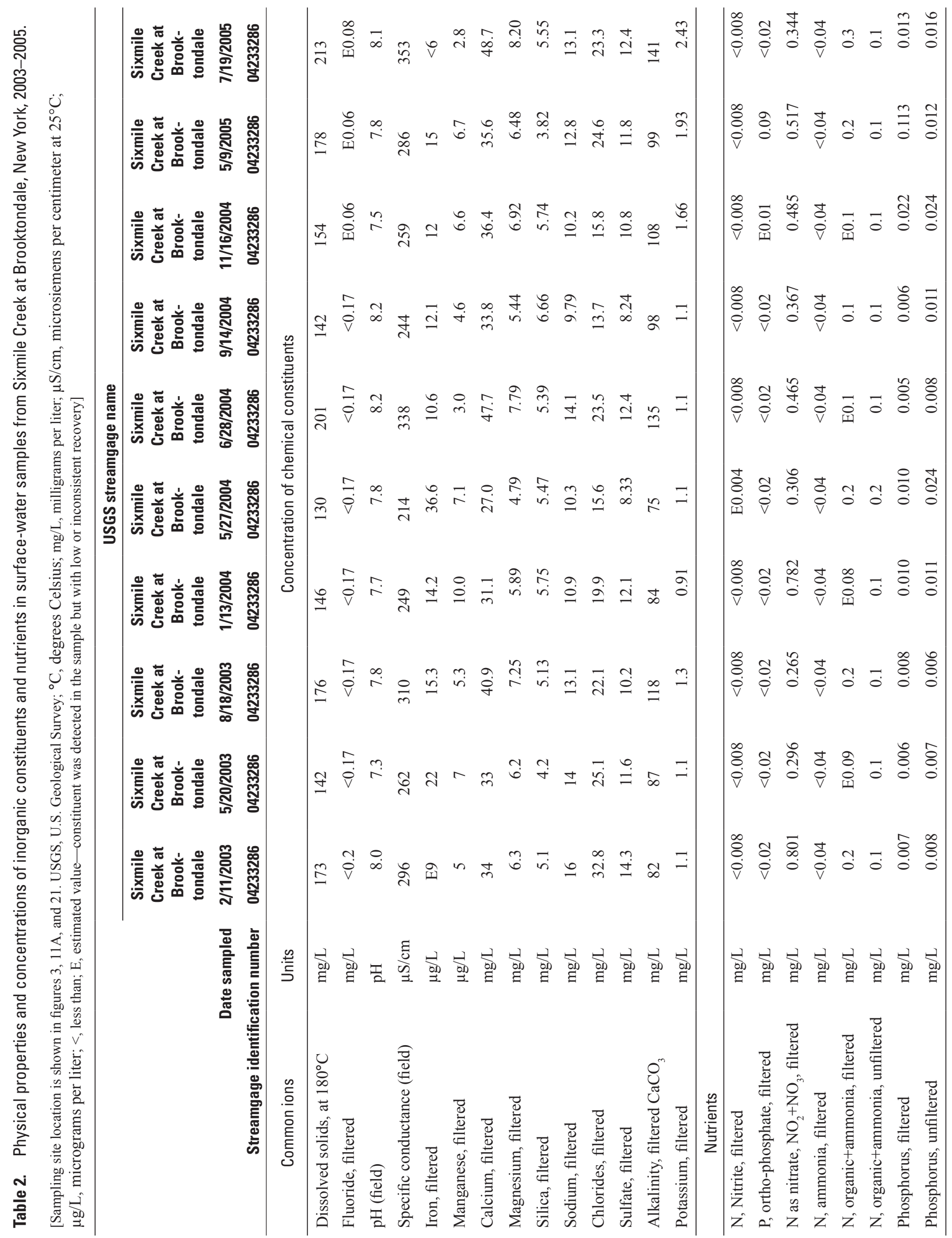




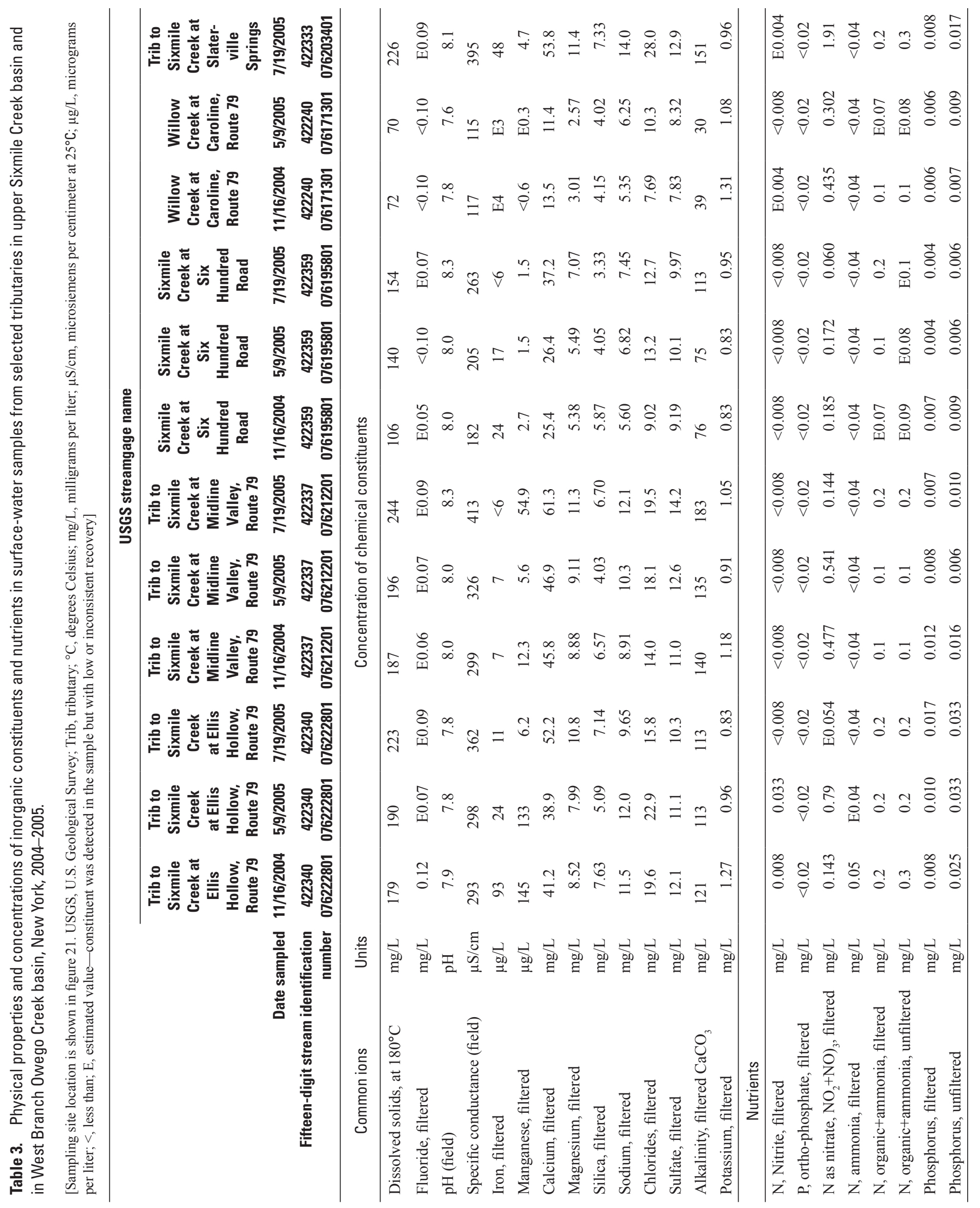




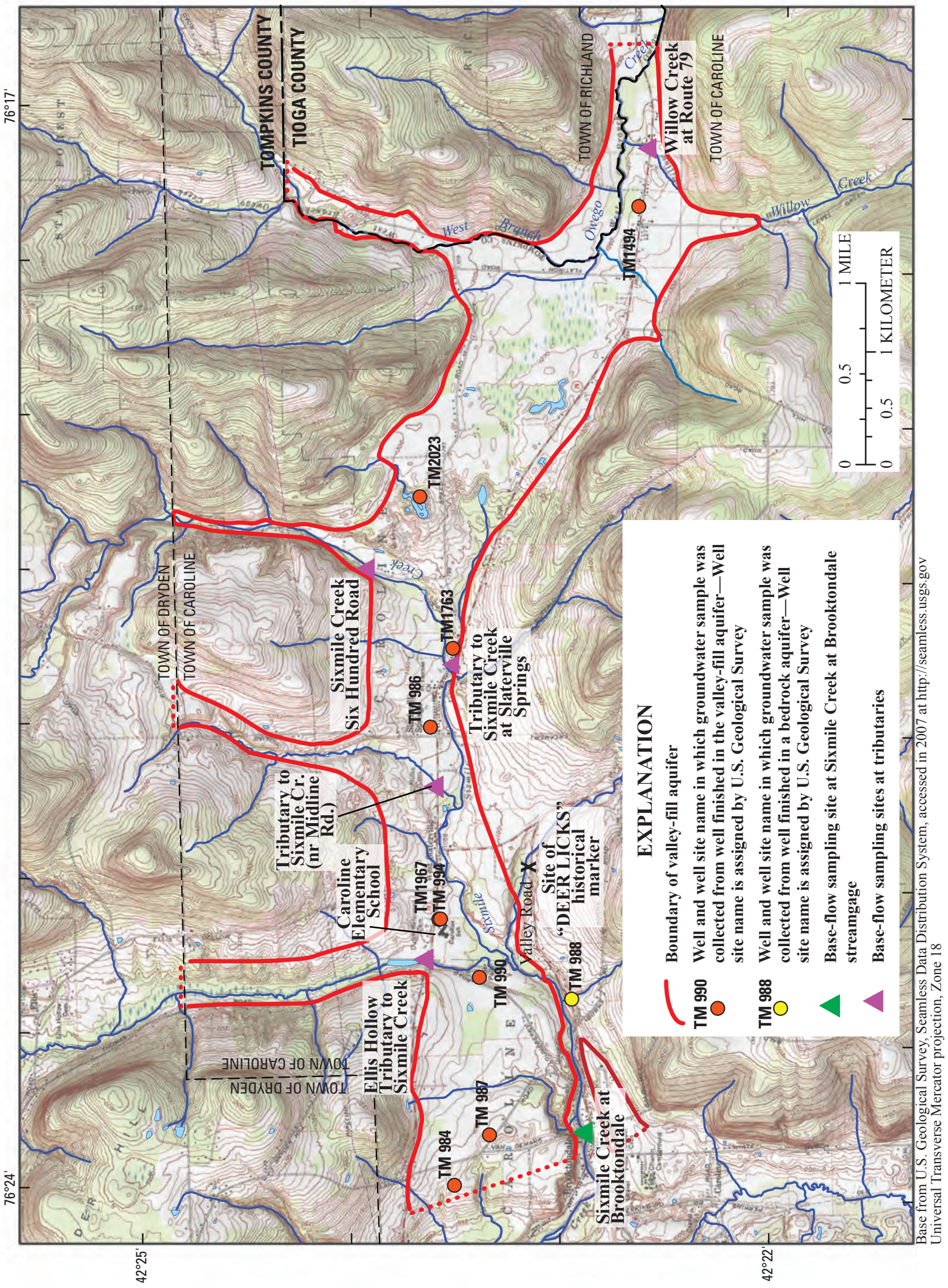

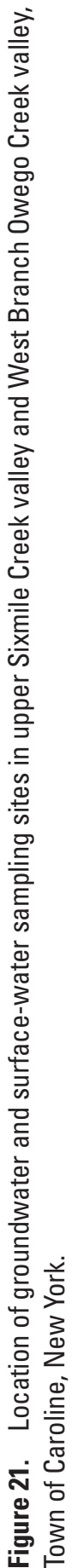




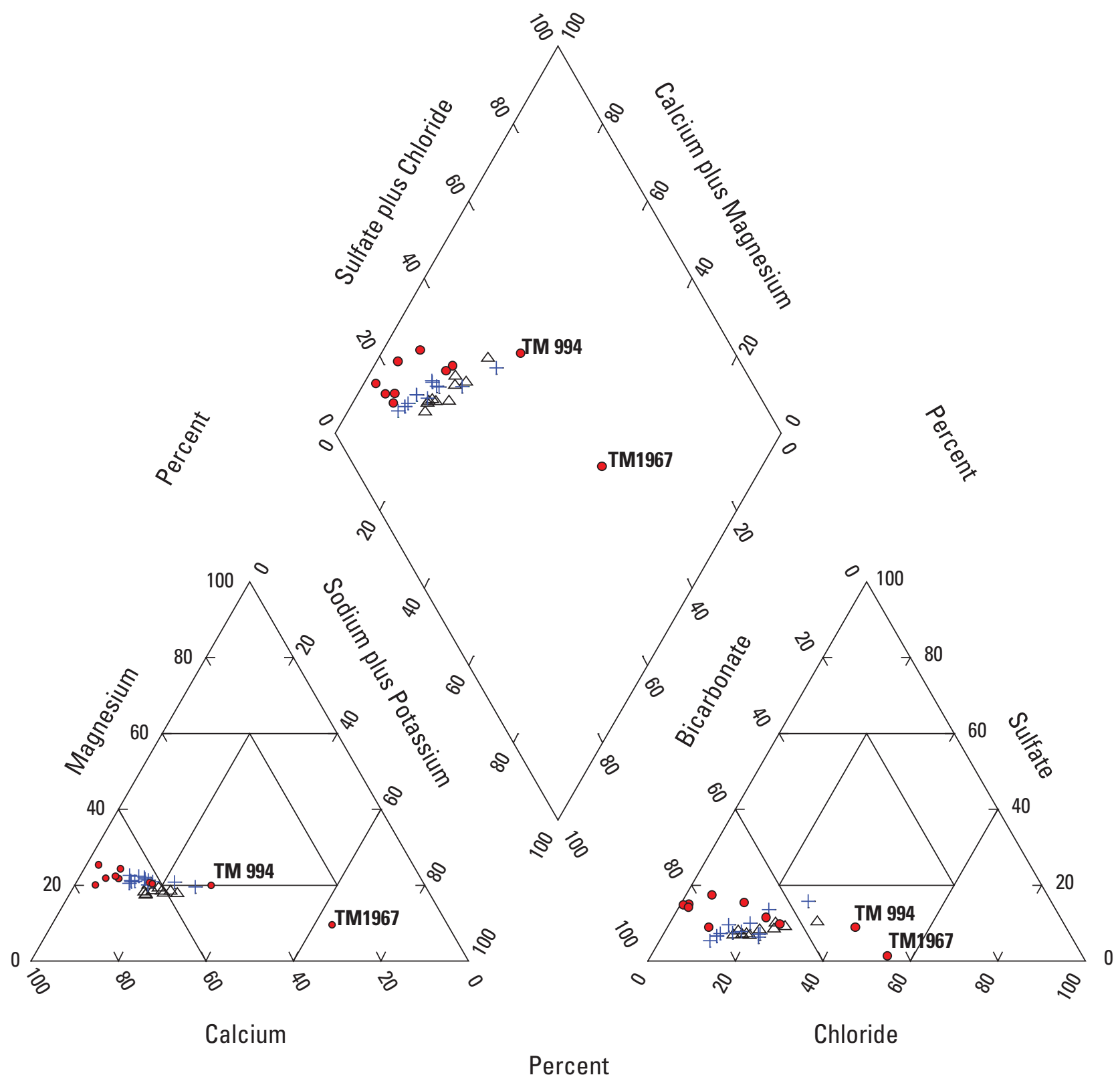

EXPLANATION

TM $994 \bigcirc$ Groundwater sample and well site name-Site name is assigned by the U.S. Geological Survey. Well record is in Appendix 1 at end of report

$\triangle$ Sixmile Creek at Brooktondale sample

+ Tributary sample

Figure 22. Variability in major ion composition of surface water and groundwater in the lower Sixmile Creek and West Branch Owego Creek valleys, Town of Caroline, New York. 
State Route 79 and Sixmile Creek at the abandoned bridge on Six Hundred Road (fig. 21), has lower concentrations of calcium bicarbonate because these deposits contain much less carbonate material than the sand and gravel deposits.

Concentrations of most constituents in Sixmile Creek at Brooktondale were similar for all 10 rounds of samples collected from 2003 to 2005 except for concentrations of calcium and magnesium, which were detected at greater concentrations during the summer round of samples (tables 2 and 3). The greater concentrations of calcium and magnesium in the summer samples likely reflect a difference in the source area that supplies the groundwater discharge to the streams. When evapotranspiration is minimal during winter and early spring, there is more young freshwater from precipitation that recharges the upper part of the stratified drift, which then discharges to the stream. Conversely, when evapotranspiration is greater during the summer, often exceeding the rate of precipitation, there is little recharge to the stratified drift. Therefore, the water that discharges locally into the streams consists of older water derived from deeper zones in the aquifer with longer flow paths and resident times that permit more mineralization.

Sodium and chloride concentrations are relatively low in all streams but increase somewhat downstream in Sixmile Creek between the sampling site at Six Hundred Road near Slaterville Springs and the sampling site at the Brooktondale streamgage (fig. 21). Some of the increase in sodium and chloride concentrations could be attributed to road salt, but most is probably natural discharge of brackish water originating from deep zones in bedrock that discharges upward; some of the brackish water enters the unconsolidated deposits in the valley, while some discharges to springs that eventually drain into Sixmile Creek. A spring, which originates on a hillside south of Valley Road and flows into one of the tributaries that drains to Sixmile Creek, was found to have a history of brackish water. This brackish spring is close to a historic highway marker (location shown in fig. 21) that attests to the origin of natural brackish water; the signage states "DEER LICKS - INDIANS AND EARLY SETTLERS HERE OBTAINED THEIR SALT" (fig. 23).

\section{Nutrients}

Base-flow samples collected during the years 2003-05 were analyzed for several nitrogen species; the predominant species in all samples was nitrate (tables 2 and 3). Nitrogen is vital to the growth of vegetation, but too much nitrogen in streams, commonly derived from fertilizers and sewage, can cause excessive plant and algal growth. When this organic matter decomposes it can clog waterways, which depletes the oxygen in the water column that is needed by other aquatic life. Excessive nitrate in drinking water is also a human health concern; as a result, the U.S. Environmental Protection Agency (USEPA) has established $10 \mathrm{mg} / \mathrm{L}$ (as N) as the maximum contaminant level (MCL) (U.S. Environmental Protection Agency, 2006). The concentration of nitrate was less than $1.0 \mathrm{mg} / \mathrm{L}$ in all base-flow samples except in the tributary to Sixmile Creek at Slaterville Springs, NY, on July 19, 2005, when it was detected at $1.91 \mathrm{mg} / \mathrm{L}$ and on May 5,2005 , the concentration was $1.97 \mathrm{mg} / \mathrm{L}$. During the summer, this tributary receives groundwater that discharges from the Valley Heads Moraine, which is overlain by large amounts of agriculture areas.

Concentrations of nitrate are lowest in the summer samples, which likely are the result of nitrogen uptake by vegetation and microbial activity in the streams. Higher nitrate concentrations in winter samples relative to summer samples can be attributed to seasonal decreases in plant growth and microbial activity in the streams during the winter, which allows nitrate to persist in the stream.

\section{Groundwater}

Groundwater samples were collected from 10 wells ( 8 finished in confined sand and gravel aquifers, 1 finished in an unconfined aquifer, and 1 finished in bedrock (fig. 21). Field measurements were made of $\mathrm{pH}$, specific conductance, and water temperature. Samples were collected for analyses of nutrients, common ions, and inorganic constituents by the USGS NWQL in Denver, Colo. Several samples were also collected for analyses for groundwater age dating by the USGS Chlorofluorocarbon Laboratory in Reston, Va.

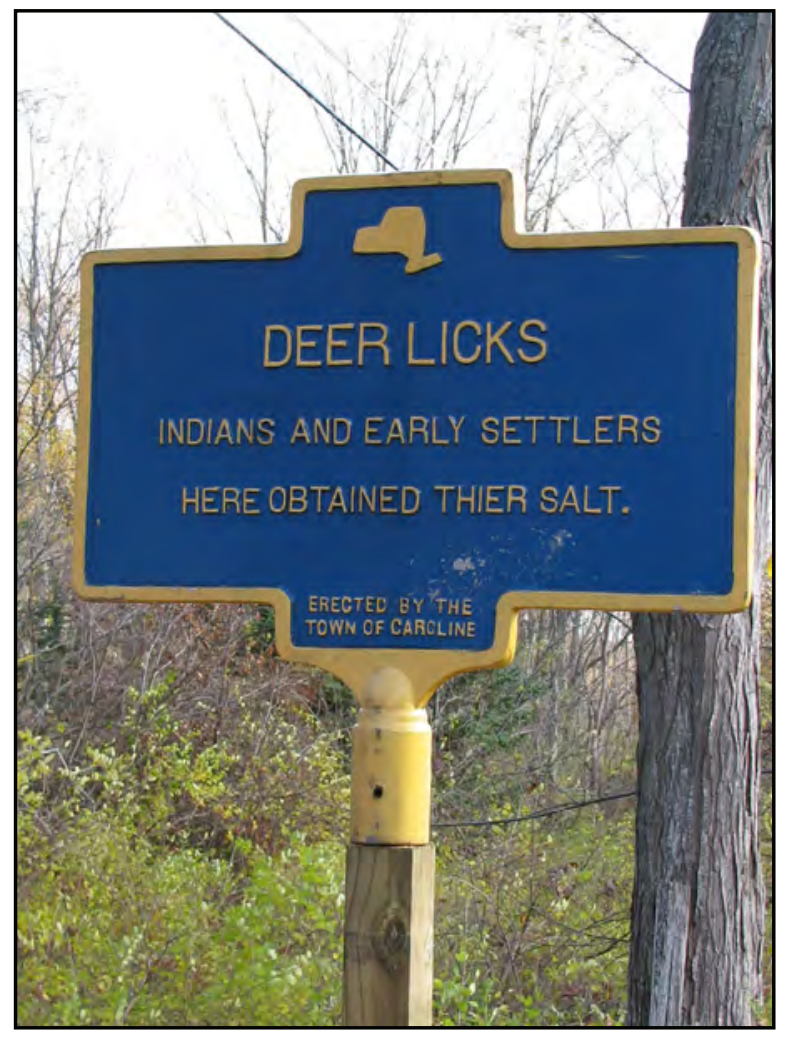

Figure 23. The Deer Licks historic highway marker along the side of Valley Road, Town of Caroline, New York. 


\section{Physical Properties}

The $\mathrm{pH}$ of the groundwater samples (table 4 ) ranged from 6.5 to 8.0 , specific conductance of the samples ranged from 216 to $807 \mu \mathrm{S} / \mathrm{cm}$ and dissolved oxygen concentrations (tables 2 and 3) ranged from less than 0.19 to $6.0 \mathrm{mg} / \mathrm{L}$. Well TM1494, which was the only well that was finished in the unconfined aquifer, produced water with the highest dissolvedoxygen concentration.

\section{Common Inorganic Constituents}

Results of the groundwater sample analyses indicate that the water is generally of good quality, potable, and predominantly a calcium-bicarbonate type, except for groundwater samples from wells TM 994 and TM1967 where the composition becomes more dominated by sodium and chloride than the other groundwater samples (fig. 22). The cation that was typically detected in the highest concentration was calcium, ranging from 25.8 to $80.1 \mathrm{mg} / \mathrm{L}$ (table 4). Sodium values ranged from 2.61 to $106 \mathrm{mg} / \mathrm{L}$, and two samples (TM 994 and TM1967) exceeded the USEPA Drinking Water Advisory for sodium, which recommends that sodium concentrations in drinking water do not exceed 30 to $60 \mathrm{mg} / \mathrm{L}$ on the basis of taste (U.S. Environmental Protection Agency, 2006). Silica values ranged from 5.76 to $13.7 \mathrm{mg} / \mathrm{L}$. The SMCL for iron (300 micrograms per liter, $\mu \mathrm{g} / \mathrm{L}$ ) was exceeded in one sample, while the SMCL for manganese $(50 \mu \mathrm{g} / \mathrm{L})$ was exceeded in six samples (table 4).

Variations in sodium concentrations were probably due to either enrichment through road de-icing salts or from brackish water in bedrock that locally discharges to the valley fill. The brackish water that discharges from the spring along Valley Road presumably discharges to the valley-fill aquifers where bedrock is in contact with the aquifer beneath the valley and is probably responsible for the relatively high concentrations of sodium that were detected in wells in the eastern part of the study area. Although the New York State Department of Health (2008) has no designated limit on the recommended MCL of sodium, they do warn that water containing more than $20 \mathrm{mg} / \mathrm{L}$ of sodium should not be consumed by people on severely restricted sodium diets, and water containing more than $270 \mathrm{mg} / \mathrm{L}$ of sodium should not be consumed by people on moderately restricted sodium diets. The taste threshold (concentration at which the majority of consumers do not notice an adverse taste in drinking water) for sodium ranges from 30 to $60 \mathrm{mg} / \mathrm{L}$ (New York State Department of Health, 2008) and was exceeded in two samples collected from test wells TM994 and TM1967 at the Caroline Elementary School.

The anion that was detected in the greatest concentrations was bicarbonate, while chloride and sulfate generally were detected in lesser concentrations. Bicarbonate values ranged from 89 to $229 \mathrm{mg} / \mathrm{L}$ calcium carbonate (table 4 ) and were calculated from the filtered alkalinity concentrations that ranged from 70 to $188 \mathrm{mg} / \mathrm{L}$ (table 4). Chloride values ranged from 1.18 to $148 \mathrm{mg} / \mathrm{L}$. Sulfate values ranged from 2.06 to $32.2 \mathrm{mg} / \mathrm{L}$ and did not exceed the SMCL of $250 \mathrm{mg} / \mathrm{L}$.

In general, the chemistry of inorganic constituents in the groundwater and surface-water (base-flow) samples is similar (fig. 22), confirming that the surface-water samples that were collected during base-flow conditions were representative of groundwater discharge. There were some exceptions, however, such as sodium and chloride, which were found at elevated concentrations in two wells that were sampled, likely due to discharge of brackish water from underlying bedrock units.

\section{Nutrients}

Groundwater samples collected during the years 2004-05 were analyzed for several nitrogen species; concentrations of nitrate were generally low. In five of the nine samples collected from the valley-fill aquifer, nitrate was below the detection limit of $0.060 \mathrm{mg} / \mathrm{L}$, and the four remaining concentrations ranged from 0.339 to $2.68 \mathrm{mg} / \mathrm{L}$ (table 4); the MCL was not exceeded in any of the samples. Water sampled from well TM1494 (fig. 21), which is finished in the unconfined aquifer in the eastern part of the study area, had the highest nitrate concentration of $2.68 \mathrm{mg} / \mathrm{L}$. Unconfined aquifers are more susceptible to contamination because the chemicals applied on land surface readily seep to the water table where they can easily enter wells. The sampled wells that were finished in confined aquifers had nitrate concentrations that were below the detection limit or less than $0.50 \mathrm{mg} / \mathrm{L}$. Although most water withdrawn from wells is returned to the groundwater through septic systems, most septic effluent probably flows through the shallow groundwater system and eventually discharges to streams rather than making its way to the confined aquifers. The confining units restrict the movement of shallow groundwater, including that which contains effluent from septic systems, from entering the confined aquifer units.

\section{Groundwater Age Dating}

Concentrations of CFCs and ${ }^{3} \mathrm{H}$ can be used to estimate the age of groundwater (table 5). CFCs are synthetic industrial compounds that have been released into the atmosphere since the mid-1940s and are found in precipitation. CFC concentrations in precipitation, and those found in groundwater recently derived from precipitation, correspond to that found in the contemporaneous atmosphere. Atmospheric CFC concentrations have been recorded since about 1945 (Plummer and Busenberg, 2000). Therefore, comparison of CFC concentrations in a water sample to historical records of atmospheric CFC concentrations can indicate the year (post1945 ) in which the water entered the water table. However, the estimated age of a groundwater sample can also reflect mixing of older and younger water within an aquifer.

Recharge temperature is an important component in the interpretation of the age of the water, along with 


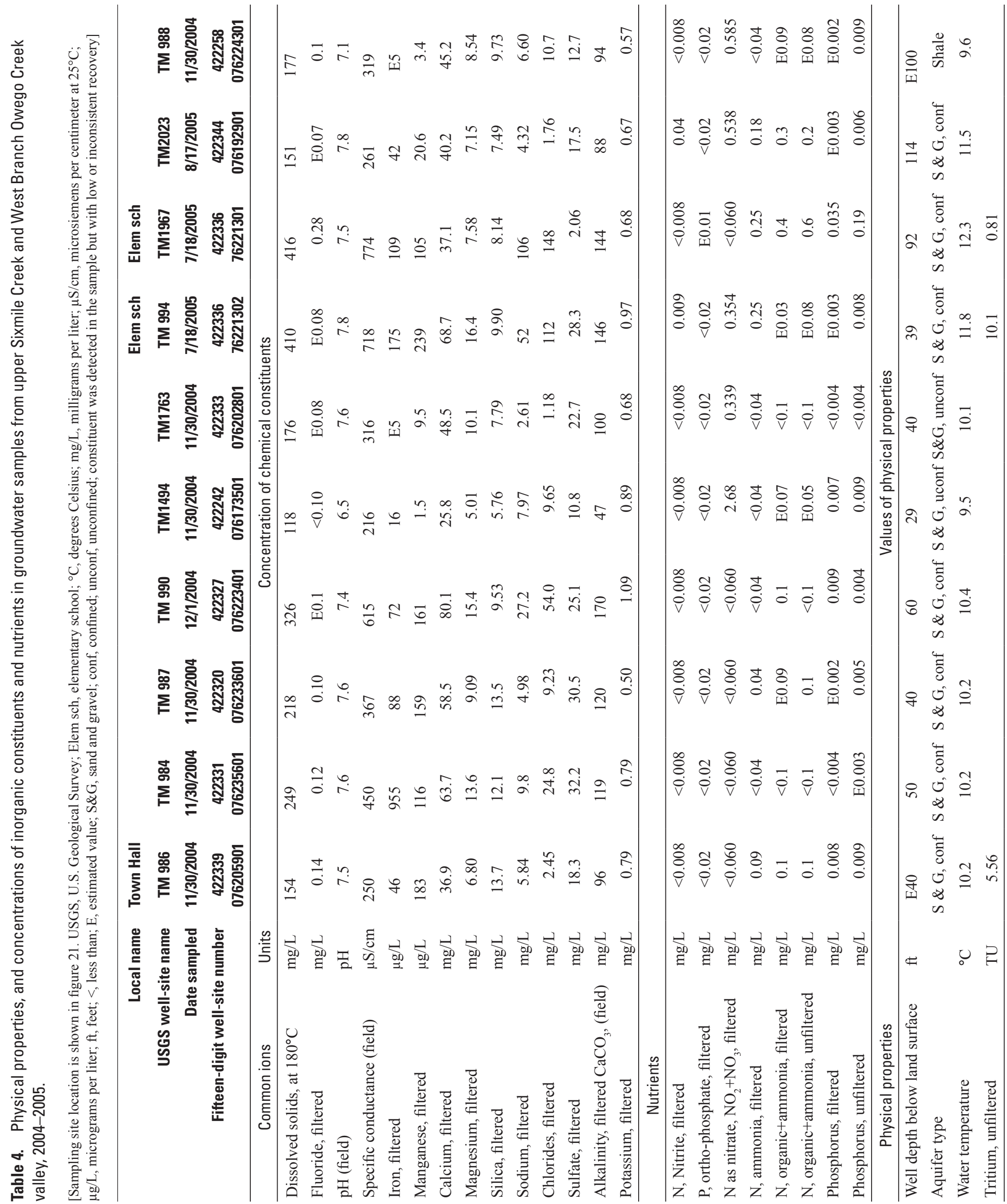


concentrations of CFCs (Heaton, 1981; Heaton and Vogel, 1981; Stute and Schlosser, 1999). The recharge temperatures calculated for water from three wells ranged from 7.1 to $8.2^{\circ} \mathrm{C}$ (table 5).

Tritium $\left({ }^{3} \mathrm{H}\right)$ is a radioactive isotope of hydrogen with a half-life of 12.32 years (Lucas and Unterweger, 2000). Based on releases to the atmosphere from nuclear testing, ${ }^{3} \mathrm{H}$ can be used as a tracer to estimate whether groundwater has been recharged before or after 1953. The standard unit of measure for ${ }^{3} \mathrm{H}$ is a ${ }^{3} \mathrm{H}$ unit (TU) for which $1 \mathrm{TU}$ is equivalent in terms of radioactivity to $3.2 \mathrm{pCi} / \mathrm{L}$ (Clark and Fritz, 1997). The greatest concentrations of ${ }^{3} \mathrm{H}$ (greater than $500 \mathrm{TU}$ ) occurred following periods of atmospheric testing of nuclear weapons that began in 1952 and peaked in 1963-64 (Clark and Fritz, 1997). Atmospheric concentrations have gradually declined since 1963-64 and present-day groundwater typically contains less than 1 to 10 TU (Clark and Fritz, 1997). Natural (prenuclear age) levels of ${ }^{3} \mathrm{H}$ in precipitation are on the order of 1 to 5 TU. The relative age of the groundwater (time since it entered the aquifer and ceased contact with the atmosphere) can be estimated through a comparison of the ${ }^{3} \mathrm{H}$ concentration in a water sample with the recorded historical changes in concentration in the atmosphere, taking into account consideration the half-life decay. Concentrations of ${ }^{3} \mathrm{H}$ in the three groundwater samples ranged from 0.8 to $10.2 \mathrm{TU}$ (table 5). Groundwater that does not contain detectable ${ }^{3} \mathrm{H}$ (less than $0.8 \mathrm{TU}$ ) can be assumed to have been recharged prior to 1953, and groundwater that does contain detectable ${ }^{3} \mathrm{H}$ (more than $0.8 \mathrm{TU}$ ) is assumed to contain some component of groundwater that was recharged after 1953 (Cordy and others, 2000). The ${ }^{3} \mathrm{H}$ concentrations were used along with concentrations of CFCs to estimate the apparent age of groundwater (table 5).
Three samples were collected and analyzed for CFCs, dissolved gases, and ${ }^{3} \mathrm{H}$ to estimate the age of the groundwater in the study area. One sample was collected on November 30, 2004, from the flowing artesian well (TM 986) at the Caroline Town Hall, and two samples were collected on July 18, 2005, at the USGS nested pair of test wells (TM 994 and TM1967) at the Caroline Elementary School (fig. 21). The results of the age-dating samples are given in table 5. The $\mathrm{CFC}$ and ${ }^{3} \mathrm{H}$ samples indicate that the apparent age of the water was early to late 1950 s from the flowing well at the Town Hall, early-to-late 1970s in the shallow test well (39 $\mathrm{ft}$ deep) at the elementary school, and early-to-late 1950s from the deep test well (TM1967) at the elementary school. Relatively low concentrations of CFCs and a low ${ }^{3} \mathrm{H}$ value of $0.8 \mathrm{TU}$ measured in the deep well (TM1967) at the elementary school, as well as relatively high concentrations of sodium and chloride (that are probably derived, for the most part, from brackish water discharging from bedrock into the valley-fill aquifer) indicate that water in the basal confined aquifer is relatively old ( 50 years or more). The water in this well is probably a mixture of older (pre-1950s) bedrock water and some younger (post-1950s) water from recharge that has either travelled through the unconsolidated deposits via long flow paths or moved vertically (extremely slowly) through confining units. Water from the shallow test well (TM 994, finished in the upper confined aquifer) at the elementary school had higher concentrations of CFCs than the deeper test well (TM1967, finished in the basal confined aquifer) at the school, and at the Town Hall well (TM 986, finished in the basal confined aquifer). Also, test well TM 994 had a ${ }^{3} \mathrm{H}$ value of $10.2 \mathrm{TU}$ (table 5 , samples with values between 5 and $15 \mathrm{TU}$ indicate that the water probably entered the aquifer sometime after 1970). Additionally, in well TM 994, analyses

Table 5. Data on apparent groundwater ages from groundwater samples collected from three wells that tap the confined valley-fill aquifers in upper Sixmile Creek valley, Town of Caroline, New York.

[CFC, chlorofluorocarbon, pptv, parts per trillion; ${ }^{3} \mathrm{H}$, tritium; USGS, U.S. Geological Survey]

\begin{tabular}{|c|c|c|c|c|c|c|}
\hline Sample site & $\begin{array}{l}\text { Sampling } \\
\text { date }\end{array}$ & $\begin{array}{c}\text { Calculated } \\
\text { atmospheric } \\
\text { mixing ratio, } \\
\text { pptv, CFC-12 }\end{array}$ & $\begin{array}{c}\text { Model } \\
\text { piston } \\
\text { dates } \\
\text { for CFC-12 }\end{array}$ & $\begin{array}{c}{ }^{3} \mathrm{H} \\
\text { units }\end{array}$ & $\begin{array}{c}\text { Estimated } \\
{ }^{3} \mathrm{H} \\
\text { age }\end{array}$ & Comments \\
\hline TM 986 Caroline Town Hall well & $11 / 30 / 2004$ & $\begin{array}{l}7.31 \\
4.69 \\
6.46\end{array}$ & $\begin{array}{l}1950 \\
1948 \\
1949\end{array}$ & 5.6 & Late $1950 \mathrm{~s}$ & Early to late $1950 \mathrm{~s}$. \\
\hline $\begin{array}{l}\text { TM1967 USGS test well at Caroline } \\
\text { Elementary School }(\text { depth }=92 \mathrm{ft})\end{array}$ & $7 / 18 / 2005$ & $\begin{array}{l}19.83 \\
24.91 \\
22.61\end{array}$ & $\begin{array}{l}1958.5 \\
1960 \\
1959.5\end{array}$ & 0.8 & Early $1950 \mathrm{~s}$ & Early to late $1950 \mathrm{~s}$. \\
\hline
\end{tabular}


showed trace amounts of nitrate and elevated concentrations of sodium and chloride (but only about half that of the deep test well) - all of which suggest that the water from the shallow well TM 994 is a mixture of mostly relatively young water (probably from 1990s and younger) with some older brackish water that is slowly seeping upward from deep zones in the bedrock and through the confining bed that separates the two aquifers. The Caroline Town Hall well (TM 986) had the lowest concentrations of CFCs (table 5) that were analyzed, but it had a higher ${ }^{3} \mathrm{H}$ unit value (5.56 TU) than the deep test well TM1967, which suggests that this water is also a mixture of recent (1952-2003) water and older water (pre-1952).

The results of the apparent ages can be used as clues to determining the sources of recharge to the aquifers. Older water (such as that found in the deep test well TM1967) is indicative of an aquifer that is sealed off from nearby shallow sources of recharge and derives most of its water from either slow infiltration through the overlying confining unit or lateral groundwater inflow from bedrock along the valley walls and valley floor. Conversely, relatively young water (such as that found in well TM 994 finished in the upper confined aquifer) suggests that the sources of recharge are nearby, such as where the confined aquifer crops out at land surface locally along the valley walls.

\section{Summary}

In 2002, the U.S. Geological Survey, in cooperation with the Town of Caroline and Tompkins County Planning Department, began a study of the valley-fill aquifer in upper Sixmile Creek and headwaters of West Branch Owego Creek valleys in the Town of Caroline, NY Confined sand and gravel units form the major aquifers in the western and central portions of the upper Sixmile Creek valley, and an unconfined sand and gravel unit forms the major aquifer in the eastern portion of the upper Sixmile Creek valley and in the headwaters of the West Branch Owego Creek valley.

East-west trending valleys such as upper Sixmile Creek valley that act as tributaries to north-south trending deep troughs (lower Sixmile Creek valley) were not oriented parallel to the direction of ice movement and thus underwent less intensive glacial scouring, which resulted in less deeply eroded valleys than the north-south trending valleys. These east-west trending tributary valleys end high above the floor of the north-south troughs they join and are known as "hanging valleys." The valley-fill deposits thin along the edges of the valley where till-mantled bedrock crops out along the valley walls. The thickness of the valley fill in the thalweg, or deepest part of the valley, is a little over 100 feet (ft) in the west part of the study area and is greater than $165 \mathrm{ft}$ in the central and eastern parts of the valley.

A groundwater divide at the Valley Heads Moraine separates groundwater that flows westward through upper Sixmile Creek valley into the Great Lakes basin from groundwater that flows eastward into the Susquehanna River basin. Groundwater in the upper and basal confined aquifers are under artesian conditions everywhere except at the discharge area in the western end of the upper Sixmile Creek valley where groundwater discharges to springs and to streams. Principal sources of recharge to the two confined aquifers are likely from (1) the side of the valley where the confined aquifers may extend up along the flanks of the bedrock valley walls and crop out at land surface, or are in contact with coarse-grained deltaic and fluvial sediments, both of which constitute an avenue for direct precipitation and seepage losses from tributary streams to recharge the aquifers; or (2) adjacent fine-grained sediment and bedrock where the buried aquifers are isolated from overlying permeable deposits by confining units and receive lesser amounts of recharge.

Most groundwater withdrawals from the valley-fill aquifers are from open-ended, 6-inch-diameter casings, with lesser amounts withdrawn from shallow dug wells and from cisterns that collect groundwater discharged from springs (especially in the Brooktondale, NY, area). The valley-fill aquifer is the source of water for about 200 households, several apartment complexes, two mobile home parks, a school, and several farms and small businesses. About 750 people rely on groundwater from the valley-fill aquifers as a source of drinking water.

In general, the reported yields were somewhat greater for the unconfined sand and gravel aquifer (mean of 18 gallons per minute (gal $/ \mathrm{min}$ ) and median of $15 \mathrm{gal} / \mathrm{min}$ ) than for the confined aquifers (mean of $15 \mathrm{gal} / \mathrm{min}$ and median of 12). Bedrock wells generally had lower yields (mean of $8 \mathrm{gal} / \mathrm{min}$ and median of $6 \mathrm{gal} / \mathrm{min}$ ) than wells finished in the valley-fill aquifers. The respective mean and median well depths for the various aquifer types were: $42 \mathrm{ft}$ and $35 \mathrm{ft}$ for the unconfined sand and gravel aquifer, $64 \mathrm{ft}$ and $57 \mathrm{ft}$ for the confined sand and gravel aquifers, and $149 \mathrm{ft}$ and $135 \mathrm{ft}$ for bedrock aquifers.

During the years 2003-05, 10 surface-water samples were collected at roughly seasonal intervals during base-flow conditions at the U.S. Geological Survey Sixmile Creek at the Brooktondale streamgage site; several samples were also collected from four tributaries in the study area. In the Sixmile Creek samples, the predominant cation detected was calcium, with moderate amounts of magnesium and silica; the major anions were bicarbonate, chloride, and sulfate. Sodium and chloride concentrations were relatively low in all streams sampled but increased downstream in Sixmile Creek. Some of the increase in sodium concentration may be attributed to road salt, but most is likely natural discharge of brackish water originating from deep zones in the bedrock, which discharges upward into the valley-fill aquifers. The concentration of nitrate was less than 1.0 milligram per liter $(\mathrm{mg} / \mathrm{L})$ in all base-flow samples except in the tributary to Sixmile Creek at Slaterville Springs, NY; on July 19, 2005, the concentration was $1.91 \mathrm{mg} / \mathrm{L}$ and on May 5, 2005 the concentration was $1.97 \mathrm{mg} / \mathrm{L}$. During the summer, this tributary originates from groundwater discharging from the Valley Heads Moraine, which is overlain by large amounts of agriculture. 
Groundwater samples were collected from 10 wells, 9 that were finished in sand and gravel aquifers and 1 finished in bedrock. Field measurements were made of $\mathrm{pH}$, specific conductance, dissolved oxygen, and water temperature, and samples were also collected for laboratory analyses of nutrients, common inorganic constituents, and groundwater age dating. Results of the groundwater sample analyses indicate that the water is predominantly a calcium-bicarbonate type. The cation that was detected in the highest concentration was calcium, which ranged from 25.8 to $80.1 \mathrm{mg} / \mathrm{L}$. Sodium values ranged from 2.61 to $106 \mathrm{mg} / \mathrm{L}$, and two samples exceeded the U.S. Environmental Protection Agency Drinking Water Advisory of 30 to $60 \mathrm{mg} / \mathrm{L}$. Sodium concentrations likely varied due to either local enrichment through road de-icing salts or from brackish water in bedrock discharging to the unconsolidated valley fill in some places. Concentrations of nitrate were generally low. In five of the nine samples collected from the valley-fill aquifer, nitrate was below the detection limit of $0.060 \mathrm{mg} / \mathrm{L}$, and concentrations ranged from 0.239 to $2.68 \mathrm{mg} / \mathrm{L}$ in the four wells that were above the detection limit.

Three wells (Caroline Town Hall well TM 986 and two test wells drilled at the Caroline Elementary School, TM 994 and TM1967) were sampled and analyzed for chlorofluorocarbons, dissolved gases, and ${ }^{3} \mathrm{H}$ to estimate the age of groundwater in the study area. The results of the chlorofluorocarbons and ${ }^{3} \mathrm{H}$ sample analyses indicate that the apparent age of the groundwater was early to late 1950s from the flowing well at the Town Hall, early to late 1970s in the shallow test well (39 ft deep) at the elementary school, and early to late 1950s from the deep test well (TM1967) at the elementary school.

\section{References Cited}

Buchanan, T.J., and Somers, W.P., 1982, Stage measurement at gaging stations (Chapter A7): U.S. Geological Survey, Techniques of Water-Resources Investigations of the United States Geological Survey, Book 3, Applications of Hydraulics, $28 \mathrm{p}$.

Busenberg, E., and Plummer, L.N., 1992, Use of chlorofluorocarbons $\left(\mathrm{CCl}_{3} \mathrm{~F}\right.$ and $\left.\mathrm{CCl}_{2} \mathrm{~F}_{2}\right)$ as hydrologic tracers and age-dating tools-The alluvium and terrace system of Central Oklahoma: Water Resources Research, v. 28 , no. 9, p. 2257-2283.

Cadwell, D.H., 1972, Late Wisconsinan deglaciation chronology of the Chenango River valley and vicinity, New York: Binghamton, State University of New York, Ph.D. dissertation, $102 \mathrm{p}$.
Clark, I.D., and Fritz, Peter, 1997, Identifying and dating modern groundwaters, in Clark, I.D., and Fritz, Peter, eds., Environmental isotopes in hydrogeology: New York, Lewis Publishers, p. 172-196.

Clayton, K.M., 1965, Glacial erosion in the Finger Lakes region (New York State, USA): Zeitschrift fur Geomorphologie, NF9, p. 50-62.

Cordy, G.E., Gellenbeck, D.J., Gebler, J.B., Anning, D.W., Coes, A.L., Edmonds, R.J., Rees, J.A.H., and Sanger, H.W., 2000, Water quality in the central Arizona basins, Arizona, 1995-98: U.S. Geological Survey Circular 1213, 38 p.

Cressey, G.B., 1966, Land forms, in Thompson, J.H., ed., Geography of New York State: Syracuse University Press, fig. 9, p. 26.

Fleisher, P.J., 1986, Glacial geology and late Wisconsinan stratigraphy, upper Susquehanna drainage basin, New York, in Cadwell, D.H., ed., The Wisconsinan stage of the First Geological District, eastern New York: New York State Museum Bulletin 455, p. 121-142.

Fleisher, P.J., 1991, Active and stagnant ice retreatDeglaciation of central New York, in Ebert, J.R., ed., Field trip guidebook: Oneonta, State University of New York, New York Geological Association, Department of Earth Sciences, 63rd Annual Meeting, p. 307-371.

Fullerton, D.S., 1980, Preliminary correlation of post-Erie interstadial events $(16,00-10,000)$ radiocarbon years before present), central and eastern Great Lakes region, and Hudson, Champlain, and St. Lawrence lowlands, United States and Canada: U.S. Geological Survey Professional Paper 1089, $52 \mathrm{p}$.

Haeni, F.P., 1988, Application of seismic-refraction techniques to hydrologic studies: U.S. Geological Survey Techniques of Water-Resources Investigations, book 2, chap. D2, 86 p.

Heaton, T.H.E., 1981, Dissolved gases-Some applications to groundwater research: Transactions of the Geological Society of South Africa, v. 84, p. 91-97.

Heaton, T.H.E., and Vogel, J.C., 1981, "Excess air" in groundwater: Journal of Hydrology, v. 50, p. 201-216.

Hutson, S.S., Barber, N.L., Kenny, J.F., Linsey, K.S., Lumia, D.S., and Maupin, M.A., 2000, Estimated use of water in the United States in 2000: U.S. Geological Survey Circular $1268,52 \mathrm{p}$.

Kappel, W.M., and Miller, T.S., 2003, Hydrogeology of the Tully Trough - Southern Onondaga County and northern Cortland County, New York: U.S. Geological Survey Water-Resources Investigations Report 03-4112, 16 p. 
Kappel, W.M., Miller, T.S., and Hetcher, K.K., 2001, Hydrogeology of the Tully Lakes area in southern Onondaga and northern Cortland Counties, New York: U.S. Geological Survey Water-Resources Investigations Report 01-4166, 16 p.

Kennedy, E.J., 1990, Levels at streamflow gages: U.S. Geological Survey Techniques of Water-Resources Investigations, book 3, chap. A19, 39 p.

Kontis, A.L., Randall, A.D., and Mazzaferro, D.L., 2004, Regional hydrology and simulation of flow of stratified-drift aquifers in the glaciated northeastern United States: U.S. Geological Survey Professional Paper 1415-C, 156 p.

Ku, H.F.H., Randall, A.D., and MacNish, R.D., 1975, Streamflow in the New York part of the Susquehanna River basin: New York State Department of Environmental Conservation Bulletin 71, $130 \mathrm{p}$.

Lucas, L.L., and Unterweger, M.P., 2000, Comprehensive review and critical evaluation of the half-life of Tritium: Journal of Research of the National Institute Standards and Technology, v. 105, no. 4, p. 541-C, 549.

MacClintock, Paul, and Apfel, E.T., 1944, Correlation of the drifts of the Salamanca re-entrant, New York: Geological Society America Bulletin, v. 55, p. 1143-1164.

Mickelson, D.M., Clayton, L., Fullerton, D.S., and Borns, H.W., Jr., 1983, The late Wisconsin glacial record in the United States, in Wright, H.E., Jr., ed., Late Quaternary environments of the United States; v. 1, The Late Pleistocene: Minneapolis, University of Minnesota Press, p. 3-37.

Miller, T.S., 2000, Unconsolidated aquifers in Tompkins County, New York: U.S. Geological Survey WaterResources Investigations Report 00-4211, 1 plate.

Miller, T.S., Bugliosi, E.F., Reddy, J.E., 2008, Geohydrology of the unconsolidated valley-fill aquifer in the Meads Creek valley, Schuyler and Steuben Counties, New York: U.S. Geological Survey Scientific Investigations Report 2008-5122, $33 \mathrm{p}$.

Miller, T.S., and Randall, A.D., 1991, Hydrogeology of glacial drift in through valleys near Dryden and Cortland, New York, in Ebert, J.R., ed., Guidebook for field trips, 63rd Annual Meeting, New York Geological Association: Oneonta, State University of New York, p. 463-488.

Miller, T.S., Sherwood, D.A., Jeffers, P.M., and Mueller, Nancy, 1998, Hydrology, water-quality, and simulation of groundwater flow in a glacial aquifer system, Cortland County, New York: U.S. Geological Survey WaterResources Investigations Report 96-4255, 84 p.
Miller, T.S., and Staubitz, W.W., 1985, Hydrogeologic appraisal of five selected aquifers in Erie County, New York: U.S. Geological Survey Water-Resources Investigations Report 84-4334, 89 p.

Muller, E.H., and Cadwell, D.H., 1986, Surficial geologic map of New York, Finger Lakes sheet: New York State Museum and Chart Series 40, scale 1:250,000.

Mullins, H.T., and Hinchey, E.J., 1989, Erosion and infill of New York Finger Lakes-Implications for Laurentide ice sheet deglaciation: Geology, v. 17, p. 622-625.

Neeley, J.A., 1961, Soil survey of Tomkins County, New York: U.S. Department of Agriculture in cooperation with Cornell University Agricultural Experiment Station, Series 1961, no. $25,241 \mathrm{p}$.

New York State Department of Health, 2008, Individual water supply wells-Fact Sheet 3: accessed December 22, 2008, at http://www.health.state.ny.us/environmental/water/ drinking/part5/append5b/fs3_water_quality.htm.

Northeast Regional Climate Center at Cornell University, New York: accessed November 2007, at http://climod.nrcc. cornell.edu.

Olcott, Perry, 1995, Groundwater atlas of the United States, Connecticut, Maine, Massachusetts, New Hampshire, New York, Rhode Island, Vermont: U.S. Geological Survey Hydrologic Atlas 730-M.

Ostlund, H.G., and Werner, E., 1962, The electrolytic enrichment of tritium and deuterium for natural tritium measurements, in Tritium in the physical and biological sciences: Vienna International Atomic Energy Agency, v. 1, p. 95-104.

Piper, A.M., 1944, A graphic procedure in the geochemical interpretation of water analyses: American Geophysical Union Transactions, v. 25, p. 914-923.

Plummer, N.L., and Busenberg E., 2000, Chlorofluorocarbons, in Cook, P.G., and Herczeg, A.L., eds., Environmental tracers in subsurface hydrology: Boston, Kluwer, p. 441-478.

Plummer, L.N., Michael, R.L., Thurman, E.M., and Glynee, P.D., 1993, Environmental tracers for age dating young groundwater, in Alley, W.M., ed., 1993, Regional groundwater quality: New York, Van Nostrand Reinhold, p. 255-294.

Randall, A.D., 1978, Infiltration from tributary streams in the Susquehanna River basin, New York: U.S. Geological Survey Journal of Research, v. 6, no. 3, p. 285-297. 
Randall, A.D., 1981, Hydrology in relation to glacial geology along the Susquehanna River valley, Binghamton to Owego, New York, in Enos, Paul, ed., Guidebook for field trips in south-central New York: Binghamton, New York State Geological Association, 53d Annual Meeting, p. 147-170.

Randall, A.D., 2001, Hydrogeologic framework of stratifieddrift aquifers in the glaciated northeastern United States: U.S. Geological Survey Professional Paper 1415-B, 179 p.

Randall, A.D., Snavely, D.S., Holecek, T.P., and Waller, R.M., 1988, Alternative sources of large seasonal groundwater supplies in the headwaters of the Susquehanna River basin, New York: U.S. Geological Survey Water-Resources Investigations Report 85-4127, 121 p.

Reilly, T.E., Plummer, L.N., Phillips, P.J., and Busenberg, E., 1994, Estimation and corroboration of shallow groundwater flow paths and travel times by environmental tracer and hydraulic analyses-A case study near Locust Grove, Maryland: Water Resources Research, v. 30, no. 2, p. 421-433.

Scott, J.H., Tibbetts, B.L., and Burdick, R.G., 1972, Computer analysis of seismic refraction data: U.S. Bureau of Mines Report of Investigation 7595, 95 p.

Sloto, R.A., and Crouse, M.Y., 1996, HYSEP—A computer program for streamflow hydrograph separation and analysis: U.S. Geological Survey Water-Resources Investigations Report 96-4040, 46 p.

Stute, M., and Schlosser, P., 1999, Atmospheric noble gases, in Cook, P., and Herczeg, A., eds., Environmental tracers in subsurface hydrology: Boston, Kluwer Academic Publishers, chap. 11, p. 349-377.
Stone, B.D., 1995, Progress toward higher resolution of the late Wisconsinan chronology of the New England region, 30 to $13 \mathrm{ka}$ : Geological Society of America, Abstracts with Programs, Northeastern Section, p. 84.

Tarr, R.S., 1905, Drainage patterns of central New York: Geological Society of America Bulletin, v. 16, p. 229-242.

Teller, J.T., 1987, Proglacial lakes and the southern margin of the Laurentide ice sheet, in Ruddiman, W.F., and Wright, H.E., Jr., North America and adjacent oceans during the last deglaciation: Boulder, Colorado, Geological Society of America, The Geology of North America, v. K-3, p. 39-69.

Thatcher, L.L., Janzer, V.J., and Edwards, K.W., 1977, Methods for determination of radioactive substances in water and fluvial sediments: U.S. Geological Survey Techniques of Water-Resources Investigations, book 5, chap. A5, p. 79-81.

U.S. Environmental Protection Agency, 2006, Drinking water standards and health advisories: U.S. Environmental Protection Agency, Office of Water, EPA 822-R-06-013, $12 \mathrm{p}$.

U.S. Geological Survey, variously dated, National field manual for the collection of water-quality data: U.S. Geological Survey Techniques of Water-Resources Investigations, book 9, chaps. A1-A9, available online at http://pubs.water.usgs. gov/twri9A.

U.S. Geological Survey, 2004, CFC web page: accessed October 29, 2003, at http://water.usgs.gov/lab/cfc

U.S. Geological Survey, 2009, New York annual water-data report 2006, in New York annual reports: U.S. Geological Survey web page accessed January 8, 2009, at http:// ny.water.usgs.gov/htmls/pub/data.html. 


\section{Appendix 1}

Records of selected wells in upper Sixmile Creek valley and part of West Branch Owego Creek valley, Town of Caroline, New York. 


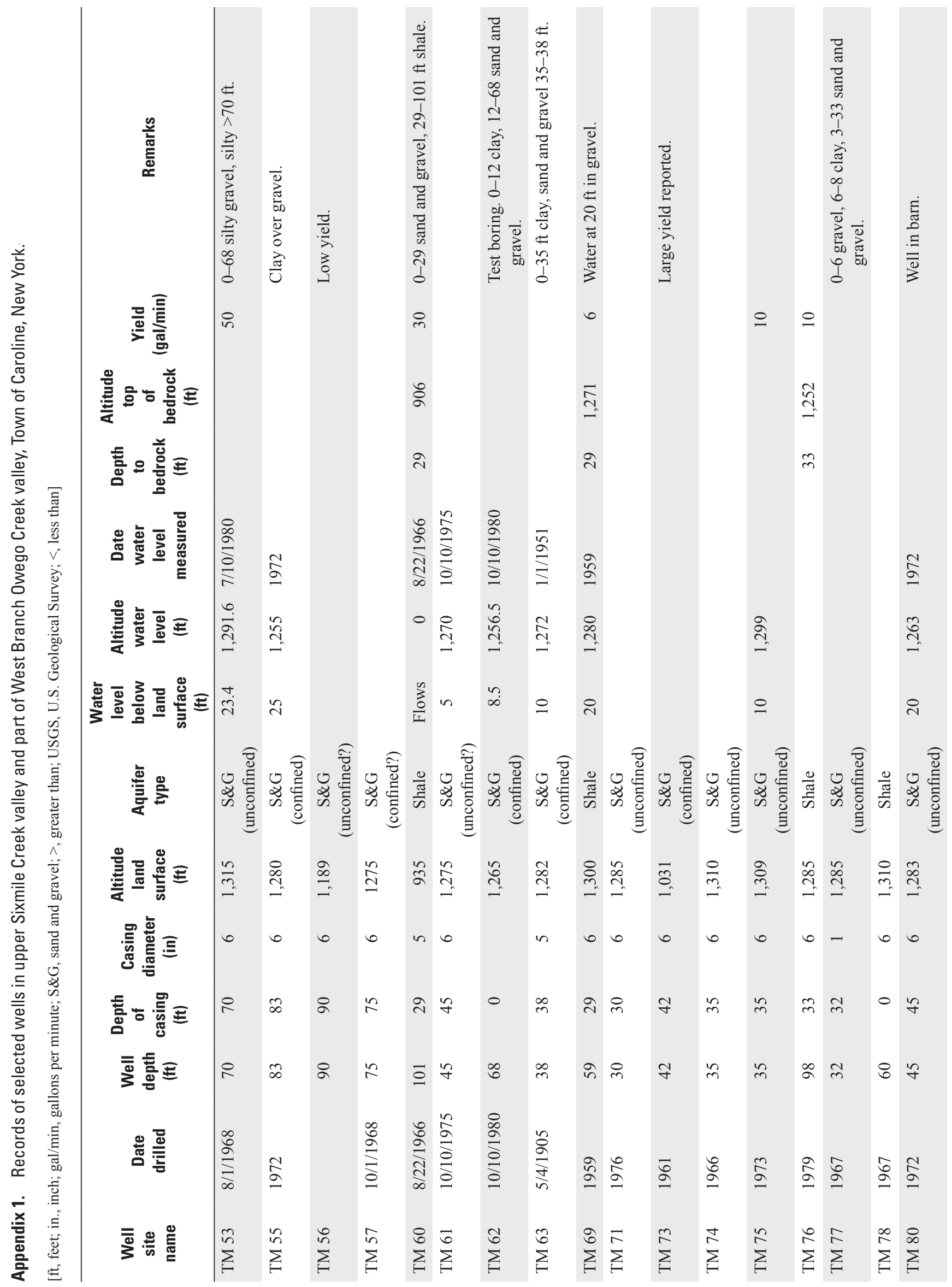




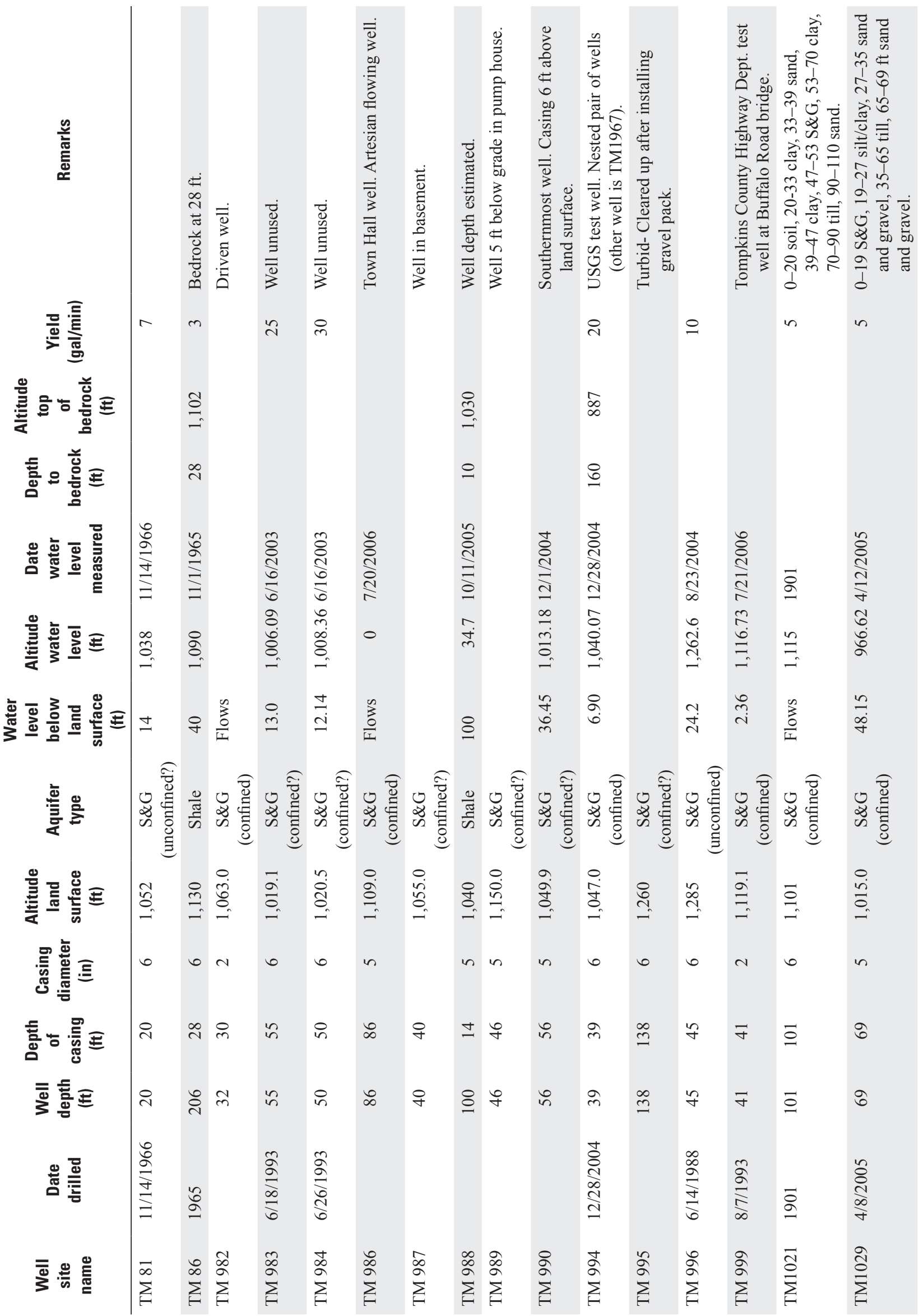




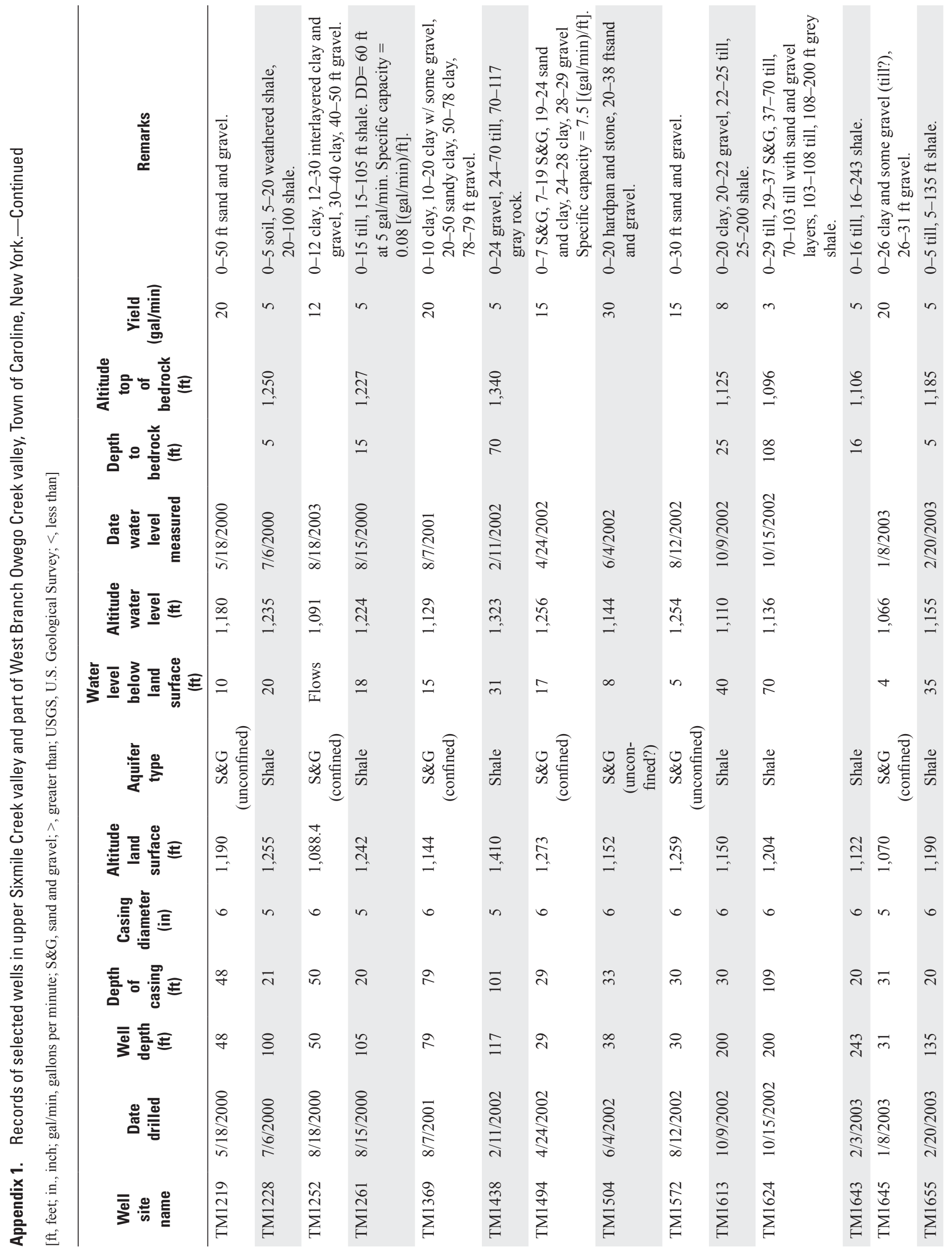




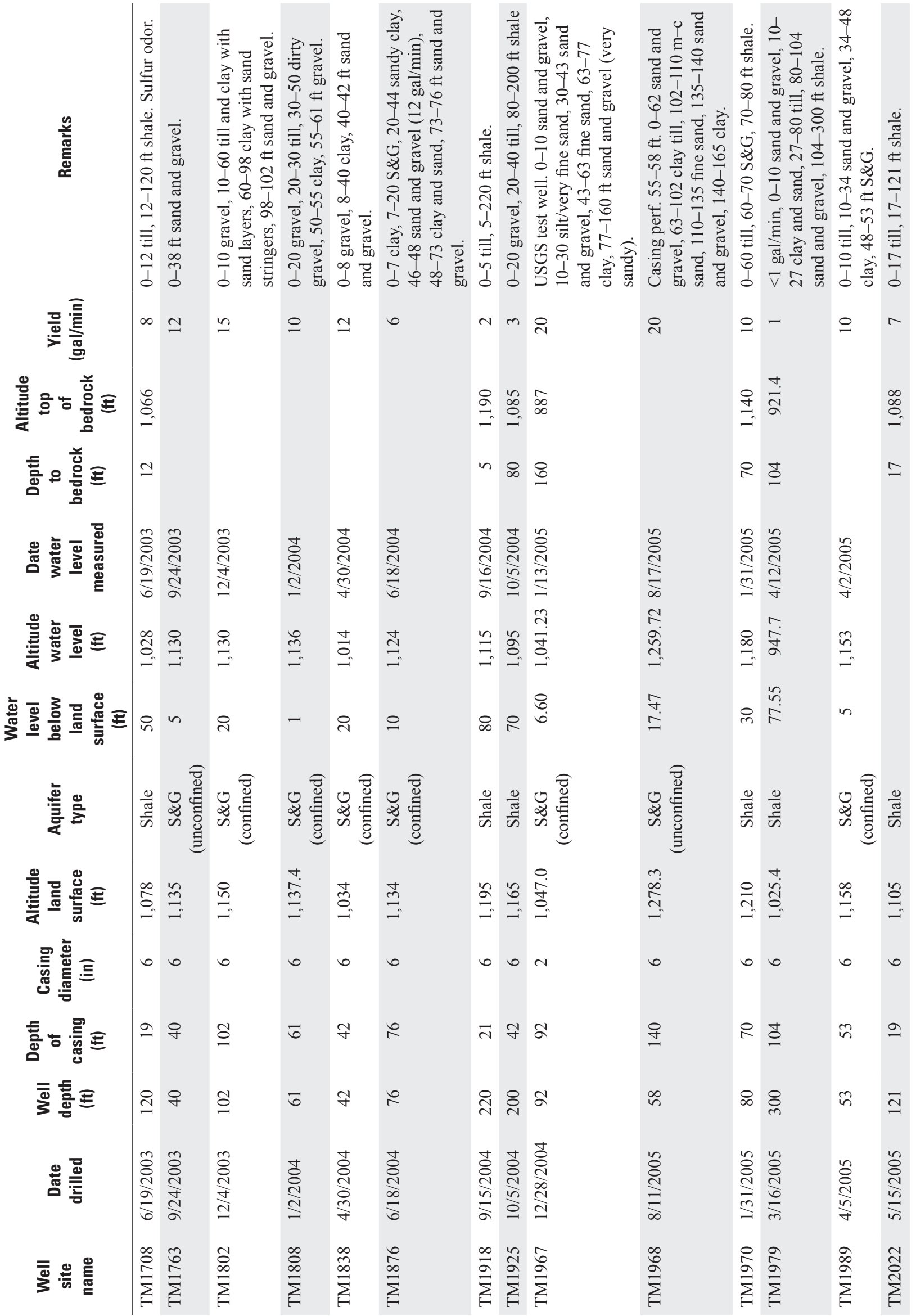




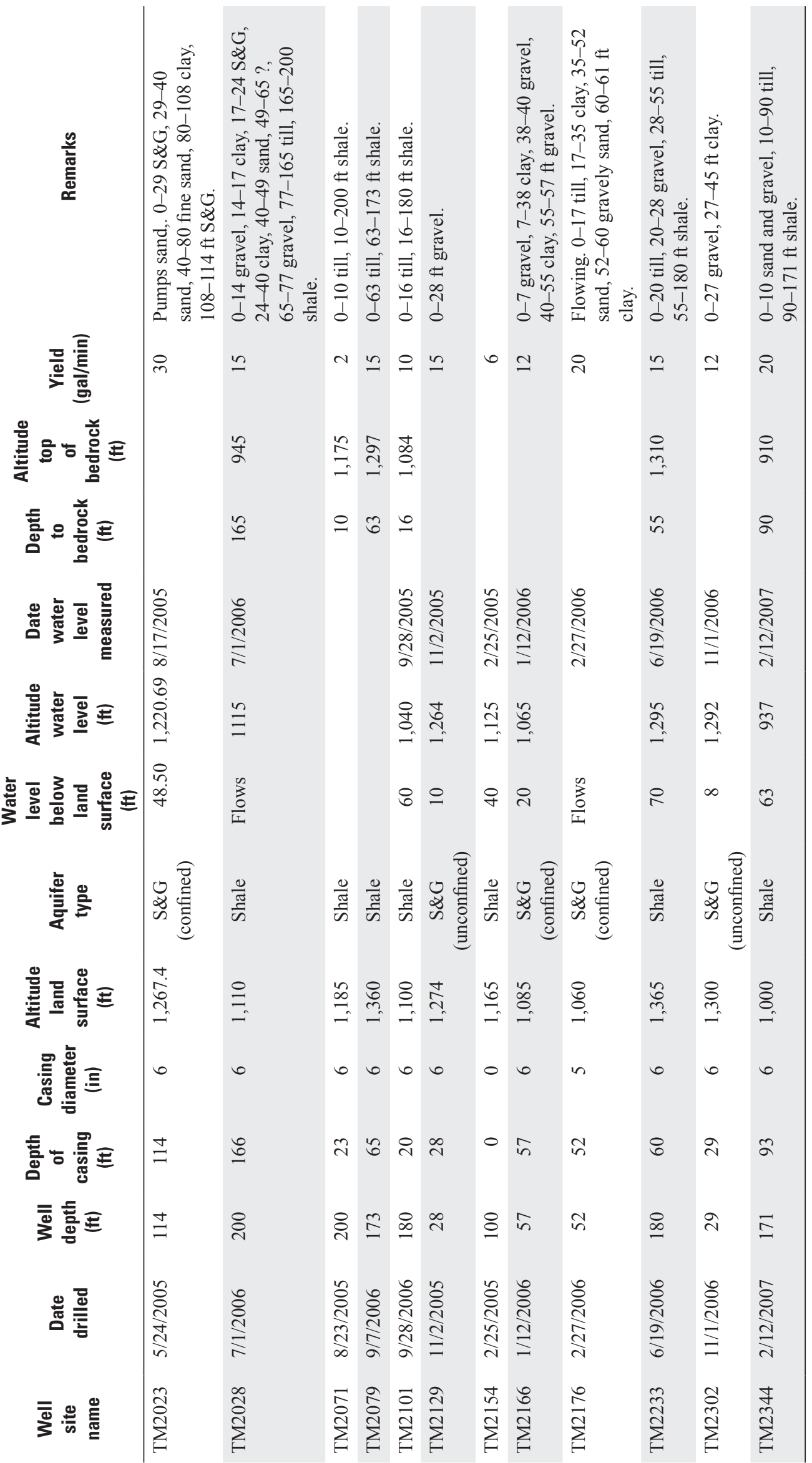


Prepared by the Pembroke Publishing Service Center and the West Trenton Publishing Service Center

For additional information write to:

New York Water Science Center

U.S. Geological Survey

425 Jordan Road

Troy, NY 12180

Information requests:

(518) 285-5602

or visit our Web site at: http://ny.water.usgs.gov 


\section{$\frac{1}{8}$}

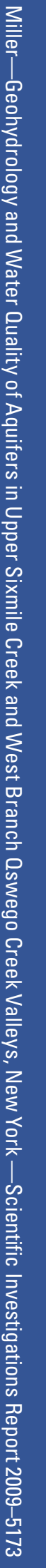

Printed on recycled paper

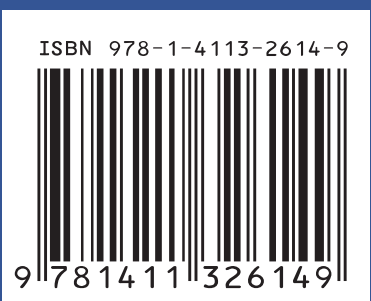

